\title{
VEGETATION MAPPING AND ESTIMATION OF THE EXTENT OF NEAR-SURFACE PERMAFROST IN THE MACKENZIE DELTA, NORTHWEST TERRITORIES
}

\author{
by \\ Thai-Nguyen Nguyen, B.Eng., B.A. (Hons.)
}

\begin{abstract}
A thesis submitted to
the Faculty of Graduate Studies and Research

in partial fulfillment of the requirements of the degree of
\end{abstract}

Master of Science

Department of Geography and Environmental Studies

Carleton University

Ottawa, Ontario

September 2007

(C) Thai-Nguyen Nguyen 2007 


$\begin{array}{ll}\begin{array}{l}\text { Library and } \\ \text { Archives Canada }\end{array} & \begin{array}{l}\text { Bibliothèque et } \\ \text { Archives Canada }\end{array} \\ \begin{array}{l}\text { Published Heritage } \\ \text { Branch }\end{array} & \begin{array}{l}\text { Direction du } \\ \text { Patrimoine de l'édition }\end{array} \\ \begin{array}{l}\text { 395 Wellington Street } \\ \text { Ottawa ON K1A ON4 }\end{array} & \begin{array}{l}\text { 395, rue Wellington } \\ \text { Ottawa ON K1A ON4 } \\ \text { Canada }\end{array}\end{array}$

Your file Votre référence ISBN: 978-0-494-33708-0 Our file Notre référence ISBN: 978-0-494-33708-0

NOTICE:

The author has granted a nonexclusive license allowing Library and Archives Canada to reproduce, publish, archive, preserve, conserve, communicate to the public by telecommunication or on the Internet, loan, distribute and sell theses worldwide, for commercial or noncommercial purposes, in microform, paper, electronic and/or any other formats.

The author retains copyright ownership and moral rights in this thesis. Neither the thesis nor substantial extracts from it may be printed or otherwise reproduced without the author's permission.
AVIS:

L'auteur a accordé une licence non exclusive permettant à la Bibliothèque et Archives Canada de reproduire, publier, archiver, sauvegarder, conserver, transmettre au public par télécommunication ou par l'Internet, prêter, distribuer et vendre des thèses partout dans le monde, à des fins commerciales ou autres, sur support microforme, papier, électronique et/ou autres formats.

L'auteur conserve la propriété du droit d'auteur et des droits moraux qui protège cette thèse. $\mathrm{Ni}$ la thèse ni des extraits substantiels de celle-ci ne doivent être imprimés ou autrement reproduits sans son autorisation.
In compliance with the Canadian

Privacy Act some supporting forms may have been removed from this thesis.

While these forms may be included in the document page count, their removal does not represent any loss of content from the thesis.
Conformément à la loi canadienne sur la protection de la vie privée, quelques formulaires secondaires ont été enlevés de cette thèse.

Bien que ces formulaires aient inclus dans la pagination, il n'y aura aucun contenu manquant.

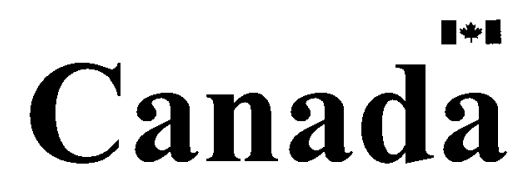




\begin{abstract}
This study investigates the proportion of the Mackenzie Delta, Northwest Territories, underlain by near-surface permafrost. The objectives were to assess if the distribution of vegetation can be used to predict permafrost presence and, if so, to determine the proper remote sensing techniques that can be applied to map these vegetation communities with SPOT-5 images. The resulting maps could then be used to estimate the extent of near-surface permafrost.

On point bars and on alluvial islands, Horsetail zones in the southern and central delta as well as Willow-horsetail communities in all three delta regions were associated with absence of permafrost in the upper $3 \mathrm{~m}$. Permafrost was present beneath all other vegetation associations as well as at other geomorphic locations. NDVI and MSAVI as well as texture information were found to be useful for discriminating between vegetation communities. Three classifiers were tested: Maximum Likelihood (ML), Artificial Neural Networks (ANN), and Linear Spectral Unmixing (LSU). ML achieved the highest overall accuracies of $84.2 \%, 82.4 \%$, and $83.4 \%$ for the southern, central, and northern delta image, respectively. LSU was useful in studying vegetation gradation from one community to another. Zones with presence of near-surface permafrost occupy $91 \%$, $95 \%$, and $96 \%$ of the land surface, in the southern, central, and northern delta, respectively. This indicates that the Mackenzie Delta is part of the continuous permafrost zone. The permafrost classification resulting from this research is in agreement with classifications based on climate data from Brown (1967, 1973). However, it differs with the classification from Heginbottom et al. (1995), based on ground temperature data, categorizing the Delta as having discontinuous permafrost.
\end{abstract}




\section{ACKNOWLEDGEMENTS}

This thesis would not have been possible without the supervision of Dr. Chris Burn and Dr. Doug King. Dr. Chris Burn's passion for the Canadian North and his enthusiasm in the field was a great inspiration. Dr. Chris Burn and Dr. Doug King's guidance and encouragement throughout this thesis were greatly appreciated. I am also thankful to Dr. Sharon Smith of the Geological Survey of Canada in Ottawa and Dr. Steve Kokelj of Indian and Northern Affairs Canada in Yellowknife for their support and thought-provoking comments.

Funding for this research was provided by a Natural Sciences and Engineering Research Council (NSERC) PGS scholarship as well as by an Earth Sciences Sector Postgraduate Scholarship Supplement of the Geological Survey of Canada. The field season was funded by the Northern Scientific Training Program, the Polar Continental Shelf Project, Dr. Chris Burn's NSERC Northern Research Chair program, and a grant from Dr. Steve Kokelj. Dr. Doug King's Canadian Foundation for Innovation grant also gave me the opportunity to work in the state-of-the-art Geomatics and Landscape Ecology Research Laboratory.

Many people assisted in the field component of this project. First, I would like to thank my colleague Julian Kanigan for his support and his sharing of ideas. Having a friend in the field was certainly a great luck for me. Julian's insights on relationships with First Nations as a Northerner were also priceless. I am grateful to Douglas Esagok, Larry Greenland, and William Hurst from Inuvik for their hard work and sharing of Inuvialuit and Gwich'in ways of life. I will always treasure the memories of my visit to Douglas' 
family whaling camp on Kendall Island, of Larry's wind-fence made from willows when we were stranded on Middle Channel, and of William's extraordinary ptarmigan hunting skills. Les Kutny, Greg King, and Melaika Soule also brave the Mackenzie Delta bugs to help with data collection. The success of the 2006 field season was also due in part to Dr. Steve Kokelj, Peter Morse, and Mike Palmer who helped me develop my fieldwork skills during my first stay in the Delta in summer 2005.

Thanks to Laura Dingle-Robertson and Jonathan Pasher for helping me navigating through the quirks of PCI Geomatica. At Carleton, I would also like to thank Quang Ngo for assisting me with field logistics and providing me the most reliable goosers, and Dr. Scott Mitchell for his explanations on the mysteries of spatial autocorrelation.

Lastly and most importantly, thanks so much for the indefectible love and support of my husband and best friend Cong-Khanh Dinh. Thank you for being patient and understanding at difficult times. Your enduring interest in my work and your affection were truly invaluable. 
$\begin{array}{ll}\text { Abstract } & \text { ii }\end{array}$

Acknowledgements $\quad$ iii

Table of Contents $\quad \mathrm{v}$

List of Figures $\quad$ xi

List of Tables $\quad$ xiii

CHAPTER ONE: OVERVIEW AND OBJECTIVES 1

1.1 Introduction 1

1.2 Spatial distribution of permafrost 3

1.3 Remote sensing of permafrost conditions 4

1.4 Research objectives 5

1.5 Thesis structure 5

CHAPTER TWO: VARIABLES CONTROLLING THE SPATIAL 6 DISTRIBUTION OF PERMAFROST AND REMOTE SENSING OF PERMAFROST

$\begin{array}{lll}2.1 & \text { Introduction } & 6\end{array}$

2.2 Variables controlling the spatial distribution of permafrost 6

2.2.1 Air temperature $\quad 6$

$\begin{array}{ll}2.2 .2 \text { Snow cover } & 10\end{array}$

$\begin{array}{lll}2.2 .3 & \text { Vegetation } & 10\end{array}$

$\begin{array}{lll}2.2 .4 & \text { Hydrology } & 14\end{array}$ 
$\begin{array}{lll}2.2 .5 & \text { Topography } & 16\end{array}$

$\begin{array}{ll}\text { 2.2.6 Ground materials } & 17\end{array}$

$\begin{array}{lll}2.3 & \text { Remote sensing } & 18\end{array}$

$\begin{array}{lll}\text { 2.3.1 Spatial, spectral, and temporal resolution } & 18\end{array}$

$\begin{array}{ll}\text { 2.3.2 Image data transformations } & 21\end{array}$

2.3.2.1 Vegetation indices $\quad 21$

2.3.2.2 Texture analysis $\quad 23$

2.3.2.3 Principal component analysis $\quad 24$

$\begin{array}{lll}\text { 2.3.3 Image classification } & 25\end{array}$

$\begin{array}{ll}\text { 2.3.3.1 Classification stages } & 25\end{array}$

$\begin{array}{ll}\text { 2.3.3.2 Parametric supervised classifications } & 25\end{array}$

2.3.3.3 Non-parametric supervised classifications $\quad 26$

$\begin{array}{ll}\text { 2.3.3.4 Soft classifications } & 28\end{array}$

$\begin{array}{ll}\text { 2.3.4 Accuracy assessment of classified maps } & 30\end{array}$

2.3.5 Remote sensing of permafrost conditions 31

$\begin{array}{ll}\text { 2.3.6 Concluding remarks } & 32\end{array}$

CHAPTER THREE： FIELDWORK IN THE MACKENZIE DELTA 33

$\begin{array}{lll}3.1 & \text { Introduction } & 33\end{array}$

3.2 Environmental conditions in the Mackenzie Delta 33

3.2.1 Location and geomorphic setting 33

$\begin{array}{lll}3.2 .2 & \text { Climate } & 35\end{array}$

vi 
3.2.3 Hydrologic regime 36

$\begin{array}{lll}\text { 3.2.4 Vegetation communities } & 37\end{array}$

$\begin{array}{lll}\text { 3.2.5 Permafrost } & 40\end{array}$

3.2.6 Subsurface conditions 44

$\begin{array}{lll}3.3 & \text { Study site selection } & 44\end{array}$

$\begin{array}{lll}\text { 3.3.1 Delta regions } & 44\end{array}$

$\begin{array}{lll}\text { 3.3.2 Site selection } & 45\end{array}$

$\begin{array}{lll}3.4 & \text { Field methods } & 47\end{array}$

$\begin{array}{lll}3.4 .1 & \text { Sampling window } & 47\end{array}$

$\begin{array}{lll}3.4 .2 & \text { Vegetation sampling } & 47\end{array}$

3.4.2.1 Herb layer measurements $\quad 47$

3.4.2.2 Shrub and tree layer measurements $\quad 54$

3.4.2.3 Leaf-area index measurements $\quad 54$

3.4.3 Near-surface permafrost probing $\quad 55$

3.4.4 Ground control points $\quad 56$

3.4.5 The water-land boundary issue 56

$\begin{array}{ll}3.5 & \text { Concluding remarks } \\ \end{array}$

CHAPTER FOUR: VEGETATION AND NEAR-SURFACE PERMAFROST 59

$\begin{array}{llr}4.1 & \text { Introduction } & 59\end{array}$

$\begin{array}{ll}\text { 4.2 Physical characteristics of study sites } & 59\end{array}$

$\begin{array}{lll}\text { 4.2.1 } & \text { Southern delta } & 59\end{array}$

$\begin{array}{lll}\text { 4.2.2 Central delta } & 61\end{array}$

vii 
$\begin{array}{lll}\text { 4.3 Shoreline variations during summer } 2006 & 63\end{array}$

$\begin{array}{lll}4.4 & \text { Vegetation composition and structure } & 64\end{array}$

$\begin{array}{lll}\text { 4.4.1 Horsetail community } & 69\end{array}$

$\begin{array}{lll}\text { 4.4.2 Willow-horsetail community } & 69\end{array}$

$\begin{array}{lll}\text { 4.4.3 Alder community } & 73\end{array}$

$\begin{array}{lll}\text { 4.4.4 Willow-bearberry community } & 74\end{array}$

$\begin{array}{ll}\text { 4.4.5 Sedge community } & 74\end{array}$

$\begin{array}{lll}\text { 4.4.6 Short willow community } & 75\end{array}$

$\begin{array}{lll}\text { 4.4.7 Spruce forests } & 76\end{array}$

$\begin{array}{lll}4.5 & \text { Leaf-area index } & 76\end{array}$

4.6 Relation between vegetation and presence of near-surface permafrost 81

$\begin{array}{lll}4.7 & \text { Concluding remarks } & 84\end{array}$

CHAPTER FIVE: IMAGE DATA ANALYSIS METHODS 87

$\begin{array}{lll}5.1 & \text { Introduction } & 87\end{array}$

$\begin{array}{lll}5.2 & \text { SPOT-5 data acquisition } & 87\end{array}$

$\begin{array}{lll}5.3 & \text { Image georeferencing } & 87\end{array}$

5.4 Determination of the extent of alluvial islands in the southern delta 91

$\begin{array}{ll}\text { 5.5 Image data transformations } & 91\end{array}$

$\begin{array}{lll}\text { 5.5.1 Atmospheric correction } & 91\end{array}$

$\begin{array}{ll}\text { 5.5.2 Principal component analysis } & 92\end{array}$

$\begin{array}{lll}\text { 5.5.3 Texture analysis } & 92\end{array}$

viii 
5.5.4 Vegetation indices

5.6 Vegetation communities' classification 94

5.6.1 Selection of training and testing data 94

5.6.2 Separability analysis 95

5.6.3 Maximum likelihood classification $\quad 96$

$\begin{array}{lll}\text { 5.6.4 Neural network classifications } & 96\end{array}$

$\begin{array}{lll}\text { 5.6.5 Linear spectral unmixing } & 97\end{array}$

CHAPTER SIX: $\quad$ IMAGE DATA ANALYSIS RESULTS AND 99

ESTIMATION OF NEAR-SURFACE

PERMAFROST EXTENT

$\begin{array}{lll}6.1 & \text { Introduction } & 99\end{array}$

$\begin{array}{lll}6.2 & \text { Principal component analyses } & 99\end{array}$

$\begin{array}{lll}6.3 & \text { Separability analyses } & 103\end{array}$

6.3.1 Initial class merging using spectral bands and components $\quad 103$

6.3.2 Determination of the best texture components 105

6.3.3 Determination of the best vegetation index 105

$\begin{array}{lll}6.4 & \text { Classification analyses } & 108\end{array}$

6.4.1 Maximum likelihood classifications 108

$\begin{array}{ll}\text { 6.4.1.1 Southern delta } & 108\end{array}$

$\begin{array}{ll}\text { 6.4.1.2 Central delta } & 112\end{array}$

$\begin{array}{ll}\text { 6.4.1.3 Northern delta } & 113\end{array}$

$\begin{array}{ll}\text { 6.4.2 Artificial neural network classifications } & 119\end{array}$

ix 
6.4.3 Factors influencing classification accuracy

6.4.4 Linear spectral unmixing

6.5 Estimation of near-surface permafrost extent

6.6 Summary of classification results

7.1 Summary of results

7.1.1 Vegetation and near-surface permafrost on point bars and alluvial islands

7.1.2 Remote sensing of vegetation communities

7.2 Conclusions

7.3 Limitations of this research and recommendations for future research

REFERENCES 


\section{LIST OF FIGURES}

1.1 Map of Mackenzie Delta 2

2.1 Distribution of permafrost in Canada ( $4^{\text {th }}$ edition of the Atlas of Canada) 8

2.2 Mean annual air temperature (MAAT) and mean annual near-surface 9 ground temperature (MAGT) for the Mackenzie valley region

2.3 Ground-temperature profiles at four sites with different vegetation 13 in the northern Mackenzie Delta

$\begin{array}{ll}2.4 & \text { Ground temperatures and permafrost configuration in the }\end{array}$ Mackenzie Delta

2.5 Artificial neural network applied to classification of remote sensing data 27

3.1 Photograph taken over the southwestern delta 34

3.2 Plant succession showing flood tolerance groups on point bars 38 in the southern and central delta

3.3 Typical vegetation communities in the Delta 39

3.4 Mackenzie Delta classified as having discontinuous permafrost $\quad 41$ ( $5^{\text {th }}$ edition of the Atlas of Canada)

3.5 Presence of a talik near shorelines on point bars 43

3.6 Identification of field transects 46

$\begin{array}{lll}3.7 & \text { Transect locations in the northern delta } & 48\end{array}$

3.8 Transect locations in the central delta 49

$\begin{array}{ll}3.9 & \text { Transect locations in the southern delta } \\ \end{array}$

3.10 Near-surface permafrost probing and vegetation sampling protocols 51 $\mathrm{xi}$ 
$\begin{array}{ll}4.1 & \text { Photograph of SD17 }\end{array}$

$\begin{array}{lll}4.2 & \text { Photograph of SD11 }\end{array}$

$\begin{array}{lll}4.3 & \text { Shoreline variation at SD13 } & 65\end{array}$

$\begin{array}{lll}4.4 & \text { Ground and canopy cover in the southern delta } & 70\end{array}$

$\begin{array}{ll}\text { 4.5 Ground and canopy cover in the central delta } & 71\end{array}$

4.6 Ground and canopy cover in the northern delta 72

$\begin{array}{lll}\text { 4.7 Short willow community } & 77\end{array}$

$\begin{array}{lll}4.8 & \text { Box-and-whisker plots for LAI } & 78\end{array}$

$\begin{array}{lll}5.1 & \text { Image data analysis steps } & 88\end{array}$

$\begin{array}{lll}5.2 & \text { SPOT-5 MS images of the study areas } & 89\end{array}$

$\begin{array}{lll}6.1 & \text { Principal component analysis } & 101\end{array}$

6.2 The southern delta classified using the best MLC results 111

6.3 The central delta classified using the best MLC results $\quad 114$

6.4 The northern delta classified using the best MLC results 115

$\begin{array}{ll}\text { 6.5 Fraction images from linear spectral unmixing } & 124\end{array}$

6.6 SD3 transect of vegetation fraction image proportion showing $\quad 125$ the relation between image values and classified vegetation zones 


\section{LIST OF TABLES}

2.1 Spectral and spatial characteristics of common optical satellite sensors $\quad 19$

4.1 Vegetation composition and structure in the southern delta 66

4.2 Vegetation composition and structure in the central delta 67

4.3 Vegetation composition and structure in the northern delta 68

4.4 Summary of pairwise comparisons of LAI between 80 vegetation associations

4.5 Relation between vegetation associations and presence of 82 near-surface permafrost in the southern delta

4.6 Relation between vegetation associations and presence of 82 near-surface permafrost in the central delta

4.7 Relation between vegetation associations and presence of 83 near-surface permafrost in the northern delta

4.8 Relation between presence of near-surface permafrost and 85 vegetation association with drilled holes grouped by vegetation association and by delta region

5.1 Correlation matrix showing $\mathrm{r}$ values for SPOT-5 spectral bands 93

$\begin{array}{lll}\text { 6.1 PCA of spectral data } & 100\end{array}$

$\begin{array}{lll}6.2 & \text { Southern delta: Separability analyses } & 104\end{array}$

$\begin{array}{lll}6.3 & \text { Central delta: Separability analyses } & 104\end{array}$

6.4 Northern delta: Separability analyses $\quad 104$

$\begin{array}{ll}\text { 6.5 Highest ranking texture components } & 106\end{array}$ xiii 
6.6 Variable combinations used in separability analyses to determine the most appropriate vegetation index

6.7 Error matrix for the PC1-4 + PC TEX classification of the southern delta 109

6.8 Error matrix for the SWIR + Green + PC_TEX + MSAVI 109 classification of the central delta

6.9 Error matrix for the SWIR + PC1 + PC_TEX + NDVI classification of the northern delta

6.10 Tested neural network configurations for the southern delta image

6.11 Tested neural network configurations for the central delta image 118

6.12 Tested neural network configurations for the northern delta image $\quad 119$

6.13 Producer and user accuracies for the best ANN tested for each image $\quad 120$

6.14 Area underlain by near-surface permafrost for each delta region 127

6.15 Extent of near-surface permafrost using percentages of positive drilled holes of Table 4.8 


\section{CHAPTER ONE}

\section{OVERVIEW AND OBJECTIVES}

\subsection{Introduction}

This thesis investigates the proportion of the Mackenzie Delta, Northwest Territories (Fig. 1.1), underlain by near-surface permafrost. Permafrost is ground that remains at or below $0{ }^{\circ} \mathrm{C}$ for at least two consecutive years (van Everdingen 1998), and underlies about $40 \%$ of the ground surface of Canada (Kettles et al. 1997). Near-surface permafrost is defined in this thesis as permafrost within $3 \mathrm{~m}$ from ground surface. Above the permafrost is the active layer, a zone that freezes in winter and thaws in summer. Permafrost is a key component of northern environmental systems because it influences terrain stability (Lewkowicz and Harris 2005), surface hydrology (Carey and Woo 1999), geochemical cycling (Kokelj and Burn 2005a), and vegetation distribution and growth (Gill 1973). In addition, permafrost has always had significant effects on the economic development of the North, particularly for the energy and mining industries, but also for infrastructures such as roads, railways and utilities (Smith et al. 2001).

Four main permafrost zones have been delineated in the Northern Hemisphere (Heginbottom et al. 1995): (1) a zone of continuous permafrost, where permafrost underlies more than $90 \%$ of the exposed ground i.e. ground not covered by rivers and lakes; (2) a zone of discontinuous permafrost, where $50-90 \%$ of the exposed ground is underlain by permafrost; (3) a zone of sporadic permafrost, with $10-50 \%$ of the exposed ground underlain by permafrost; and (4) a zone of isolated patches of permafrost, where less than $10 \%$ of the area, largely limited to organic terrain, is underlain by permafrost. In 


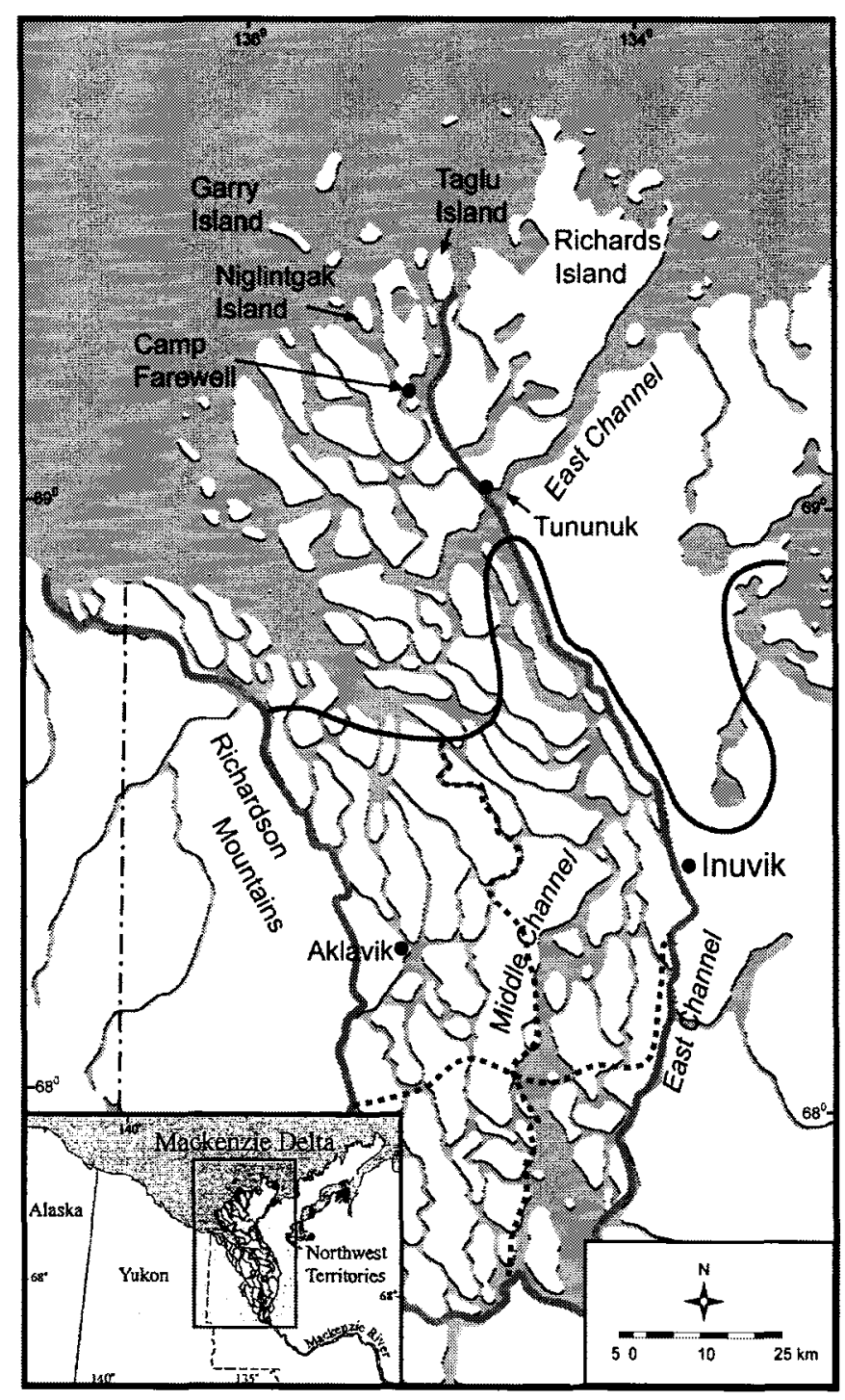

Fig. 1.1 - The Mackenzie Delta (boundary in blue) is the largest delta in Canada. Tree line (in red) crosses the delta and marks the transition from boreal forest to shrubby vegetation. The five sub-regions of the Delta are defined by the red dashed lines. The northern delta is demarcated by tree line, and the boundary between the central and southern delta is based on levee heights approximated by Mackay (1963). Tree line is also from Mackay (1963) and has not moved substantially during the $20^{\text {th }}$ century in northwestern Canada (Timoney et al. 1992). 
addition, there are zones of subsea permafrost in ocean sediments, and alpine permafrost at high altitudes in mountainous environments.

Climatically, permafrost should be continuous in the Mackenzie Delta (Brown 1967, 1973), and its presence is widely reported (Smith 1975; Kokelj and Burn 2004). However, the most recent permafrost map in the Atlas of Canada, classifies the Delta as having discontinuous permafrost although little fieldwork investigating permafrost extent quantitatively and covering the several regions of the delta has occurred. Ground temperature measurements, with which permafrost mapping could be done via interpolation of data points, have been collected in the Delta over the last 35 years. However, the majority of these measurements were clustered in accessible areas of the central-eastern region, near Inuvik, and in areas of the north-eastern Delta related to hydrocarbon exploration (Smith et al. 2005). The Delta is a complex and dynamic environment where flooding and channel shifting present challenges in terms of permafrost conditions. The distinction between continuous and discontinuous permafrost is important for land use regulation, as terrain behaviour and authorized practice varies between frozen and unfrozen ground. The focus of this thesis is on near-surface permafrost due to its direct influence on infrastructure and land use.

\subsection{Spatial distribution of permafrost}

Climate is the main factor determining the continental distribution of permafrost, and commonly there is an increase of permafrost spatial occurrence with increasing latitude. However, site-specific factors, such as snow, vegetation, hydrology, topography, 
and subsurface conditions, interact to buffer the effects of climate on the ground thermal regime and locally control the spatial distribution of permafrost (Smith 1975).

In the Mackenzie Delta, taliks have been recognized near channels by various authors (Gill 1973; Smith 1975, 1976). The presence of a talik where winter freeze-back does not reach the top of permafrost is due to the slow establishment of permafrost beneath newly exposed point bars, and to deep snow drifts blown by the wind off the channels and trapped in near-shore shrubs (Gill 1973; Dyke 2000a).

\subsection{Remote sensing of permafrost conditions}

Permafrost cannot be directly imaged by airborne or satellite-based sensors, but its presence may be inferred from surface characteristics, especially vegetation (Duguay et al. 2005). Remote sensing can provide land cover information over vast areas and is more practical than a full ground survey for spatially extensive vegetation mapping. However, in some regions, undetectable variations in subsurface properties may prevent permafrost mapping by interpretation of remotely sensed imagery (Leverington and Duguay 1997). In the Mackenzie Delta, subsurface materials are relatively consistent, so the ground thermal regime may be more easily associated with specific vegetation communities (Mackay 1963; Johnston and Brown 1965; Gill 1972). In this thesis, SPOT5 images of the Mackenzie Delta, acquired in 2006, are interpreted for vegetation characteristics associated with near-surface permafrost. Using relations of these characteristics with field survey data acquired between June and August 2006, the proportion of ground underlain by near-surface permafrost is estimated. 


\section{$1.4 \quad$ Research objectives}

The objectives of this research are:

1. To assess if the spatial distribution of vegetation associations can be used to predict near-surface permafrost presence in the Mackenzie Delta;

2. If so, to determine the most appropriate remote sensing techniques that can be used to map vegetation communities and to estimate the proportion of ground underlain by near-surface permafrost.

\subsection{Thesis structure}

This thesis is composed of seven chapters. The next chapter discusses the variables controlling the spatial distribution of permafrost as well as various image classification methods pertinent to this research. Chapter Three describes environmental conditions in the Mackenzie Delta, and the field methods used. Chapter Four examines the relations between vegetation associations and the presence of near-surface permafrost at study sites. Chapter Five discusses remote sensing techniques used for vegetation mapping of the Delta. Chapter Six examines how vegetation mapped utilizing remotely sensed data can facilitate predictions of near-surface permafrost presence in the Delta. Chapter Seven summarizes the results of this thesis, presents conclusions, and recommends opportunities for future research. 
CHAPTER TWO

VARIABLES CONTROLLING THE SPATIAL DISTRIBUTION OF

PERMAFROST AND REMOTE SENSING OF PERMAFROST

\subsection{Introduction}

The main variables that control the spatial distribution of permafrost are: air temperature, snow cover, vegetation, hydrology, topography, and ground materials (Ferrians and Hobson 1973). Site-specific surface and subsurface conditions interact to buffer the effects of climate on the ground thermal regime and locally control the spatial distribution of permafrost.

Although permafrost cannot be directly imaged by remote sensing, surface conditions can be used to infer permafrost distribution. Remote sensing can provide land cover information over vast areas and can be used to extrapolate results of field surveys. Also, remotely sensed images provide a visual archive of temporal change that is not readily obtainable from field surveys. These capabilities are especially important in remote environments which are costly and difficult to access (Duguay et al. 2005).

\subsection{Variables controlling the spatial distribution of permafrost}

\subsubsection{Air temperature}

Air temperature is the main factor determining the continental distribution of permafrost, commonly resulting in an increase of permafrost spatial occurrence and thickness with increasing latitude. The effect of latitude on permafrost distribution operates through its influence on the incoming flux of solar radiation, and, consequently, 
the energy balance at the ground surface (Zhang et al. 1999). Permafrost can occur wherever the mean annual ground temperature is below $0{ }^{\circ} \mathrm{C}$. Brown $(1967,1973)$ used the $-5{ }^{\circ} \mathrm{C}$ mean annual ground temperature to delimit the region of continuous permafrost (Fig. 2.1). The mean annual ground temperature was approximated to be up to $6{ }^{\circ} \mathrm{C}$ higher than the mean annual air temperature (Fig. 2.2). At its southern limit, permafrost can occur in scattered patches a few centimetres thick, usually in association with peat bogs (Vitt and Halsey 1994). In the far north, permafrost is ubiquitous and can reach a thickness of over 600 metres (Smith et al. 2001). The influence of past climates may also be preserved in permafrost by ground temperatures, which have yet to reach equilibrium with the present climate (Halsey et al. 1995).

In northern Canada, two broad climate zones, defined in terms of air temperature, can be found: the Arctic and the Subarctic. These zones can be further divided into subcategories such as High Arctic, Low Arctic, High Subarctic, and Low Subarctic. The southern limit of the subarctic zone has been defined as where mean annual air temperature is below $0{ }^{\circ} \mathrm{C}$ (Rouse 1993). Isotherms of mean annual air temperature deviate from the parallels of latitude due to a number of factors, including the elevation of the Cordillera, which acts as a barrier to Pacific maritime influences, the pattern of the westerlies, and the seasonal changes of ice cover in the Arctic Ocean and Hudson Bay. Winter isotherms display a strong southeasterly trend, from the western arctic coast to the west coast of Hudson Bay, and then a northeasterly trend to the Labrador-Ungava coast. The same trend is also developed in summer because of the long-lived sea-ice along the western and southern coasts of Hudson Bay. This isotherm trend helps explain the continental distribution of continuous and discontinuous permafrost (Rouse 1993). 


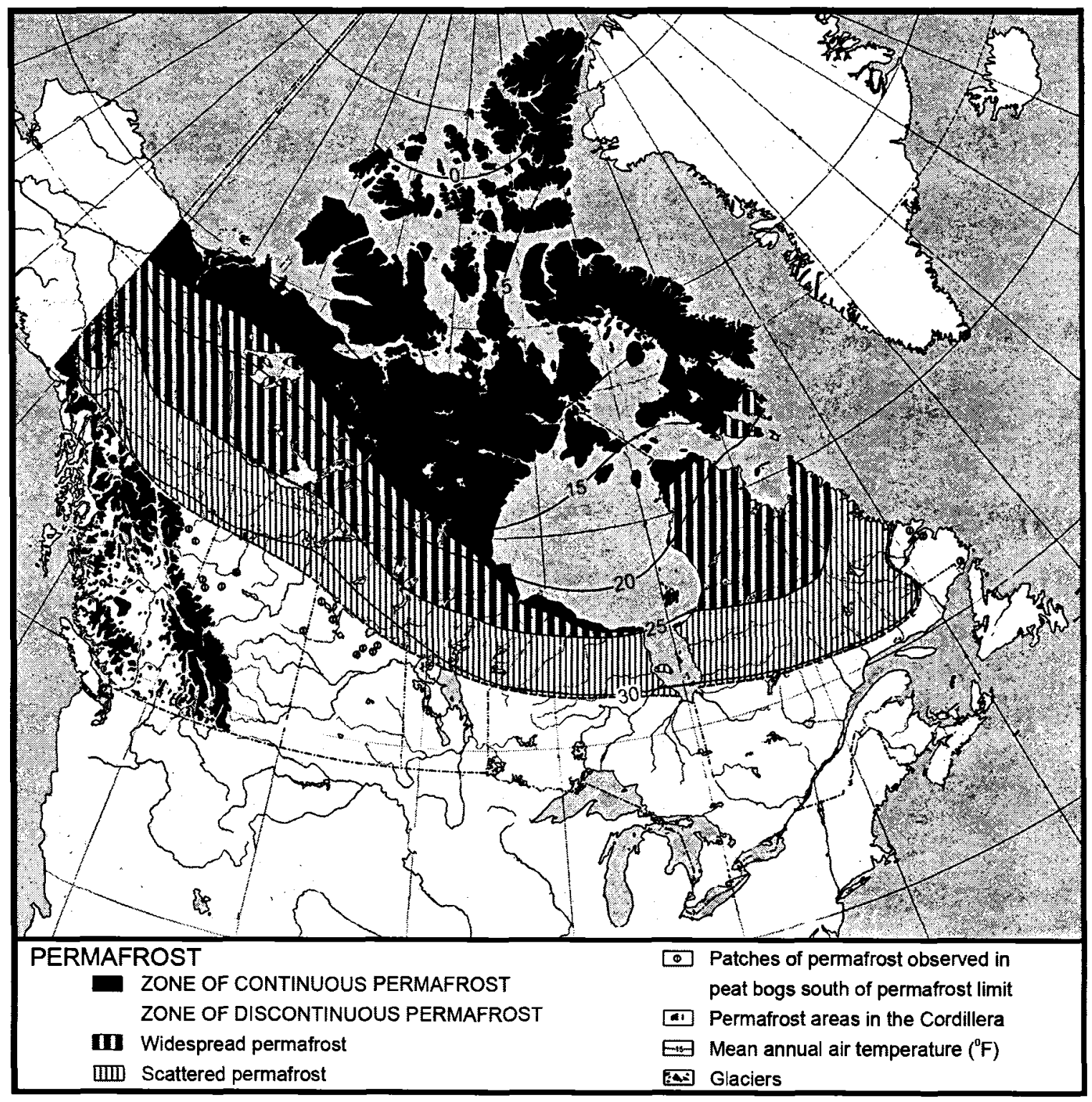

Fig. 2.1 - Mean annual air temperature and permafrost distribution in Canada in the $4^{\text {th }}$ edition of the Atlas of Canada. The southern limit of permafrost shown on the map coincides approximately with the $-1{ }^{\circ} \mathrm{C}\left(30^{\circ} \mathrm{F}\right)$ mean annual isotherm of air temperature (adapted from Brown 1973). 


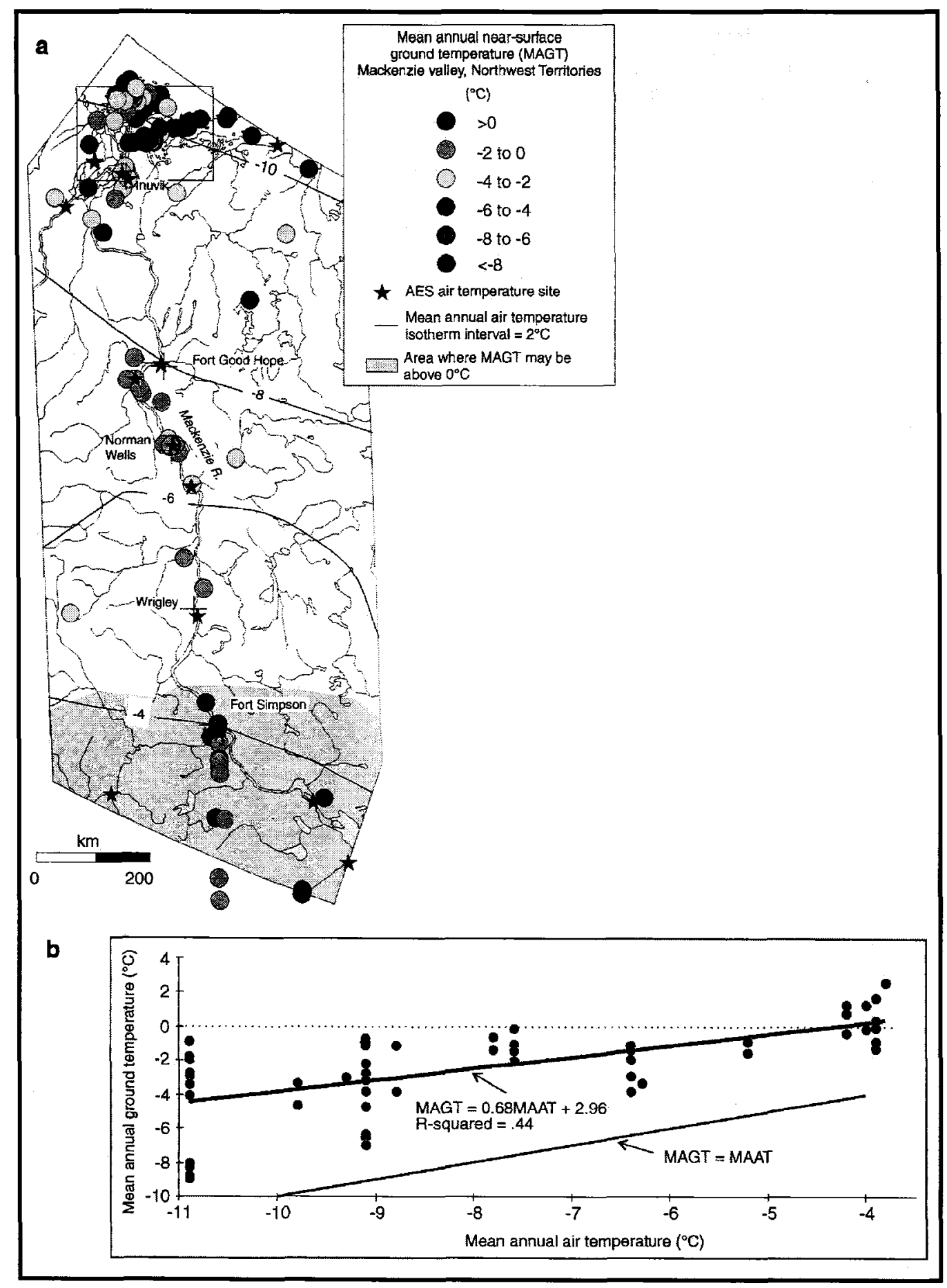

Fig. 2.2 - a) Mean annual air temperature (MAAT) and mean annual near-surface ground temperature (MAGT) for the Mackenzie valley region. b) Relation between MAAT and MAGT (Burgess and Smith 2000, Fig. 3). 


\subsubsection{Snow cover}

At the continental scale, ground temperatures and permafrost distribution are well correlated with air temperatures. However, at a local scale, factors such as snow cover become more significant. Increased snow cover has been determined to be the cause of thickening of the active layer (Mackay and Burn 2002) and permafrost degradation (Smith 1975). Due to its low thermal conductivity, snow cover has an important role in retarding heat loss from the ground (Mackay and MacKay 1974; Goodrich 1982) and can be a factor controlling the presence of permafrost (Granberg 1973). Snow cover provides effective insulation to the ground, particularly when it is loosely packed and deep (Sturm et al. 2001). In contrast, the melting of a deep snow cover can reduce summer ground temperatures by increasing the soil moisture content.

In addition, snow increases surface albedo, leading to a reduction in the amount of shortwave radiation absorbed at the surface. Furthermore, the timing of the snow-covered period affects the ground thermal regime. An early winter snow cover will reduce frost penetration, while a persistent spring snow cover will delay ground thaw (Brown and Péwé 1973). Therefore, microclimates produced by varied snow covers lead to different surface offsets, which are the difference between the annual mean temperature at the ground surface and the annual mean air temperature (Eaton et al. 2001). These microclimates also produce spatial disparities in permafrost distribution.

\subsubsection{Vegetation}

Vegetation zones are typically associated with climatic zones; arctic vegetation is characteristically tundra, which grades southwards across the tree line into the boreal 
forest of the subarctic zone. Vegetation type can be a good indicator of the spatial distribution of permafrost since permafrost acts as an impervious ground mass through which roots and water can seldom penetrate. Most hydrologic activities are confined above ground or in the moist to saturated active layer, which supplies summer moisture to plants and the evaporative flux (Hinzman et al. 2005). The local predominance of certain tree and shrub species at sites in a region underlain by discontinuous permafrost can be a strong indicator of the specific presence of permafrost and of the thickness of the active layer. Generally, shallow-rooted coniferous species such as white spruce (Picea glauca) tend to be dominant in regions characterized by thin active layers (Leverington 1995). Deep-rooted, deciduous tree species tend to be found in areas without permafrost or with relatively thick active layers. Dense willow stands, with adventitious roots, can be found in areas unfrozen to even greater depths and are commonly indicative of watersaturated soils and a high sedimentation regime (Gill 1973).

The role of vegetation as a ground insulator and moderator of snow cover has been recognized by various studies (Brown and Péwé 1973). In summer, vegetation has a cooling effect by shading the ground from solar radiation, and promoting evaporation. In contrast, tall and dense trees can inhibit the transfer of heat from the ground to the air when the ground heat flux is directed towards the atmosphere by slowing air currents (Brown 1966). In winter, coniferous vegetation can intercept snowfall and, reduce snow depth leading to lower ground temperatures. In contrast, leafless deciduous vegetation can allow a more even throughfall of snow while reducing effects of wind drifts with a resulting light and deep snow cover. In addition, vegetation belts near exposed land can be responsible for deep snowpacks since they can trap large accumulations of blowing 
snow, resulting in permafrost degradation (Smith 1975). The snow retention capacity of vegetation is positively related to vegetation structure, which includes height, stem diameter and density, and canopy density (Fig. 2.3) (Burgess and Smith 2000). A surrogate summary variable for vegetation density is the one-sided leaf area index (LAI), which is the ratio of the foliage area to the ground area (Riedel et al. 2005).

Ground-surface vegetation, particularly lichens, mosses and peat, also have an insulating effect on underlying ground (Brown 1966). Dry peat has a low thermal conductivity during the warm summer period, limiting the transfer of heat to the ground below. However, wet and frozen peat have much higher thermal conductivities during the cool fall and winter periods, allowing for the rapid loss of heat from the ground to the atmosphere. A thick organic layer has been found to promote lower ground temperatures and to maintain permafrost (Williams and Burn 1996; Burgess and Smith 2000). In the discontinuous permafrost zone, permafrost formed under a favourable climate can survive under warmer climatic conditions as long as it remains protected by ecosystems properties (Shur and Jorgenson 2007). For example, thin permafrost that formed in the peatlands of central Canada during the Little Ice Age (circa 1450-1850) has persisted through the last century due to the thermal properties of peat and the presence of excess ice (Halsey et al. 1995). Smith et al. (2005) also show that over the last 20 years there has been very little change in ground temperature of warm permafrost (near $0^{\circ} \mathrm{C}$ ) at a peatland site in northern Alberta, illustrating the insulating effect of peat. Shur and Jorgenson (2007) called this permafrost "climate-driven, ecosystem-protected". In contrast, removal of the organic layer, by forest fires for instance, results in higher ground temperatures and a deepening of the active layer (Mackay 1995; Burn 1998). 


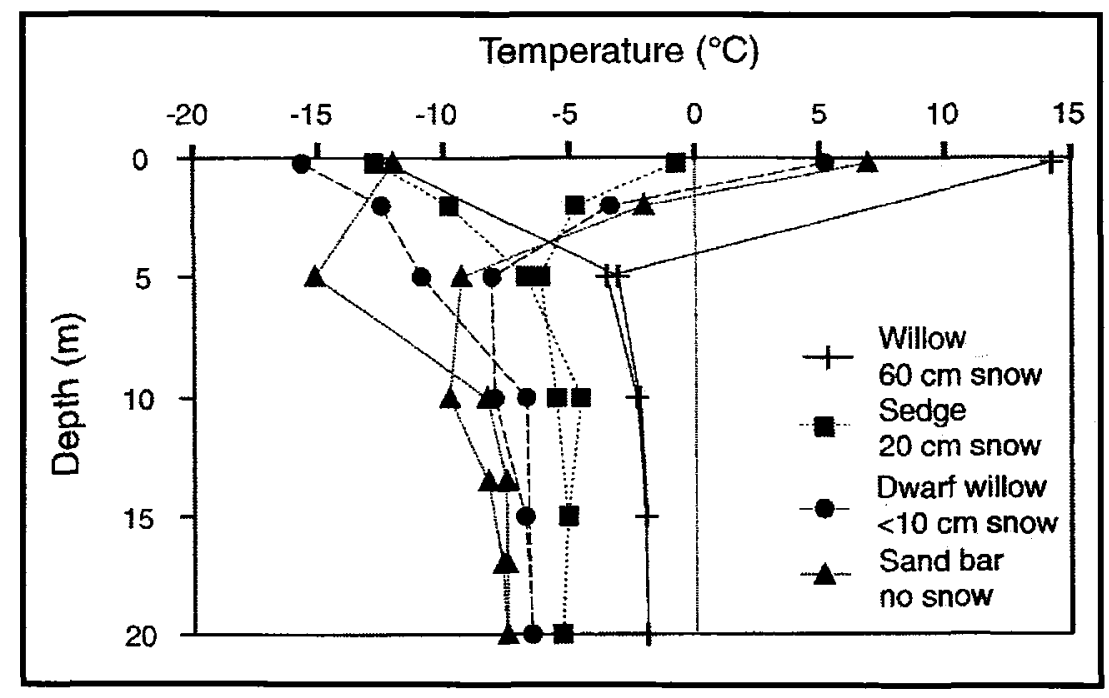

Fig. 2.3 - Ground-temperature profiles at four sites with different vegetation in the northern Mackenzie Delta, N.W.T. Snow depths vary from willows, trapping $60 \mathrm{~cm}$ of snow, to an unvegetated sand bar kept clear of snow by the wind. The insulating effect of the snow also reduces the maximum depth of annual temperature variation. Dates of the temperature profiles are March and July 1992 (Burgess and Smith 2000, Fig. 12). 


\subsubsection{Hydrology}

Water has a high heat capacity and, therefore, large water bodies acting as a heat source have a significant impact on nearby permafrost temperatures. Mackay (1962) pointed out that when rivers or lakes are deep enough to exceed the ice thickness, the subjacent sediments remain above $0{ }^{0} \mathrm{C}$ due to the thermal influence of water. The occurrence of this unfrozen ground or talik, surrounded by permafrost, constitutes a local departure of ground temperature from systematic patterns dictated by climate. In permafrost regions, shorelines produce the most abrupt contrasts in ground temperature. The extent of the temperature disturbance depends on the water body area, shape, depth, bottom configuration, water temperature and past thermal history (Johnston and Brown 1964). The influence of water bodies on ground temperatures in the western Arctic has been investigated in several studies (e.g. Mackay 1962; Burn 2002a). Smith (1976) also calculated ground temperatures and permafrost configuration within an area of the Mackenzie Delta (Fig. 2.4): in this example, permafrost shows an abruptly dipping surface at the edge of the river and the large lake, and an hour-glass-shaped talik underneath the small lake.

Shorelines change position because of erosion, sedimentation or sea-level change. The consequence of channel migration is to carry the river heat source across frozen ground and hence upset the thermal equilibrium beneath land and water (Dyke 2000a). Moving water is an efficient thawing and erosive agent, especially in regions of high ground-ice content (Brown and Péwé 1973; Viereck 1973). In addition, the subwater talik follows channel migration across the land surface (Smith and Hwang 1973). Lake drainage and river shifting may also expose unfrozen sediments, previously located 


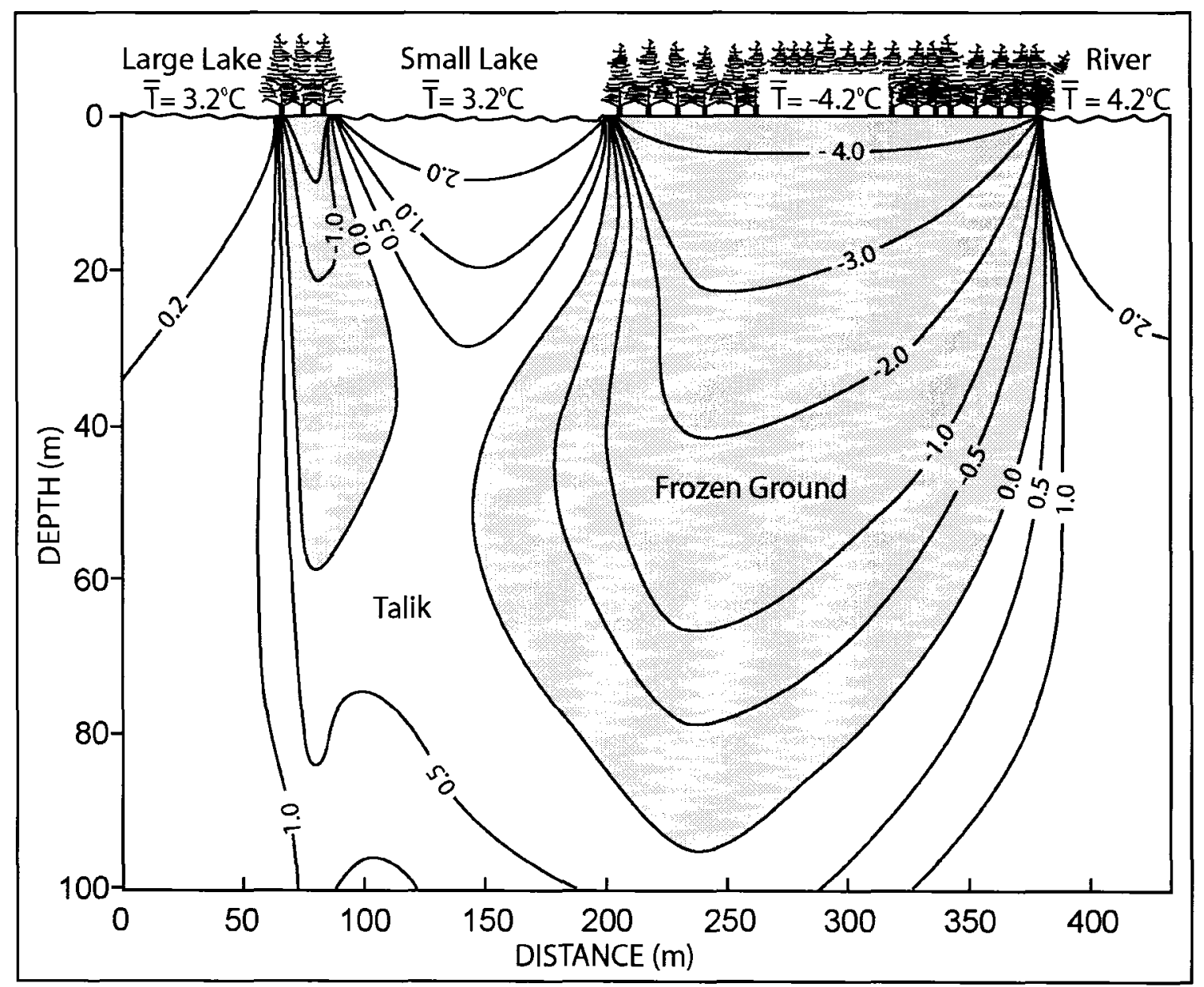

Fig. 2.4 - Calculated temperatures and permafrost configuration based on values for the mean annual lake, river, and ground surface temperatures. Permafrost shows a vertical surface at the edge of the river and the large lake (adapted from Smith 1976, Fig. 14). 
beneath water bodies, to freezing air temperatures, leading to ground cooling and the growth of permafrost (Smith 1976; Mackay 1986). Contemporary permafrost formation in the continuous permafrost zone is controlled by climate and this permafrost type is classified as "climate-driven" by Shur and Jorgenson (2007). Thus, the local spatial distribution of permafrost can be closely related to the history of river migration nearby.

\subsubsection{Topography}

The main topographic factors influencing permafrost occurrence are elevation, slope, and aspect. Alpine permafrost may exist at high elevation at latitudes where it is not otherwise present because of the decrease in air temperature with elevation (Williams and Smith 1989). For example, in Canada, alpine permafrost can be found in the western Cordillera, and $100000 \mathrm{~km}^{2}$ of permafrost exists in the high plateaus and high mountains of the western United States from Washington to Arizona (Péwé 1983).

The degree and orientation of a slope can also affect permafrost distribution through the energy balance of the ground by controlling the amount of solar radiation received (Ferrians and Hobson 1973). Thus south-facing slopes with more direct exposure to incident solar radiation are occasionally unfrozen, while proximal northfacing slopes are underlain by permafrost such as the case of the Wolf Creek basin in the discontinuous permafrost zone of southern Yukon (Lewkowicz and Ednie 2004). The basal temperature of snow (BTS) method used in conjunction with topography as well as snow depth has proven to be a useful tool in order to determine permafrost distribution in mountainous areas in Canada (Lewkowicz and Ednie 2004). 


\subsubsection{Ground materials}

Ground materials also have an influence on permafrost occurrence (Burgess and Smith 2000). Dissimilar ground materials have different thermal conductivities, which affect the ground thermal regime by controlling the rate of heat loss. Karunaratne and Burn (2004) demonstrated that subsurface conditions can be a controlling factor of the ground thermal regime since a range of ground surface temperatures were found at sites in central Yukon with similar air temperatures and snow covers.

The thermal conductivity of the ground is affected by soil texture, mineral composition, bulk density and water content. At the same water content, sandy soil has five times the thermal conductivity of peat soil, which has twice the porosity (Williams and Smith 1989). Regardless of the type of soil, thermal conductivity increases with water content. The soil's heat capacity, the amount of heat energy required to raise the temperature of a unit volume of soil by $1{ }^{\circ} \mathrm{C}$, is also controlled by soil texture, mineral composition, bulk density, and water content. Fine-textured soil, such as clay, has higher volumetric heat capacity than coarse sandy soil. The volumetric heat capacity of soil rises in a linear fashion with water content (Williams and Smith 1989).

Ground materials also affect drainage and, consequently, soil water content. Coarse-textured soils, such as sands, are usually well drained, while fine-textured soils, such as silt and clay, tend to be poorly drained. Permafrost studies in Alaska demonstrated that the active layer is thicker in well-drained sandy soils than in poorlydrained fine-grained materials (Nelson et al. 1997). Poorly-drained soils tend to be cooler than proximal well-drained soils because a greater part of the incoming heat energy is used for evaporation of soil water rather than for warming the ground. Poor drainage can 
be a cause or a consequence of permafrost since permafrost has low permeability. Luthin and Guymon (1974) showed that there could be a positive feedback where a high frost table hampers drainage, which further promotes the preservation of permafrost.

\subsection{Remote sensing}

\subsubsection{Spatial, spectral, and temporal resolution}

Remote sensing is the science of acquiring information about the Earth's surface without being in contact with it. This is done by recording reflected or emitted spectral electromagnetic radiation, and analyzing and classifying that information. Optical satellite sensors, operating in the 400-2500 $\mathrm{nm}$ spectrum, are often employed for studying various surface characteristics. A review of satellite remote sensing of wetlands found that it could be difficult to identify different vegetation communities from one another because of the overlap in their spectral signatures and the spatial resolution of most satellite sensors (Ozesmi and Bauer 2002). But, compared to aerial photography, using satellite remotely sensed data for land cover classification is less costly and less timeconsuming for large geographic areas. Table 2.1 highlights spectral and spatial resolutions of a few common optical satellite sensors that have been proven useful in identifying different terrain types including vegetation communities.

Active radar sensors transmit and receive radiation in the microwave portion of the spectrum. Compared to optical sensors, radar systems have the advantage of being able to acquire data at any time of day and under cloudy conditions. Radar can also detect wetness and roughness related to vegetation structure (Kasischke and Bourgeau-Chavez 1997). Depending on the beam mode, Radarsat-1 can achieve spatial resolutions 
Table 2.1 - Spectral and spatial characteristics of common optical satellite sensors.

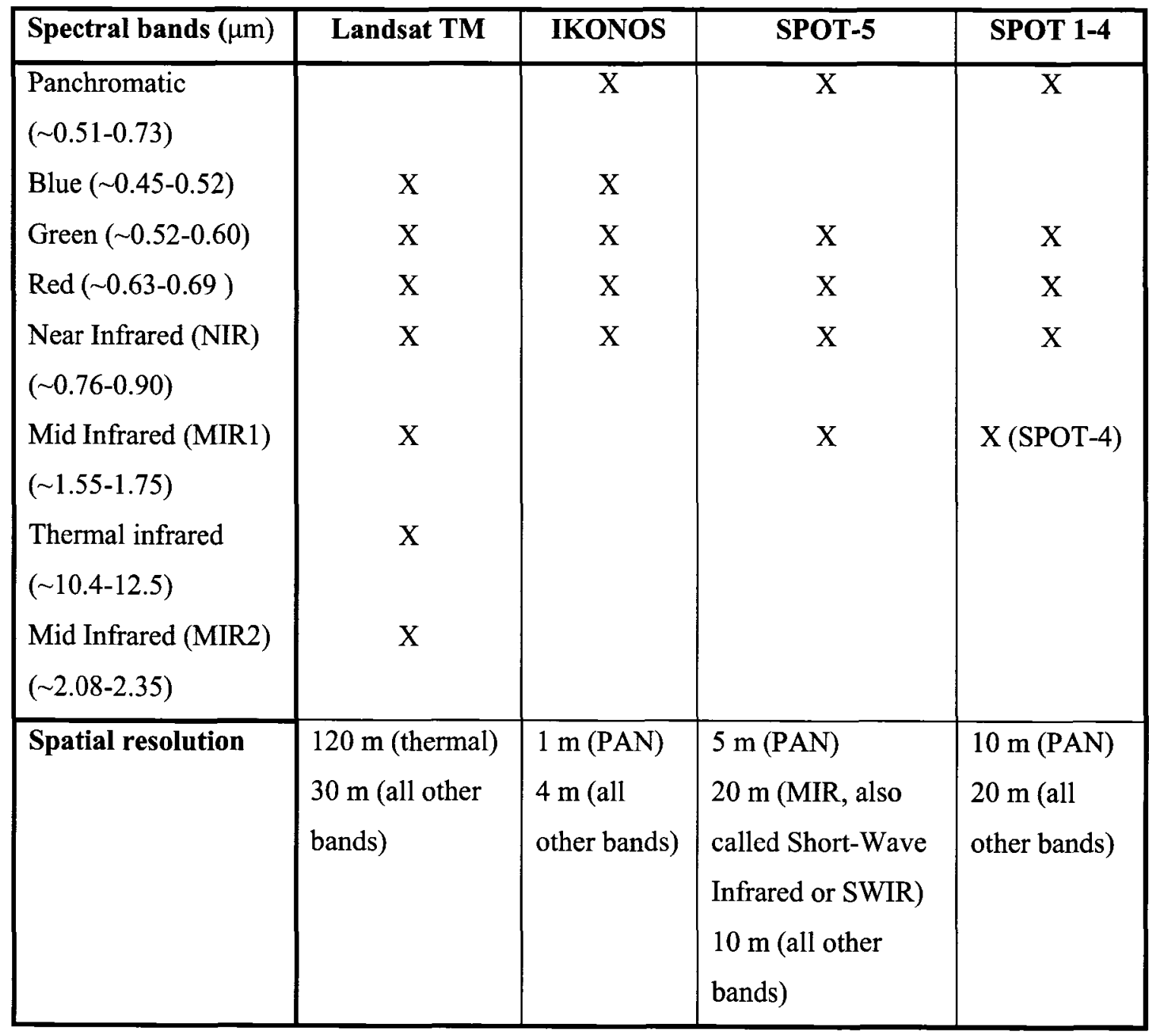


varying from $8 \mathrm{~m}$ to $100 \mathrm{~m}$. With higher spatial resolution satellite radar such as Radarsat-2, which will be launched in late 2007, or airborne radar, pixel size can be $3 \mathrm{~m}$ or less.

A key concern with regards to selecting a sensor type is the spatial resolution analogous to the scale of observation (Woodcock and Strahler 1987). Spatial resolution impacts the degree of aggregation of reflected radiance occurring in each pixel leading to mixed pixels where more than one type of land cover is present in the pixel (Davidson and Csillag 2001). The selection of an appropriate spatial scale is dependent on the information needs. In a study of Arctic tundra, Stow et al. (1993) found that about $30 \%$ of mapped vegetation units were less than the $20 \mathrm{~m}$ nominal spatial resolution of SPOT-2 multispectral (MS) data. For example, water track vegetation was the most difficult community type to resolve spatially because of its narrow width. This implies that Landsat cannot resolve some of the important components of tundra landscapes. Johansen and Phinn (2006) compared IKONOS and Landsat data in mapping species composition of riparian vegetation in Australian savannahs. They concluded that Landsat data could only be useful in delineating riparian zone widths greater than $50 \mathrm{~m}$ while IKONOS data were more successful in identifying narrow vegetation zones of $20-50 \mathrm{~m}$ in width but within a smaller image extent.

Spectral resolution is also an important consideration since it affects spectral separability of land cover classes. It would be difficult to distinguish vegetation units if there were no significant differences in spectral signatures. Johansen and Phinn (2006) attributed the successful identification of Melaleuca stands fringing stream bank sites to the inclusion of MIR bands despite the low spatial resolution of Landsat data. 
Good temporal resolution is necessary to be able to select the best data for discrimination of land cover types. However, most satellite sensors with high spatial do not have high temporal resolution (e.g. daily such as for the coarse spatial resolution AVHRR), thus limiting the number of possible acquisitions to a few during a time period of interest. IKONOS and SPOT-5 have a revisit rate of between 2-3 days, allowing for an adequate number of acquisitions for a particular point on the Earth.

\subsubsection{Image data transformations}

In addition to spectral data produced directly by different sensors, data transformations such as vegetation indices (VI), texture analysis and Principal Component Analysis (PCA) can be used to generate additional image information for classification. This section summarizes those that are relevant to this research.

\subsubsection{Vegetation Indices (VI)}

It has been established in a range of ecosystems that transformations of band reflectances can be correlated with plant biophysical characteristics and are generally less sensitive to external variables such as sun angle (Laidler and Treitz 2003). The most widely used of these transformations is the Normalized Difference Vegetation Index $(\mathrm{NDVI}=(\mathrm{NIR}-\mathrm{Red}) /(\mathrm{NIR}+\mathrm{Red}))$. NDVI is useful mainly because it is computationally simple and normalizes the difference between maximum vegetation absorption within the red wavelengths and peak reflectance in the NIR. The relation between the Red and NIR bands provides the most information regarding vegetative properties such as green biomass and chlorophyll content (Lillesand et al. 2004). 
NDVI has been found to be sensitive to variations in soil reflectance in canopies of less than $100 \%$ cover and, therefore, modified indices have been developed. Indices such as the Soil Adjusted Vegetation Index (SAVI) and the Modified Soil Adjusted Vegetation Index (MSAVI) were deemed to be useful to tundra vegetation communities (Laidler and Treitz 2003), and riparian vegetation mapping (Johansen and Phinn 2006).

SAVI is defined as:

$$
\mathrm{SAVI}=[(\mathrm{NIR}-\mathrm{Red}) /(\mathrm{NIR}+\mathrm{Red}+\mathrm{L})] *(1+\mathrm{L})
$$

where, $\mathrm{L}$ is a correction factor which ranges from 0 for very high vegetation cover to 1 for very low vegetation cover. An $L$ value of 0.5 has been found to best minimize the effects of soil-brightness induced variations (Johansen and Phinn 2006).

MSAVI was developed to demonstrate that $\mathrm{L}$ is not a constant but a function that varies inversely with the amount of vegetation present (Bannari et al. 1995):

$$
\operatorname{MSAVI}=\left[2 \mathrm{NIR}+1-\left((2 \mathrm{NIR}+1)^{2}-8(\mathrm{NIR}-\mathrm{Red})\right)^{0.5}\right] / 2
$$

Spectral vegetation indices have been particularly useful in the estimation of LAI at a regional scale. Xavier and Vettorazzi (2004) examined the relation between LAI and several VIs in a subtropical watershed and used the best relation to generate a LAI map of the study area. High correlation was also found between seasonal LAI and NDVI patterns in shrub tundra in Alaska (Riedel et al. 2005).

NDVI, SAVI, and MSAVI were tested in this research for their usefulness in discriminating different vegetation communities in the Mackenzie Delta. Soil-adjusted indices were included since they might be valuable in vegetation associations with lowcanopy cover allowing the spectral mixing from ground cover such as bare soil. 


\subsubsection{Texture analysis}

With fine spatial resolution data, shadows resulting from topography and vegetation stand structures and the wide spectral variation within land-cover classes may produce significant overlap in spectral data distributions. Use of texture information can reduce this problem (Lu and Weng 2007). Image texture is the spatial variation in tone around a given point and is a measure of the overall visual "smoothness" or "coarseness". Pixels in homogeneous areas have more similar brightness values, compared to more heterogeneous areas. The main approach used in texture analysis is statistical, based on the grey level co-occurrence matrix (GLCM) (Jensen 1996). The GLCM is a moving two dimensional matrix that tabulates the co-occurrence probability of pairs of grey-level pixels within a local window around a given pixel. When a GLCM is computed, window size, inter-pixel angle, inter-pixel distance, and quantization should be considered. Window size refers to the region of contiguous pixels within which the GLCM is generated. If the window size is too small, insufficient spatial information is extracted to characterize a specific land cover and the number of samples may be too small to generate a representative probability distribution function. However, if the window is too large, it can overlap two types of ground cover and thus introduce erroneous spatial information. Therefore, window size for texture analysis is related to image resolution and the spatial extent of land cover entities within the image (Puissant et al. 2005).

Within the texture window, inter-pixel angle and inter-pixel distance, respectively, describe the direction and distance between pixel pairs. Unless there is a specifically oriented structure in a given land cover, sample angles in the horizontal, vertical and diagonals are used and the sample distance is usually one pixel. Quantization 
is the range of possible grey-level values to be considered. For 8-bit data, each GLCM is comprised of 256 rows and columns. Calculation of GLCMs for every pixel in an image may be computationally long so some algorithms re-sample data to lower quantization levels such as 6-bit (64 grey levels). From the GLCM, many texture measures can be derived. Measures such as Homogeneity (HOM), Contrast (CON), Dissimilarity (DIS), Entropy (ENT), Angular Second Moment (A2M), and Correlation (COR) have been used successfully along with spectral information in the mapping of wetlands and riparian vegetation (Bernier et al. 2003; Dillabaugh and King 2005) as well as of bird habitat in a forest environment (Pasher et al. 2007). HOM evaluates the degree of local homogeneity, while CON and DIS are measures of local variation. ENT analyzes the organization within the texture window in terms of the presence or absence of patterns. A2M is the opposite of ENT and indicates the uniformity of grey level values. Finally, COR assesses the spatial autocorrelation of neighbouring pixels (Jensen 1996).

\subsubsection{Principal Component Analysis (PCA)}

Interband correlation is a problem often encountered in the analysis of MS data. PCA removes this redundancy of information by linearly transforming the data through rotation and translation to a set of components that are orthogonal and uncorrelated (Lillesand et al. 2004). The first principal component (PC1) contains the largest percentage of the total image variance and succeeding components each contain a decreasing percentage of the scene variance. Individual PCs can represent specific gradients such as amounts of vegetation or moisture. Generally, the total data variance is represented by fewer numbers of components than the original variables and data 
dimensionality and noise can be reduced. In addition, for statistical classifiers, PCA provides a set of variables that satisfy data independence requirements.

\subsubsection{Image classification}

\subsubsection{Classification stages}

A variety of unsupervised and supervised classification algorithms have been used in remote sensing. Usually, a combination of the two approaches is employed to enhance accuracy. In the unsupervised approach, the image data are first automatically classified by aggregating them into clusters. The analyst then determines the land cover identity of these clusters by comparing them to ground reference data. In supervised classification, the process can be broken into three stages: (1) the training stage, in which class descriptors are generated and training data are assessed for representativeness and separability (i.e. a statistical measure of how each class is distinct from one another); (2) the class allocation stage where each pixel is allocated to the class with which it has the greatest similarity; and (3) the validation stage, in which the accuracy of the classification is assessed (Lillesand et al. 2004). This testing stage is applicable to both unsupervised and supervised classifications.

\subsubsection{Parametric supervised classifications}

The classification techniques commonly used, such as the parametric Maximum Likelihood Classification (MLC), allocate each pixel to a single class. The per-pixel MLC, assuming that training data are normally distributed, determines the probability distribution of the training data for each class and allocates each unknown pixel to the 
class in which it has the highest probability of belonging. MLC generally gives better results than other parametric classifiers and is the most commonly used supervised classifier for mapping riparian vegetation (Ozesmi and Bauer 2002).

\subsubsection{Non-parametric supervised classifications}

Non-parametric classifiers, such as artificial neural networks (ANN) are also frequently used since they do not assume that the data are normally distributed. A common type of ANN is the feed-forward back-propagation network. An ANN has three types of layers: an input layer, one or more hidden layers, and an output layer, where each layer is composed of a number of nodes (Fig 2.5). The input nodes contain the input variable combination used for classification as well as the training data, and distribute the values they receive forward to nodes of the hidden layer. An ANN needs to be trained to learn the input patterns of interest. At each hidden layer node, the data are summed in a sigmoid function using assigned weights that are initially arbitrary defined for each input. The result at a given node is passed to all nodes in a subsequent layer. The nodes within the output layer correspond to desired output classes. The back propagation phase occurs when the error measured at the output nodes is fed backward through the network to modify the weights of the connections in the previous layer in proportion to the error. This proportion to the error is termed the learning rate. The training process repeats iteratively until the specified number of iterations or allowed maximum total and individual error levels have been met (Tso and Mather 2001).

The learning and momentum rates affect how quickly the neural network stabilizes. A low learning rate $(0.1)$ would take more iterations to train. In contrast, with a 


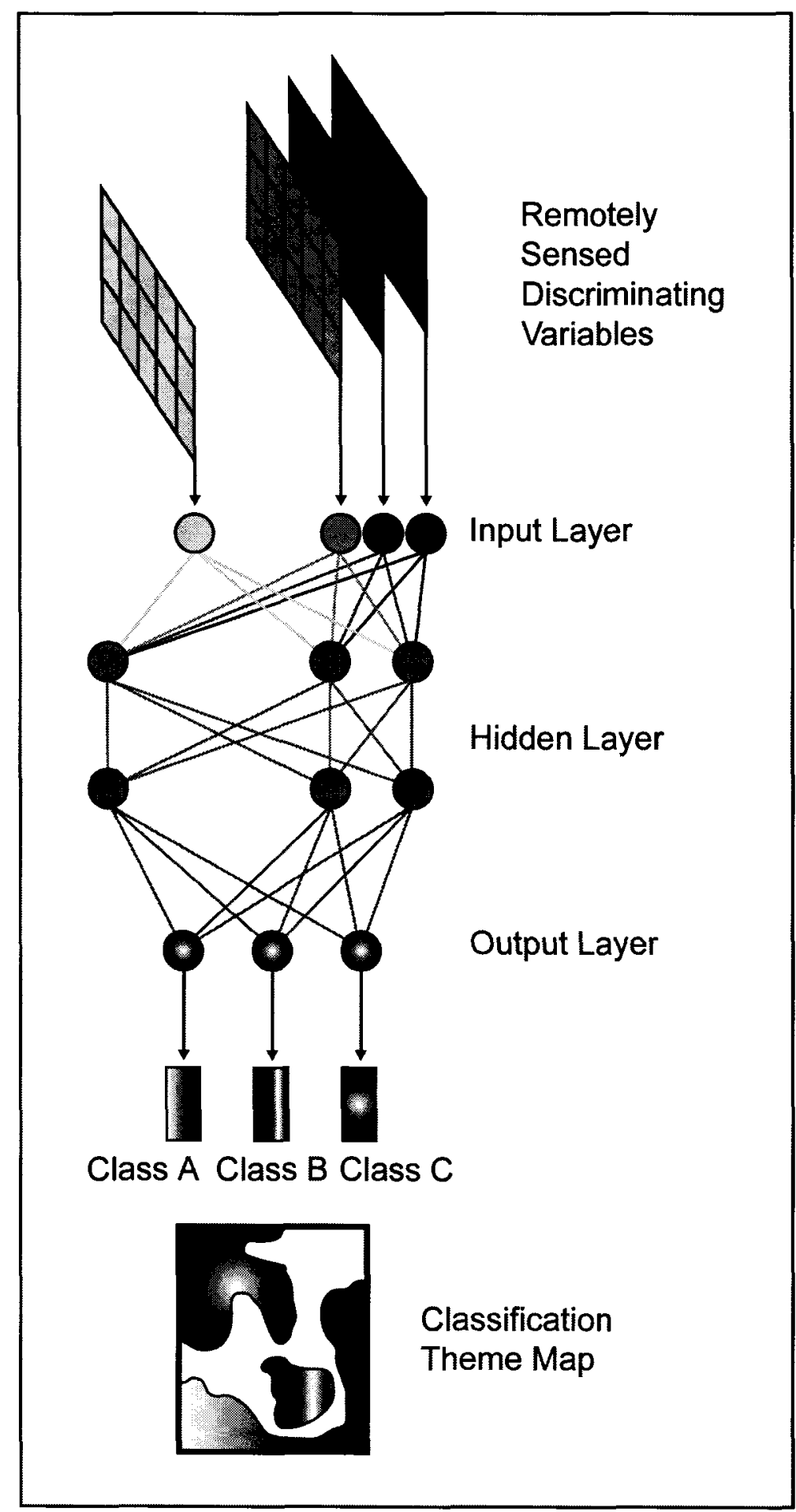

Fig. 2.5 - Artificial neural network applied to classification of remote sensing data. 
high learning rate (0.9), the modelling may oscillate and not stabilize. The momentum is a constant that can be added to the adjustment of weights in the back propagation phase and can be used to speed up learning. A high momentum (0.9) trains with larger steps than a lower rate (0.1) (PCI Geomatica 2005).

Many configurations of learning rate and momentum have been suggested in the literature. A learning rate of 0.1 and a momentum of 0.9 were used by Foody et al. (1996), while Bernier et al. (2003) used a momentum of 0.4 in order to classify wetlands in southern Québec. Kavzoglu and Mather (2003), in a study of the optimum design of ANNs for classification, found that a learning rate of 0.1 or 0.2 with a momentum of 0.5 or 0.6 resulted in higher classification results. Several studies found that ANNs produced classifications with higher accuracy levels compared to MLC. For example, Berberoglu et al. (2004) compared MLC and ANN for the mapping of coastal wetlands of Turkey using a Landsat TM image. The ANN classification produced the best overall accuracy and was found to be better capable of delineating classes of high heterogeneity and spectral complexity. However, in a regional-scale upland vegetation mapping study, Mills et al. (2006) found that the spectral variability of high-resolution IKONOS pixels over regional scales was too dynamic for ANNs resulting in lower accuracy levels.

\subsubsection{Soft classifications}

Per-pixel or "hard" classifiers may only be appropriate for the mapping of classes that are discrete and spatially mutually exclusive (Tso and Mather 2001). However, mixed pixels often occur in transition zones where classes co-exist spatially, such as zones where one type of vegetation intergrades into another. "Soft" classifications, such 
as linear spectral unmixing and fuzzy classifiers, have been proposed as alternatives to traditional classifiers (Bastin 1997). The output from soft classifiers provides a set of fraction images that are related to the proportion of classes in each pixel. However, the use of soft classifiers is still limited by the intensity with which accuracy assessment must be conducted (Stehman et al. 2007).

In the linear spectral unmixing process, the reflectance values associated with a mixed pixel are assumed to be linear combinations of the reflectance of the constituent ground cover types. Unmixing can be used to decompose the mixed spectra in order to determine sub-pixel proportions of each cover types (Tso and Mather 2001). Training data are assumed to represent the reflectance of a pixel that contains only one particular land cover class. These endmembers, from which all mixtures present in an image are formed, must be composed of pure pixels of each land cover class in an image.

Endmembers are typically acquired by selecting pure pixels from within the image by manually delineating pure areas of each endmember, selecting pure areas from n-dimensional spectral space through scatterplots, or using automatic endmember selection functions such as ENDMEMB in PCI Geomatica. Manually selecting endmembers was deemed to be the easiest technique while giving similar performance to the other methods (Pasher et al. 2007). Pasher et al. (2007) manually extracted vegetation, soil, and shadow endmembers from IKONOS images in order to investigate canopy gap characteristics. Bannari et al. (2006) also successfully used a manual endmember extraction approach to map crop residue cover on agricultural lands using hyperspectral and IKONOS data. 


\subsubsection{Accuracy assessment of classified maps}

Meaningful and consistent measures of map accuracy are necessary for users to evaluate the suitability of the map data for their specific application. Map accuracy measures also allow analysis of sources of error and comparison of classification strategies (Foody 2002). Various accuracy measures have been developed and there is no agreement on a standard approach to thematic map accuracy assessment. However, in comparative assessments of the measures of thematic classification accuracy, Congalton (1991) and Liu et al. (2007) recommended that user's accuracy, producer's accuracy and the overall accuracy should be provided as primary accuracy measures.

These three measures are derived from an error matrix, which expresses the number of sampling units assigned to a particular category relative to the actual category as verified on the ground (Lillesand et al. 2004). Producer's accuracy indicates the probability of a reference pixel being correctly classified and is an inverse measure of omission error. User's accuracy indicates the probability that a classified pixel actually represents that category on the ground and is an inverse measure of commission error. Overall accuracy is calculated by dividing the total number of correctly classified pixels by the total number of pixels in the matrix (Congalton 1991).

Although an $85 \%$ accuracy level, usually used for local-scale accuracy assessments, is widely accepted by the remote sensing community as a benchmark, its usefulness for regional-scale mapping projects is unclear (Wulder et al. 2006). The accuracy evaluations of several recently completed regional-scale land cover mapping projects indicated that producer's and user's accuracies were stabilizing in the $50-70 \%$ range, independent of level of taxonomic detail or methodological approaches (e.g. 
Edwards et al. 1998, Ma et al. 2001). The minimum map accuracy method has been found suitable for large-area land cover product validation. According to this method, the minimum acceptable map accuracy for a significance level of $95 \%$, a sample size of 100 and assuming a target accuracy of $80 \%$ is $73.4 \%$ (Wulder et al. 2006).

\subsubsection{Remote sensing of permafrost conditions}

By correlating above-surface characteristics with ground conditions, remote sensing may be used to infer the occurrence of permafrost (Duguay et al. 2005). Persistent problems with permafrost field data are their irregular distribution in space and time, and the variety of observation techniques used in their collection, which makes compiling maps of broad areas difficult. Therefore, Heginbottom (2002), in a review of permafrost mapping methods, emphasized the need for techniques to permit reliable, automated mapping from remote sensed data. Morrissey et al. (1986) and Peddle and Franklin (1993) prepared maps of near-surface permafrost conditions for study areas of about $100 \mathrm{~km}^{2}$ in Alaska and the Yukon Territory by using various combinations of topography, vegetation cover, and classifiers. Their classifications of permafrost zones achieved good accuracy levels but were very general: $>95 \%, 5-95 \%$, and $<5 \%$ of the area underlain by permafrost.

Leverington and Duguay (1997) successfully used a neural network approach to determine the likelihood of permafrost occurrence for each pixel in a Landsat TM image for a 18 x $18 \mathrm{~km}$ study area near Mayo, Yukon Territory. However, training data, the spatial extension of which is vital in region-wide mapping, could not be transferred to another adjacent study area. Differences in subsurface properties were the overriding 
factor in the prediction of permafrost presence as emphasized in a separate study by Williams and Burn (1996) in the same region.

\subsection{Concluding remarks}

Surface and subsurface conditions intervene to buffer the thermal effects of the atmosphere on the ground. Such conditions can change significantly over short distances, and as a result, it is the microclimate which is of critical importance to local ground thermal conditions and their spatial variations. Since the extent of near-surface permafrost has not been determined quantitatively in the Mackenzie Delta, an examination of the environmental factors in the Delta is important in order to study how the variables controlling the distribution of permafrost are configured in that setting.

Few studies have used remote sensing to study terrain types or to map permafrost in the Mackenzie Delta. Boyes (1991) used Landsat TM data to identify vegetation patterns in the Delta. However, no accuracy assessments were conducted. More recently, Hall-Atkinson and Smith (2001) applied SAR interferometric images in order to delineate ecozones in the Delta. Their classifications of vegetative land cover were, however, inappropriate for permafrost mapping since they did not differentiate between riparian zones known to be associated with presence/absence of near-surface permafrost. The goal of this research is to map vegetation communities in the Delta linked to presence or absence of near-surface permafrost based on field-validated data and to estimate the proportion of the Delta underlain by permafrost. 


\section{CHAPTER THREE}

\section{FIELDWORK IN THE MACKENZIE DELTA}

\subsection{Introduction}

This chapter describes the environmental conditions in the Delta. Field methods and techniques used to determine the locations of sampling sites are also described. Nearsurface ground conditions were investigated and vegetation was sampled at sites representing the various vegetation communities throughout the Delta.

\subsection{Environmental conditions in the Mackenzie Delta}

\subsubsection{Location and geomorphic setting}

The Mackenzie Delta stretches 200 km from Point Separation near Tsiigehtchic, N.W.T., north to the Beaufort Sea, has an average width of about $60 \mathrm{~km}$, and a total area of nearly $13000 \mathrm{~km}^{2}$ (Fig. 1.1). The Delta is a Holocene feature and is distinct from surrounding regions as it is subjected to annual flooding. It is usually divided into three sections that correspond with two major reductions in levee height: the upper southern delta, the middle central delta, and the outer or lower northern delta (Mackay 1963). North of Tununuk, the Delta is bounded to the east by Richards Island, and East Channel forms the eastern boundary south of Tununuk. The Delta is bounded to the west by Richardson Mountains.

The maximum relief of the Delta is $10 \mathrm{~m}$ above sea level in the southern delta with a gentle slope to the Beaufort Sea (Bigras 1990). Striking features of this essentially flat delta are the network of shifting channels, the thousands of lakes of varying size, and the distinctive zones of vegetation adjacent to these water bodies (Fig. 3.1) (Pearce 1998). 


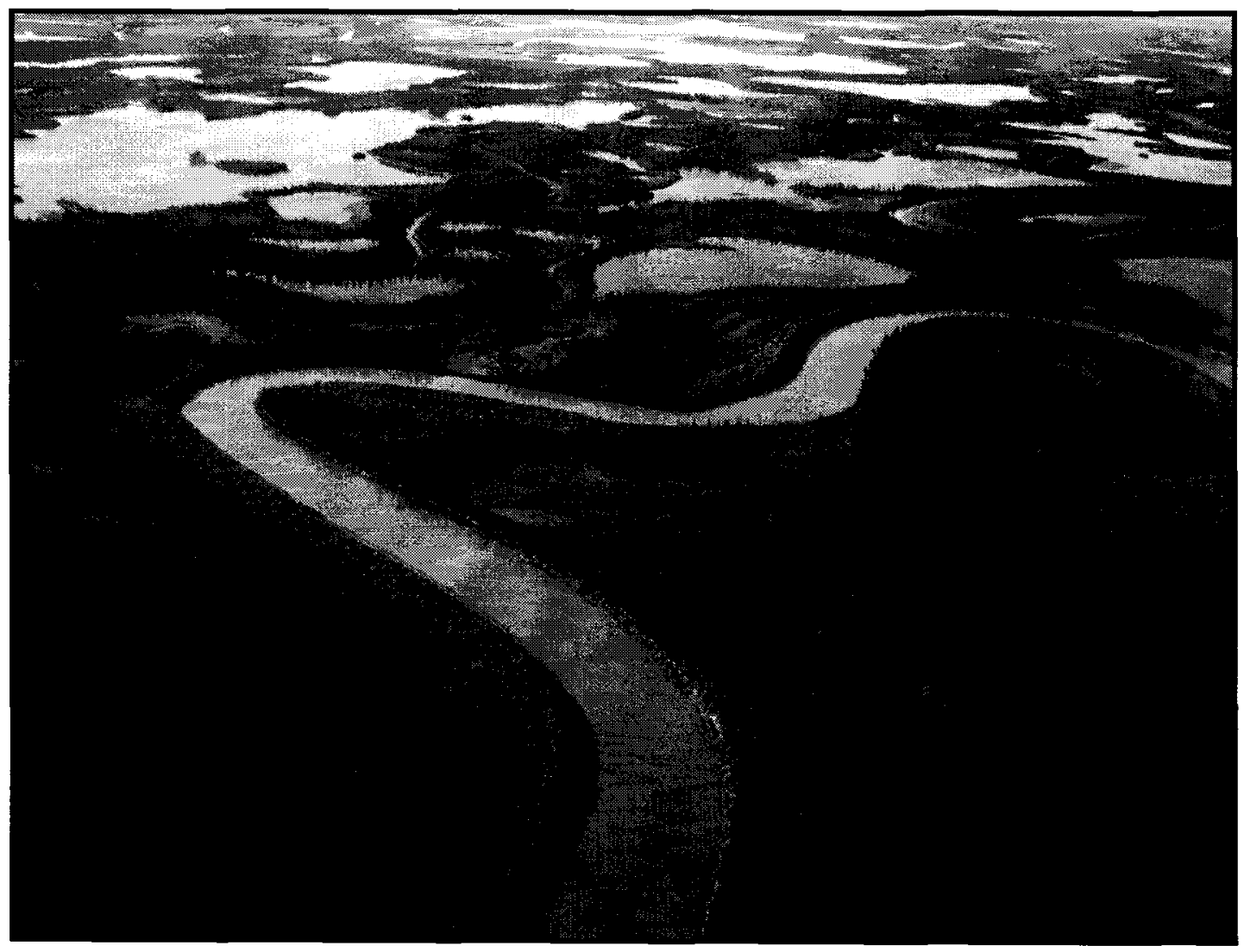

Fig. 3.1 - The Mackenzie Delta is characterized by a network of shifting channels and thousands of lakes of varying size. This photograph was taken over the southwestern delta on August 20, 2006. 


\subsubsection{Climate}

The northern third of the delta, north of tree line, is in the Low Arctic climatic zone while the southern two-thirds, south of tree line, are in the High Subarctic climatic zone. The average annual precipitation rate is $200 \mathrm{~mm}$ with $50 \%$ arriving as snow between October and April. While the average snow depth in March near Inuvik is 60 $\mathrm{cm}$, snow redistribution by wind is common, and snow banks more than $2 \mathrm{~m}$ thick can form (Burn 2002b). Average snow depth at Tuktoyaktuk, the closest meteorological station to the northern Delta, is about $35 \mathrm{~cm}$. This lower snow accumulation at the coast is associated with the dominance of dry arctic air and the greater distance from moisturecarrying storms which track further to the south (Dyke 2000b).

The mean annual air temperature in Inuvik is $-10^{\circ} \mathrm{C}$, with long and cold winters $\left(-30{ }^{0} \mathrm{C}\right.$ January mean temperature $)$, and cool $\left(14{ }^{\circ} \mathrm{C}\right.$ July mean temperature $)$ and short summers (Burn 2002b). The Beaufort Sea has a significant impact on spring and early summer temperatures. Persistent ice cover delays the onset of spring and shortens the length of the growing season at sites within $50 \mathrm{~km}$ of the coast (Burn 1997). For example, climate normals from 1971-2000 indicate that mean June air temperature in Inuvik is 11 ${ }^{\circ} \mathrm{C}$, which is significantly warmer than Tuktoyaktuk at $6{ }^{\circ} \mathrm{C}$ (Environment Canada 2007).

The Mackenzie Delta is an area of particularly rapid climate warming (Serreze et al. 2000). The difference in climate normals at Inuvik and Tuktoyaktuk between 19511980 and 1971-2000 indicate an increase in mean annual air temperature of about $1^{\circ} \mathrm{C}$ (Environment Canada 2007). There has been no consistent change in annual total precipitation during the same time period (Burn et al. 2004). Dendroecological studies in 
the Delta also indicate climate change, as the growth response of white spruce to summer temperature has altered in association with $20^{\text {th }}$ century warming (Pisaric et al. 2007).

\subsubsection{Hydrologic regime}

The Mackenzie River supplies about $90 \%$ of the total discharge into the Delta through a maze of channels ranging in depth from about $1 \mathrm{~m}$ to $50 \mathrm{~m}$ (Brooks 2000). During late winter, ice-cover thickness averages 1.5 to $2 \mathrm{~m}$ and most channels do not freeze to the bottom (Hollingshead et al. 1978). The peak in Mackenzie River discharge typically occurs in late May or early June with an increase in water levels of 3 to $6 \mathrm{~m}$ above winter ice levels over a period of one to two weeks (Bigras 1990; Burn 1995). Since levee heights in the Delta decrease towards the Beaufort Sea, a greater proportion of the Delta surface is inundated by spring flooding as distance from Point Separation increases (Marsh and Hey 1991). The main factors that affect flood frequency and duration at a particular location are the elevation of the ground in relation to each flood peak and the distance from the flooding channel (Mackay 1963).

Subsequent to spring flooding, water levels decline over a period of two to four weeks. During the summer, water levels may rise due to rainfall and storm surges in the Beaufort Sea (Marsh and Schmidt 1993). The Delta is ice-free for about four months until freeze-up in October. Most terrestrial surfaces undergo active sedimentation or erosion due to shifting channels (Mackay 1963; Gill 1972). The average rate of channel migration has been estimated to be up to a few metres/year (Smith and Hwang 1973; Dyke 2000a). Sedimentation rates vary with frequency and duration of flooding (Marsh and Hey 1991). Pearce (1998) measured sedimentation rates on diverse Delta surfaces and differentiated sedimentation, ranging from one to tens of $\mathrm{cm} /$ year, by vegetation community. 


\subsubsection{Vegetation communities}

There are three general vegetation zones in the Delta (Mackay 1963). The southern delta is occupied by boreal forest dominated by spruce (Picea). The central delta represents a transition zone from boreal to tundra vegetation. Here, the coverage of spruce is reduced and shrub species such as willows (Salix) and alders (Alnus) are widespread. The northern delta is covered with a number of low tundra shrubs and herbs dominated by willow and sedge (Carex) species. At a more local scale, a combination of factors, such as the amount and frequency of sedimentation and erosion, determine what plants will thrive on a particular landform. These factors, associated with the continuous production of new land surfaces through the shifting of channels, have led to the development of a plant succession on point bars (Fig. 3.2) (Gill 1972; Pearce 1998).

The Horsetail (Equisetum) communities are the typical emergent plant associations (Fig. 3.3a). They are located near shorelines and can tolerate a high flood frequency and duration and a high sedimentation rate. Willow-horsetail communities can be found with increasing distance from the stream channels and can tolerate a more moderate fluvial regime with the annual spring flood but with fewer floods in summer (Fig. 3.3b). Horsetails and willows have adapted to high sedimentation rates and prolonged annual flooding by producing adventitious roots and stems that can force their way through the overlying sediment deposits (Gill 1972; Pearce 1998).

Alder plant communities can be found at slightly higher elevations than the Willow-horsetail communities, since alder species are less tolerant of sedimentation (Fig. 3.3c). The decreased flood impact increases soil organic matter, and also allows the colonization of many herbs which could not survive large deposits of sediment every 


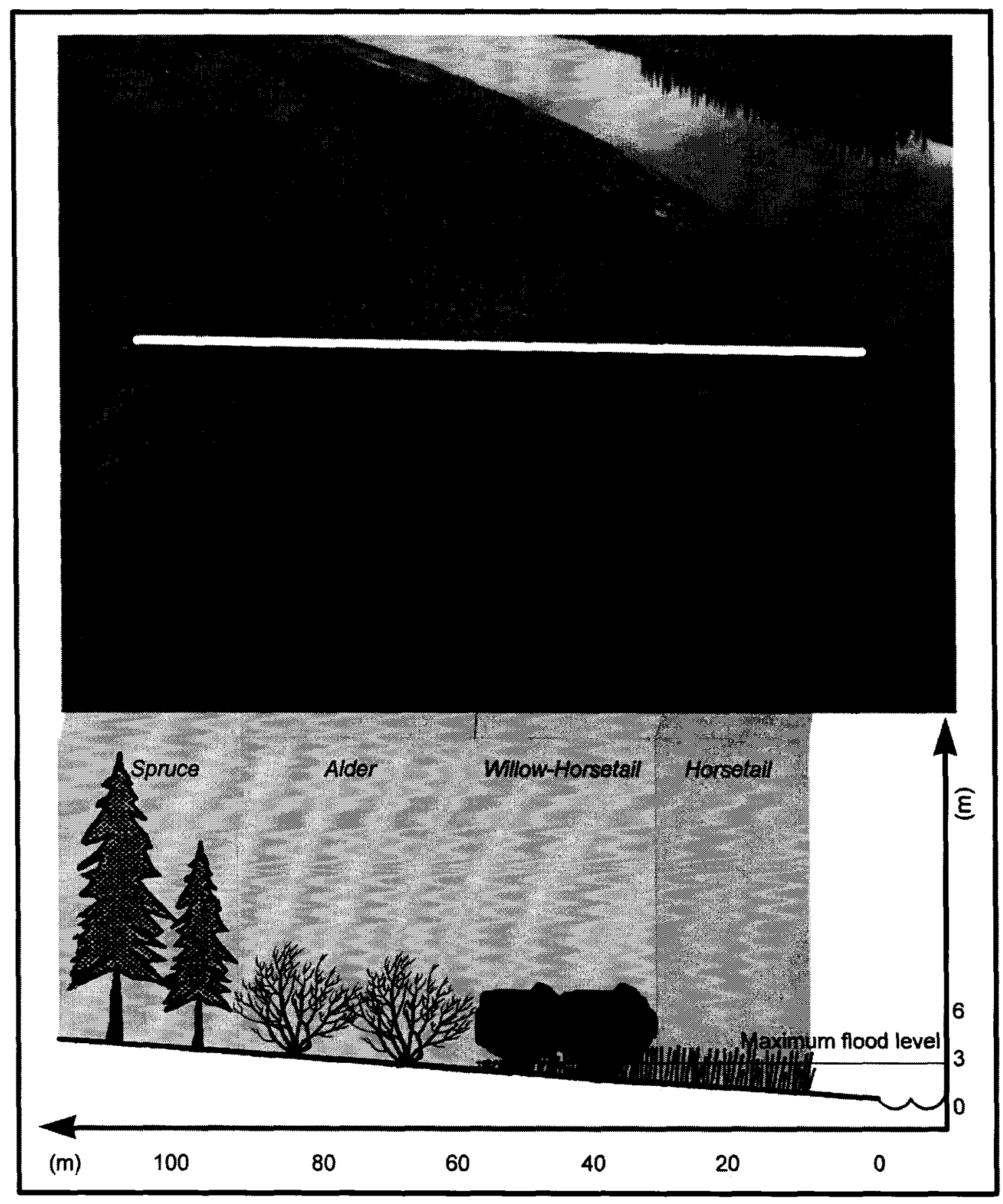

Fig. 3.2 - Plant succession showing flood tolerance groups on point bars in the southern and central delta. The maximum flood level line refers to the average annual spring flood height (based on Gill 1972; Boyes 1991; Pearce 1998). The photograph was taken on August 20, 2006, at site SD13 in the southern delta. 

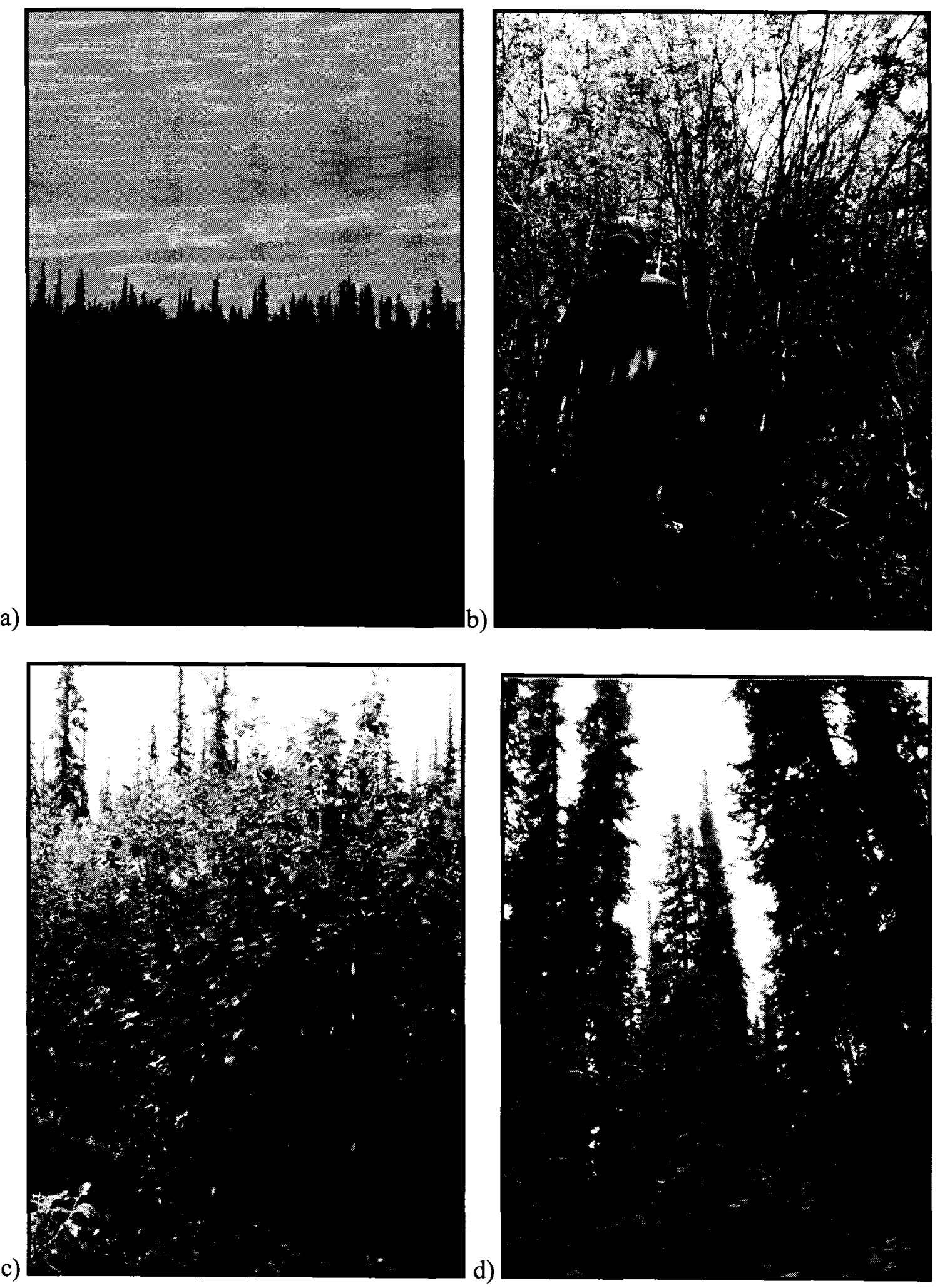

Fig. 3.3 - Typical vegetation communities in the Delta: a) horsetail; b) willow-horsetail;

c) alder; and d) spruce. Spruce forests are absent in the northern delta. 
year. Spruce communities represent the climax community in the central and southern delta and experience low flood frequency, flood duration and sedimentation (Fig. 3.3d). North of tree line, most land surfaces are flooded annually due to their low elevation, and vegetation is adapted to these conditions. Sedges and horsetails are common adjacent to channels, and willows are widespread on more elevated sites (Gill 1972; Pearce 1998).

\subsubsection{Permafrost}

The thermal effect of water bodies in the Delta and the shifting nature of channels affect the age, distribution and thickness of permafrost (Smith 1976). On aggrading point bars, the thickness of permafrost increases with distance from the shifting stream channel but remains less than $100 \mathrm{~m}$ thick because of the warming effect of numerous water bodies (Dyke 2000a). Based on climate, permafrost should be continuous in the Delta (Fig. 2.1). However, the most recent permafrost map in the Atlas of Canada, classifies the Delta as having discontinuous permafrost (Fig. 3.4). The extent of permafrost in the Delta was estimated as between $35-65 \%$ due to warming of the ground by advected heat from the Mackenzie River and the large proportion of the Delta occupied by lakes with subjacent taliks (Heginbottom 2000). The determination of near-surface permafrost extent is important for land-use regulation, as terrain behaviour varies between frozen and unfrozen ground. The recent permafrost map presents information in relation to physiographic units, rather than in terms of zonal climate as for earlier maps, and it made use of sparse ground temperature data (Heginbottom 2000). There has been little fieldwork investigating permafrost extent quantitatively and covering representative regions of the Delta. 


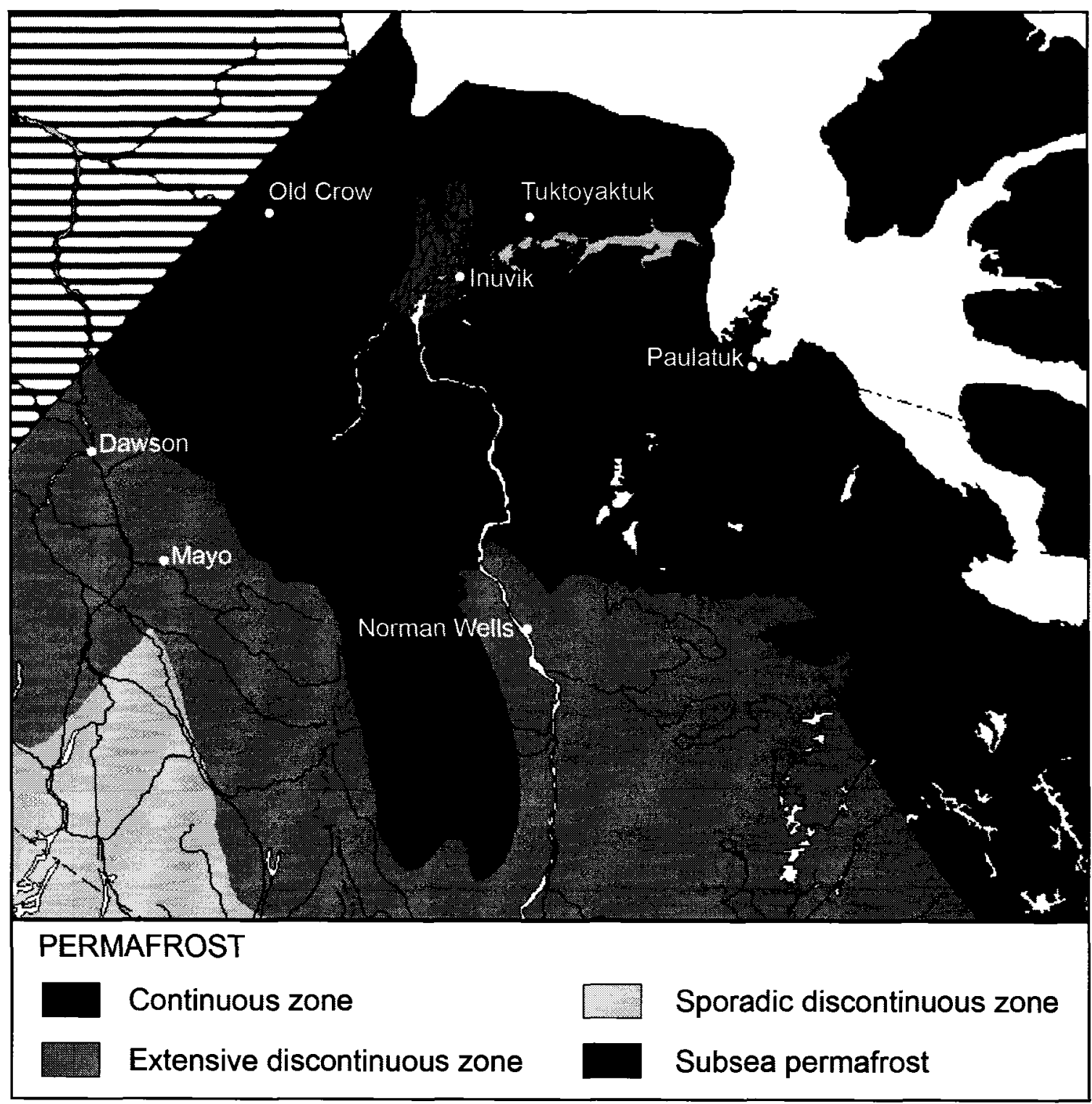

Fig. 3.4 - The Mackenzie Delta is classified as having discontinuous permafrost in the most recent edition of the Atlas of Canada (after Heginbottom et al. 1995). 
Taliks beneath the ground, and near shifting channels, have been recognized by various authors (Fig. 3.5) (Gill 1973; Smith 1975). The talik beneath a shifting channel follows the channel migration. When the surface previously occupied by a channel is exposed, it gradually cools and permafrost forms there anew. The thermal recovery rate depends on the distance from the channel. The further from the channel, the older the land surface, therefore the degree of thermal recovery is also more advanced and permafrost is thicker. Also, heat dissipation from saturated sediments near shorelines is further delayed by a contribution of latent heat during phase change as freezing occurs.

Therefore, the absence of near-surface permafrost or the presence of a talik where winter freeze-back does not reach the top of permafrost, is due to the slow thermal recovery of these new land surfaces on point bars combined with the insulating effects of deep snow blown by the wind off the channels and trapped in near-shore shrub stands (Gill 1973). In a study of microclimatic influences on ground temperatures and permafrost distribution at a site just north of Inuvik, summer ground temperatures were found to follow the trend of air temperatures closely (Smith 1975). However, in winter, the correlation was much weaker implying that snow cover must be primarily responsible for differences in ground temperatures between vegetation associations. Smith (1975) measured $41 \mathrm{~cm}$ of March snow accumulation in the Horsetail community, $116 \mathrm{~cm}$ in the Willow-horsetail zone, $80 \mathrm{~cm}$ in the Alder zone, and $59 \mathrm{~cm}$ in the spruce forest. Although along the channelward margin of the Willow-horsetail zone snowdrifts were compacted, their higher depth was sufficient to form an effective insulating cover. Zones of absence of near-surface permafrost in the Delta are areas of transient conditions where the ground thermal regime is not yet in equilibrium with climate. At locations other than point bars 


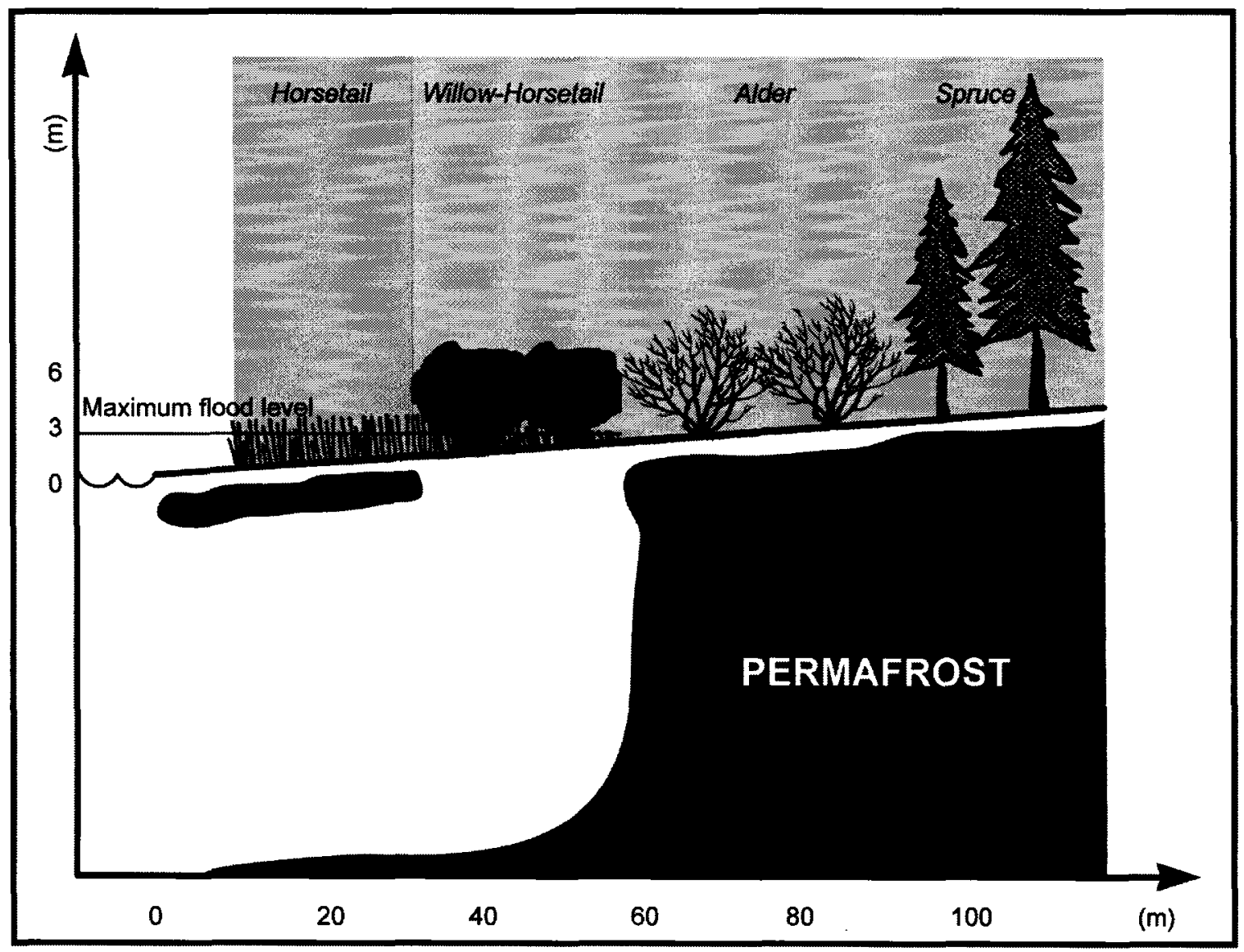

Fig. 3.5 - The presence of a talik near shorelines on point bars is due to the slow thermal recovery of these new land surfaces combined with insulating effects of deep snow blown by the wind off the channels and trapped in willow stands. Thin permafrost lenses underly the horsetail zones due to low mean annual surface temperatures. Snow is blown off the bare ground near shorelines allowing a higher amount of heat dissipation from the ground. 
and alluvial islands, taliks have not been reported in the literature. Near-surface permafrost is present in more stable geomorphic positions such as along lakeshores where there could also be a great accumulation of snow due to willow stands (Gill 1973). The spatial correlation between vegetation associations and presence of near-surface permafrost was established for a few sites in the central delta by Gill (1973) and Smith (1975). It is important to determine if this relation can be extrapolated to the whole delta.

\subsubsection{Subsurface conditions}

Subsurface conditions, consisting of silt and clay-size sediment, are comparable throughout the Delta. A deep bore hole drilled near Inuvik penetrated $54 \mathrm{~m}$ of alluvial sands and silts, $8 \mathrm{~m}$ of dense clay and $7 \mathrm{~m}$ of pebble clay before hitting bedrock (Johnston and Brown 1965). Fine-grained sediments and a rising permafrost table encountered in an alluvial environment are favourable to the growth of near-surface aggradational ice, which was confined to the top $10 \mathrm{~m}$ (Johnston and Brown 1965; Kokelj and Burn 2005b).

\subsection{Study site selection}

\subsubsection{Delta regions}

Based on elevation and related flooding and sediment regime, as well as vegetation, the Mackenzie Delta can be divided into five regions (Fig. 1.1). The different sediment sources separate the Delta into eastern and western sections, which are further subdivided from south to north based on levee height and tree line (Mackay 1963).

Since the first research objective is to assess if the spatial distribution of vegetation associations can be used to predict near-surface permafrost presence in the 
Delta, and also to reduce travel time, field sites were selected so that several representative vegetation classes were present at each site. Given the often muddy and bushy terrain, the line transect methodology was adopted for vegetation sampling and permafrost probing because it allows the investigation in the most timely fashion.

\subsubsection{Site selection}

Since no high-resolution satellite images were available for the Mackenzie Delta prior to summer 2006 fieldwork, non-georeferenced aerial photographs from the Mackenzie Valley Air Photo Project 2004 and a Landsat 7 ETM+ satellite image from 1999 were used to select field sites. The colour air photos used were at 1:30 000 scale, and originated from a federal initiative led by Indian and Northern Affairs Canada. The orthorectified Landsat 7 ETM+ image used was available from Geobase and has a horizontal positional accuracy of $50 \mathrm{~m}$ (Geobase 2007).

Unsupervised Isodata classification with PCI Geomatica's default value of 16 clusters was used with the Landsat image in order to spectrally stratify the study area. Isodata was chosen over other algorithms as it may be superior in initiating spectral clusters and it was used in previous riparian vegetation studies (Johansen and Phinn 2006). No labelling of terrain types based on the spectral classes was attempted at this stage. Selection of transect locations ensured that they covered unique spectral classes in the five delta regions and were accessible by boat (Fig. 3.6). Since the field sites were not selected randomly, a minimum distance of $1 \mathrm{~km}$ was maintained between transects, in order to reduce the potential for spatial autocorrelation. However, no semi-variogram was calculated to determine the characteristic spatial scales of different vegetation classes. 

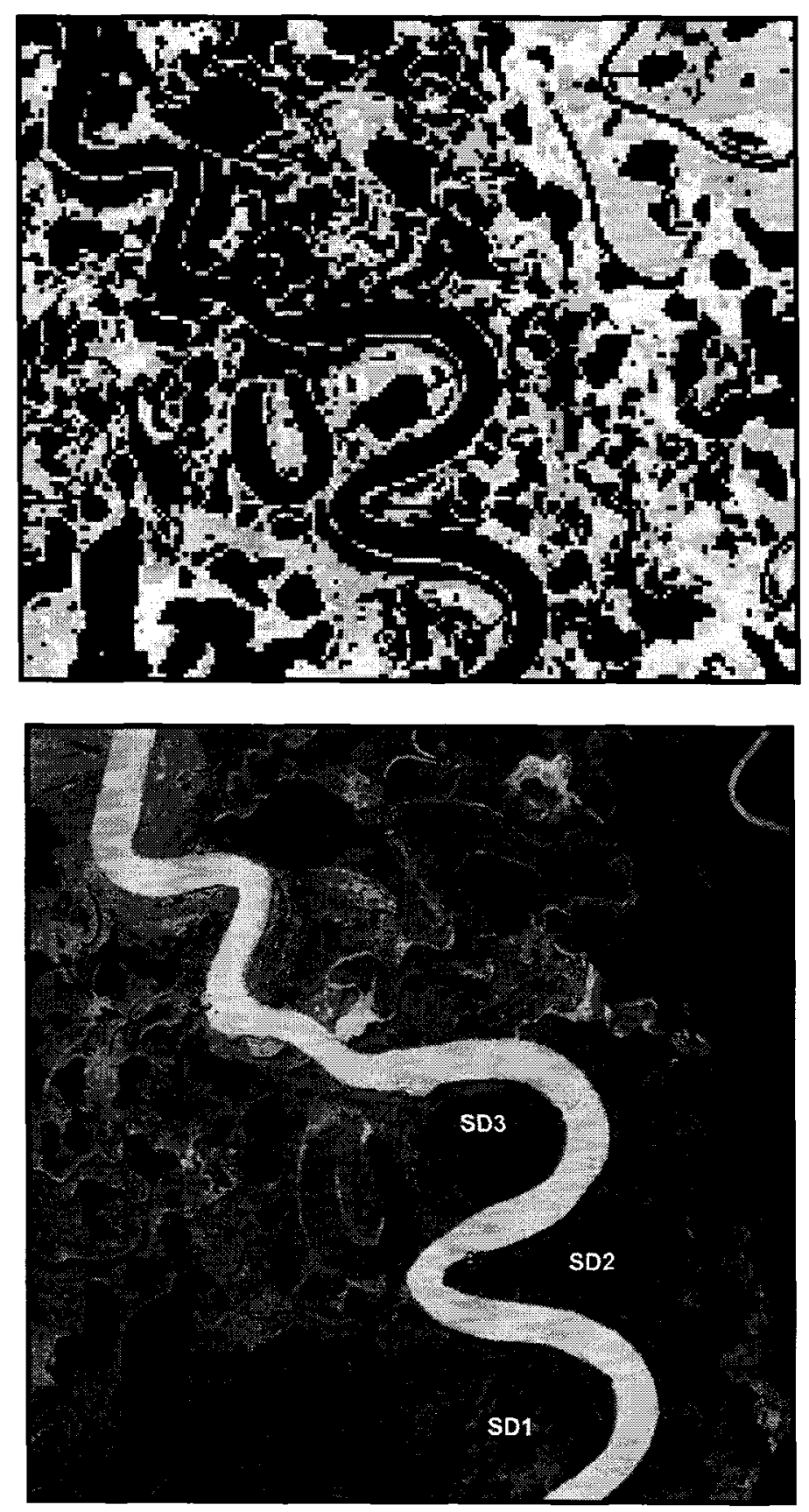

Fig. 3.6 - Field transects were located with a Landsat image at easily accessible sites with spectral variations. These transects were then identified on aerial photographs, which were used as field guides. This figure shows sites SD1, SD2, and SD3 on Peel Channel. Aerial photograph A31870-206 taken on August 15, 2004, is from Indian and Northern Affairs Canada. 
This identification of field sites also determined the coverage extent of the SPOT5 images that were ordered for July 2006. Although the spatial resolution of SPOT-5 is coarser than IKONOS, it has a SWIR band that was expected to help in discriminating vegetation communities. For regional scale mapping, SPOT-5 also has the advantage of a larger image coverage of $60 \mathrm{~km} \times 60 \mathrm{~km}$ compared to $11 \mathrm{~km} \times 11 \mathrm{~km}$ for IKONOS.

\subsection{Field methods}

\subsubsection{Sampling window}

A total of 52 transects were laid on point bars and alluvial islands from June to late August 2006 (Figs. 3.7-3.9). The majority of transects were between 100-200 m long depending on the width of different vegetation zones found. The number of transects was divided roughly equally between the five delta sub-regions and were established perpendicular to the shoreline and crossing the successional sequence of vegetation (Fig. 3.10). Ideally, all transects should have been investigated in July to fall as closely as possible to peak vegetative development, and to ensure similarity of phenologic stage as well as to correspond to the satellite image acquisition window. However, the time to complete sampling protocols was a limiting factor in the amount and quality of data acquired and fieldwork had to be extended through the whole summer season.

\subsubsection{Vegetation sampling}

Vegetation associations were stratified into three layers: herbs, shrubs, and trees. By doing so, the composition of each layer was measured taking the plant community structure into consideration (Mueller-Dombois and Ellenberg 1974). The height limits of 


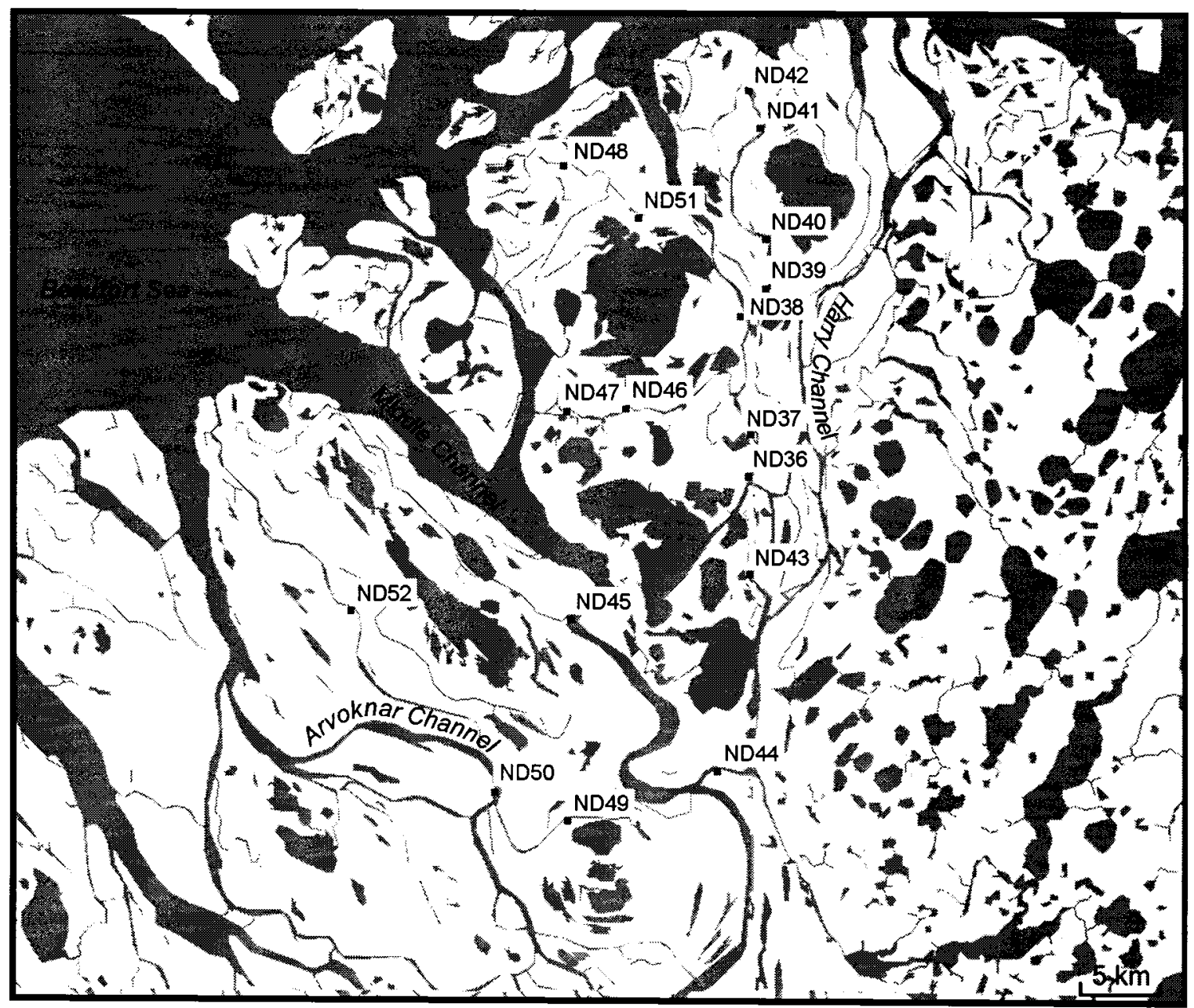

Fig. 3.7 - Transect locations in the northern delta. 


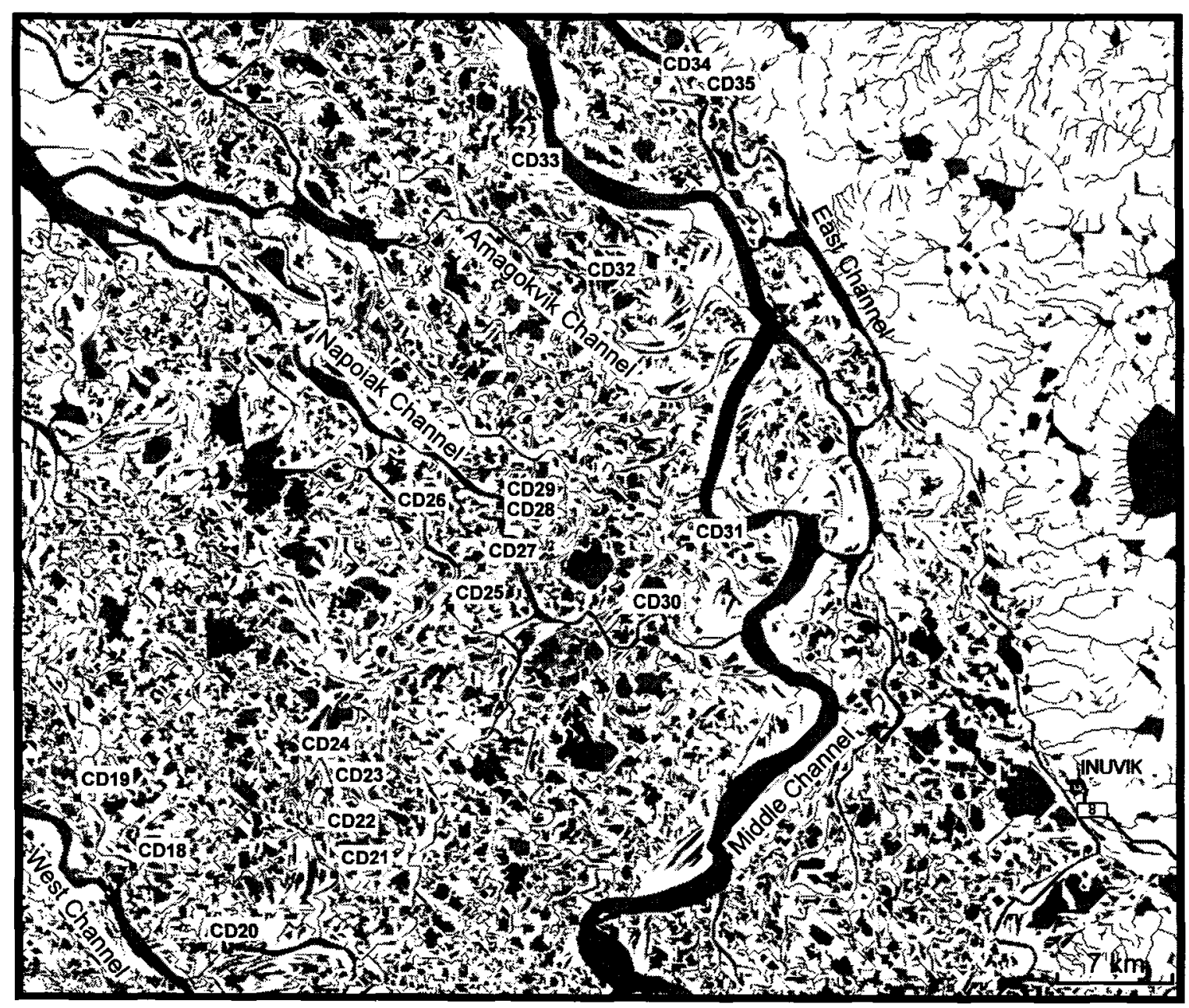

Fig. 3.8 - Transect locations in the central delta. CD18 to CD24 were set in the vicinity of Aklavik and Taylor Channels while CD25 to CD31 were located around Napoiak Channel. CD32 and CD33 were set in the neighbourhood of Amagokvik Channel and Axel Creek. CD34 and CD35 were sites in the area called Gill's Camp, this region was the focus of research by Gill (1973) and Smith (1975). 


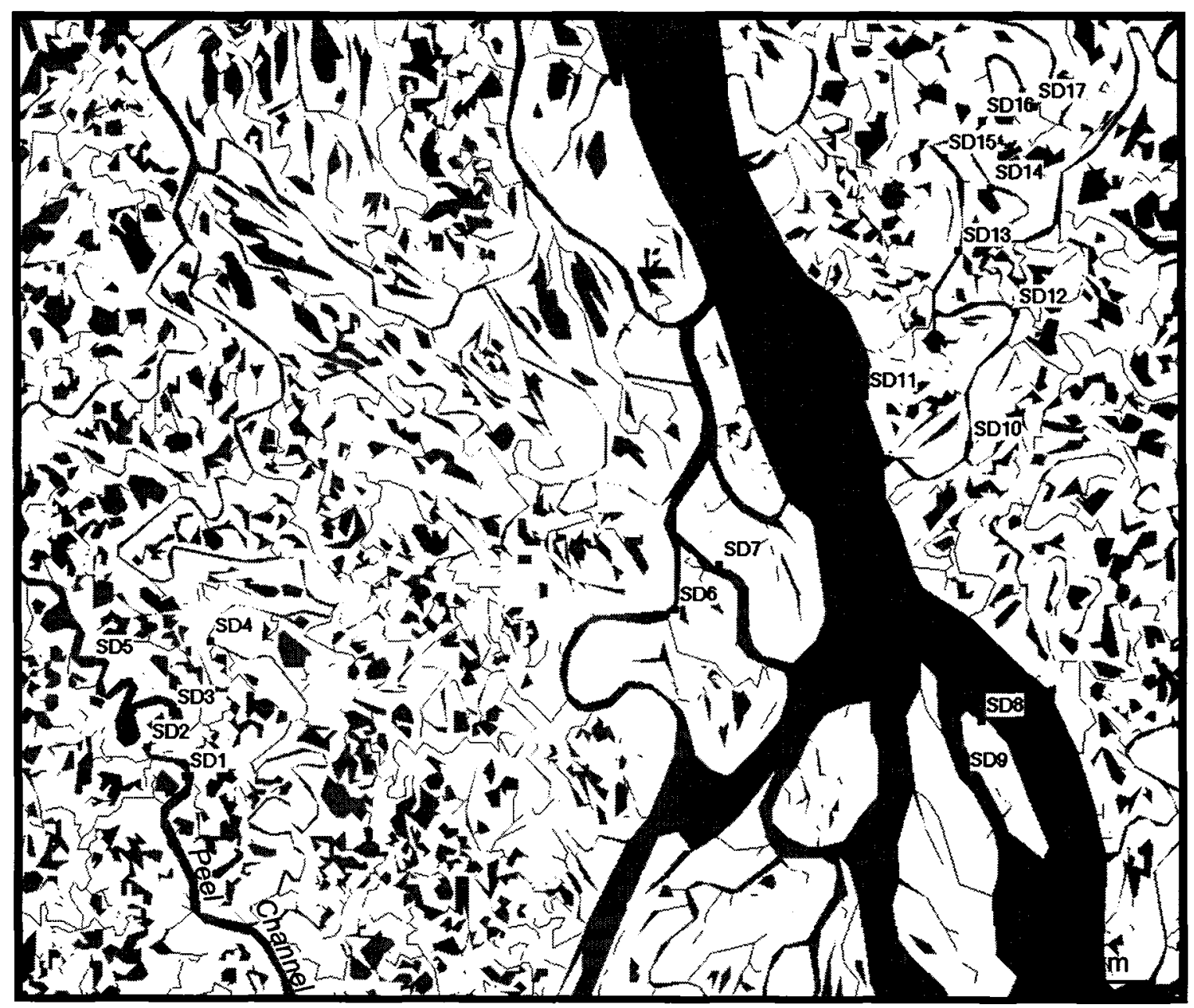

Fig. 3.9 - Transect locations in the southern delta. SD1 to SD5 were located in the western section, SD6 to SD9 were set on alluvial islands on Middle Channel, and SD10 to SD17 were located in the eastern half. 


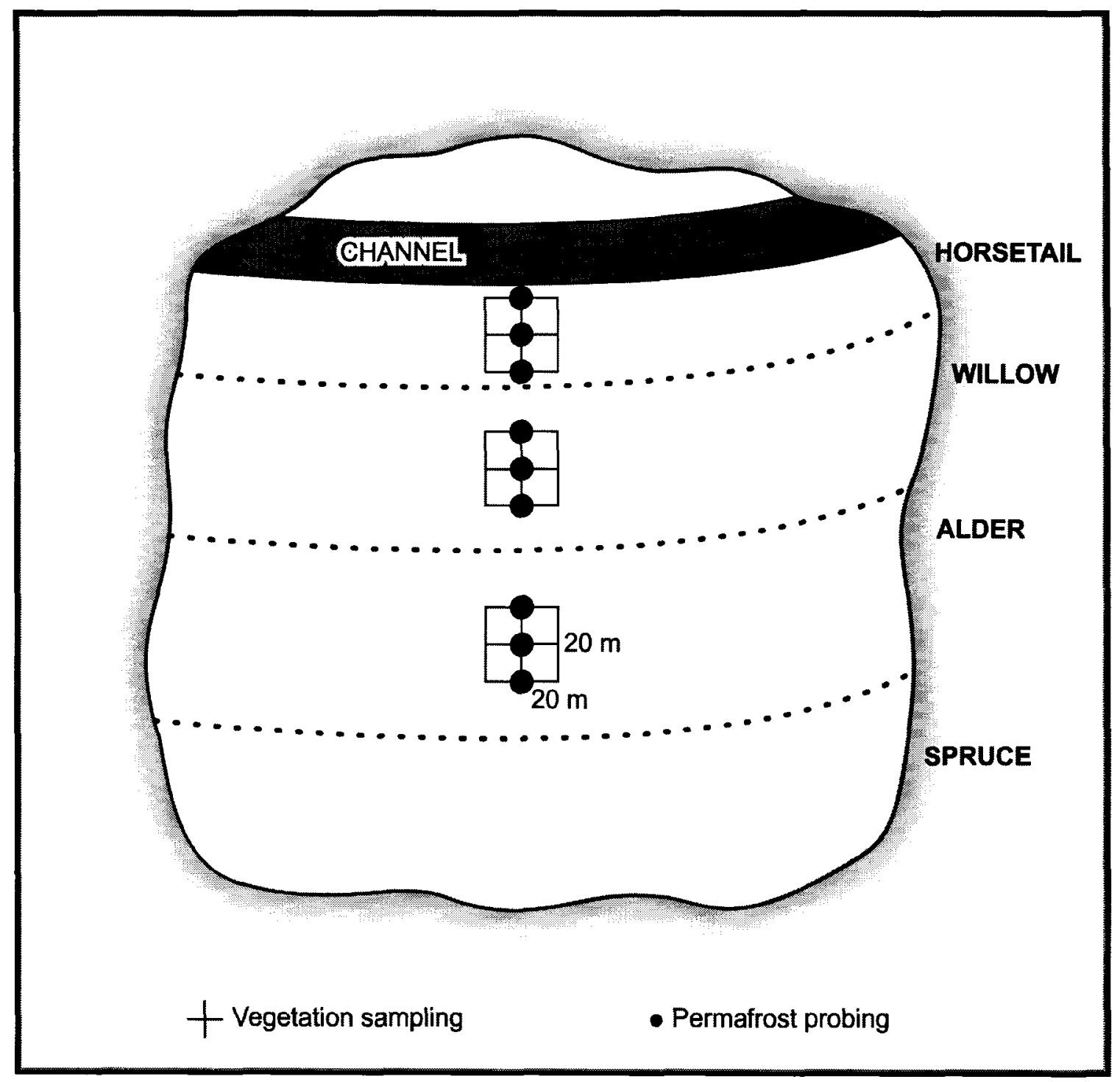

Fig. 3.10 - Near-surface permafrost was probed and vegetation was sampled in $20 \times 20 \mathrm{~m}$ plots along linear transects perpendicular to shorelines crossing several vegetation communities. 
the three layers were set according to Mueller-Dombois and Ellenberg (1974). These limits were also used by Boyes (1991) in his study in the central delta. The herb layer was defined as all plants $<30 \mathrm{~cm}$, including seedlings and saplings of non-herbaceous plants. The shrub layer consisted of all woody plants $>30 \mathrm{~cm}$ with a stem diameter of $<10 \mathrm{~cm}$, and the tree layer consisted of woody plants with a trunk diameter $\geq 10 \mathrm{~cm}$ and at a height of $>1.5 \mathrm{~m}$ (Mueller-Dombois and Ellenberg 1974).

Vegetation was identified at the genus level for shrubs and trees, and at the functional-type level for herbs (Walker 2000). Vegetation sampling was made within generally uniform vegetation-cover plots $20 \times 20 \mathrm{~m}$ in size along two perpendicular $20 \mathrm{~m}$ lines (Fig. 3.10). The corner coordinates for each plot were also recorded by GPS with an accuracy level from 4 to $8 \mathrm{~m}$. The large plot dimension was necessary for the accurate location of the selected areas on satellite imagery. Errors on the order of 0.5-1 pixel usually exist in georeferenced images, in addition to errors in ground location. Consequently, McCoy (2005) suggested a formula to calculate the minimum size of sample plots:

$$
A=P(1+2 L)
$$

where $\mathrm{A}$ is minimum sample size dimension, $\mathrm{P}$ is image pixel dimension, and $\mathrm{L}$ is estimated locational accuracy in number of pixels. With an $L$ value of 0.5 , the minimum sample size dimension for a SPOT-5 image is $20 \times 20 \mathrm{~m}$ or $2 \times 2$ multispectral pixels. McCoy (2005) also recommended selecting a number of pixels in each class that is at least 10 times the number of bands used in developing training statistics, which for this research requires 40 pixels per class per image. The stratified sampling design was applied in this research for the following reasons: i) the ease of application in the field; ii) 
the ability to characterize a variety of vegetation community types over their respective environmental gradients; iii) the ability to ensure relative community homogeneity within sample plots; iv) the ability to ensure plot dimensions identifiable on satellite images; and v) to ensure an adequate number of samples for each class.

\subsubsection{Herb layer measurements}

The two measurements used in the herb layer were presence and frequency. Presence is the ratio of the number of samples in which a plant type was found divided by the total number of samples for a plant community expressed as a percentage. This measured how many sample sites contained a particular plant type and was used as an indication of how often a plant type occurs in a plant community (Mueller-Dombois and Ellenberg 1974). Plant frequency, also expressed as a percentage, is the ratio of the number of times a particular plant type is found divided by the total number of times any plant type is found in each association. This is used to measure the relative dominance of each plant type that was present in a plant association compared with all the plant types present. When these two measures are used together, they provide an indication of how often a plant type is present and how dominant that plant type is in a community. Vegetation richness can also be derived from the frequency measurements and refers to the number of plant types present in a given community.

In each vegetation association, the herb layer was sampled, using the pointintercept method, every $1 \mathrm{~m}$ along the two perpendicular $20 \mathrm{~m}$ lines. Intercept methods were shown as being more expedient to use than other sampling methods while providing comparable reliability and objectivity (Bonham 1989). The point-intercept method 
measures the frequency of occurrence of each plant type, which can be used as an estimate of plant type cover in herbaceous vegetation by dividing the number of interceptions of a plant type by the total number of point intervals used (Bonham 1989). The herb sampling was done by laying a tape on the ground and by counting how often each plant type was recorded along a transect. In the herb layer, plants were grouped into the following functional types: horsetails, wildflowers, grasses, rushes, sedges, mosses, and lichens (Walker 2000).

\subsubsection{Shrub and tree layer measurements}

The shrub and tree layers were sampled using the same two perpendicular $20 \mathrm{~m}$ lines as for the herb layer. Shrubs and trees were sampled using the line-intercept method since this method has proven to be an efficient sampling technique for woody vegetation in mixed-plant communities (Bonham 1989). This is done by keeping a tape at waistheight, and wherever a plant touched the tape along the $20 \mathrm{~m}$ line, its genus and intercept distance were recorded. Plant presence and frequency were measured and calculated in the same manner as for the herb layer. For remote-sensing purposes, observation points under the canopy of a plant were counted as an observation of that plant even though the plant's stem was not itself intercepted (McCoy 2005).

\subsubsection{Leaf-area index (LAI) measurements}

In order to provide a measure of vegetation density and canopy cover, LAI was measured using the LI-COR LAI-2000 plant-canopy analyzer. The LAI-2000 measures "effective LAI" (LAIe), which assumes a random foliage distribution and is less than the 
actual LAI by a clumping index. The clumping index gives the degree of clumping of foliage in the canopy and varies amongst the plant types and conditions. Therefore, the use of LAIe instead of LAI introduces additional variation and uncertainty. Hereafter, LAIe is simply referred to as LAI.

Previous studies of LAI in arctic vegetation showed generally good correspondence between LAI and spectral vegetation indices, especially when examined across broad biomass gradients (Shippert et al. 1995; Walker et al. 2003). The LI-COR LAI-2000 gives an indication of canopy cover based on differences in diffuse radiation above and below the plant canopy. Above- and below-canopy radiation measurements were made with a "fish eye" optical sensor. A $45^{\circ}$ field-of-view shield was used to prevent interference from the observers. All measurements were taken facing away from the Sun. The LAI readings should be taken on cloudy days to prevent problems with reflections in the plant canopy. This was not always possible, so on sunny days a black umbrella was used to shade the sensor from direct sunlight while at the same time providing an unobstructed view of the sky. At each vegetation association, one abovecanopy reading was taken, and six below-canopy readings were taken at random locations within the plot to yield a single LAI value.

\subsubsection{Near-surface permafrost probing}

The ground was probed by using water-jet drilling, to a maximum of $3-\mathrm{m}$ depth, to detect near-surface permafrost in each vegetation association. Since the active-layer thickness does not exceed $1.5 \mathrm{~m}$ where near-surface permafrost is present (Kokelj and Burn 2005b), if unfrozen ground was recorded through to 3-m depth, near-surface 
permafrost was considered absent. In each plot on a transect, the water-jet hole drilled at the centre of the plot was complemented with two other holes, spaced at $10 \mathrm{~m}$ from the central hole (Fig. 3.10). Each vegetation class on a transect was assigned a single nearsurface permafrost presence or absence label based on the rule of majority. No excavation of sediments was required to locate the frost table, since the alluvial surficial material in the delta is well suited for water-jet drilling and probing.

\subsubsection{Ground Control Points}

Ground control points (GCP) were collected in order to georeference the SPOT-5 images. GCPs had an estimated registration error of about $5 \mathrm{~m}$. The major difficulty in collecting GCPs in the Delta was the lack of large artificial structures that would appear distinctively on satellite images. There are numerous fishing and trapping cabins in the central delta but these structures were either too small or too dilapidated to be recognized on SPOT-5 images. Therefore, confluences of small channels were used as GCPs and efforts were made to make sure these GCPs were well spread out within the study area.

\subsubsection{The water-land boundary issue}

Classification of permafrost zones only considers permafrost underlying exposed ground. Thus, the boundary between water bodies and land is an important issue when estimating the exposed ground underlain by permafrost in the Delta. This is especially true in the dynamic environment of the Mackenzie Delta with high spatial and temporal as well as interannual variability in water levels. An idealized definition of shoreline is that it coincides with the physical interface of land and water. In reality, the shoreline 
position changes continually through time because of the dynamic nature of water levels. The shoreline must therefore be considered in a temporal sense, and the time scale chosen will depend on the context of the investigation (Boak and Turner 2005).

The most common shoreline indicator is the high-water line (HWL). Commonly, the HWL is visually determined from aerial photographs by detecting changes in colour or gray tone. However, the interpretation of the HWL has the potential to be a significant source of error for shoreline mapping since the HWL may not appear as a distinct line but instead may appear as a transitional zone. Shoreline indicator features currently used, including the HWL, do not take account of the spatial and temporal influences in shoreline position such as tide or wind effects (Boak and Turner 2005).

In the Mackenzie Delta, given that (1) water level fluctuates on short temporal scales, (2) satellite images are only a snapshot at one point in time, and (3) the fact that fieldwork was spread throughout the summer, there would be discrepancies between what is represented on the satellite images and what was found in the field. For example, for certain sites, Horsetail associations could be submerged in the field but present in the images and vice versa. Since the satellite images were acquired in July 2006 when the water level had stabilized, it was decided to take shorelines as they appear on satellite images as the water-land boundary. This type of shoreline was referred to as an instantaneous shoreline by Boak and Turner (2005). For this research, this instantaneous shoreline was assumed to represent average shoreline conditions.

Shoreline positions at field sites were recorded by GPS. If sampled plots appeared to be submerged on the satellite images, then field data for those particular plots were not included in the image classifications. Changes in shoreline positions were also noted in 
late August and compared to conditions observed in June and July. This comparison may help in assessing the shoreline variability, and whether the instantaneous shoreline used in this research represents average conditions.

\subsection{Concluding remarks}

In the discontinuous permafrost zone, vegetation type may not provide a straightforward indication of the frost characteristics of the ground (Brown 1966). However, in the Delta, environmental conditions such as channel shifting and flood regime affect both plant distributions and the occurrence of taliks. Since vegetation and taliks are coupled through those intermediaries, vegetation characteristics may be used as evidence of near-surface permafrost presence.

To test this hypothesis, permafrost presence was probed and vegetation sampled at sites located in representative regions of the Delta. Despite difficulties in using remote sensing for permafrost mapping in other regions due to undetectable variations in subsurface properties (Leverington and Duguay 1997), its applicability in this research is enhanced, as subsurface properties are comparable throughout the delta. The use of remote sensing allows extrapolation from field results and the estimation of the extent of near-surface permafrost from maps of classified vegetation associations. 


\section{CHAPTER FOUR}

\section{VEGETATION AND NEAR-SURFACE PERMAFROST}

\subsection{Introduction}

The range of environmental conditions in the Mackenzie Delta provides opportunities to investigate the relations between vegetation communities and the presence of near-surface permafrost. Previous work in the Delta on point-bar environments (Gill 1972), vegetation succession (Gill 1973; Pearce 1998), sedimentation (Pearce 1994), and permafrost (Smith 1975) present a context for interpreting the results in this study. This chapter examines the physical characteristics of the study sites as well as shoreline variations observed at these sites. The structure and composition of each vegetation community, and the relations between these communities and the presence of near-surface permafrost are determined. In addition, leaf-area index (LAI) variations between these vegetation associations are investigated.

\subsection{Physical characteristics of the study sites}

\subsubsection{Southern delta}

Study sites in the southern delta (SD1 to SD17) were located about $40 \mathrm{~km}$ from Point Separation and $160 \mathrm{~km}$ from the Beaufort Sea (Fig. 3.9). The southern delta was primarily investigated from June 14 to June 29, 2006 and water levels were still relatively high in this period, submerging many Horsetail zones. Since the lower parts of several investigated Horsetail zones were under water, vegetation was sampled and near-surface permafrost was probed in the emerged parts (Fig. 4.1). The effect of recent spring 


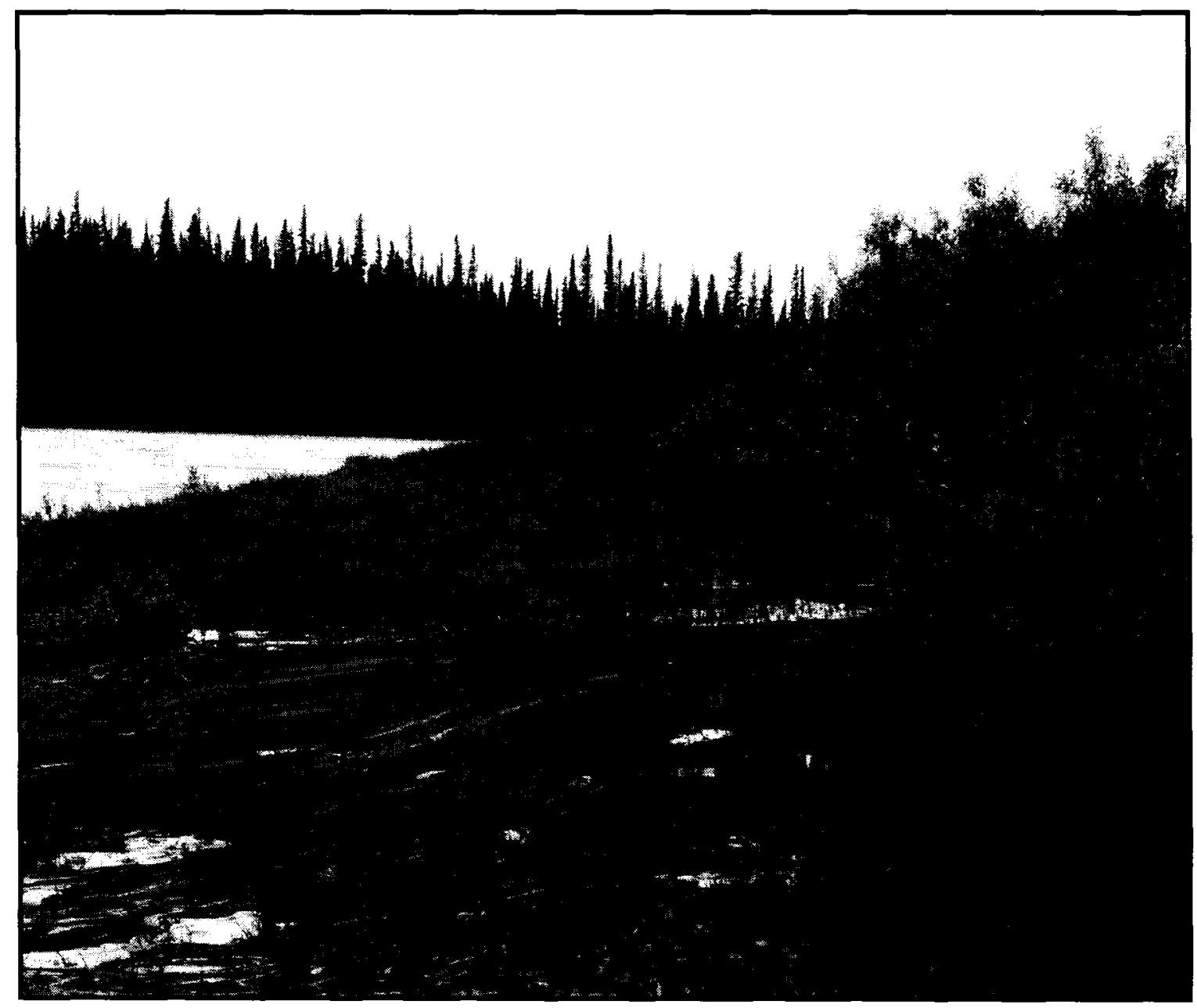

Fig. 4.1 - SD17 was investigated on June 27, 2006. The lower part of the Horsetail zone was under water but the area of the emergent part was still large enough for vegetation sampling and permafrost probing. The Willow-horsetail zone is next in the succession sequence and spruce forest occupied the cut bank opposite to the SD17 point bar. 
flooding was observed, for as much as $10 \mathrm{~cm}$ of silt was on the ground at SD11, close to Middle Channel, and the herb layer was covered by sediment at many sites (Fig. 4.2).

Study sites SD6 to SD9 were on alluvial islands in Middle Channel just $30 \mathrm{~km}$ north of Point Separation. Here, the channel is wide and not confined by steep bedrock walls, as between Arctic Red River and Point Separation. Stream velocity is also lower and, thus coarser particles drop out, so that these alluvial islands are giant sand and mud bars (Pearce 1986). Large areas of these islands are sufficiently elevated by sediment deposition that vegetation has colonized and stabilized their surfaces (Mackay 1963). Alders and willows dominate the elevated parts and large areas of unvegetated sandflats on the downstream sides of the islands are not exposed until mid-summer (Pearce 1994).

\subsubsection{Central delta}

Most of the study sites in the central delta were investigated in July 2006. West of Middle Channel, study sites CD18 to CD24 were set near Taylor and Nicoluk channels, $10 \mathrm{~km}$ north and east of Aklavik and $100 \mathrm{~km}$ from the Beaufort Sea. CD25 to CD31 were located in the Napoiak Channel vicinity while CD32 and CD33 were set in the Amagokvik Channel-Axel Creek area (Fig. 3.8). These study sites were characteristic of the central delta with levees only 3 to $5 \mathrm{~m}$ in elevation (Pearce 1994). White-spruce forest was found on the higher elevations of the delta plain, and willows and alders dominated sites flooded annually.

East of Middle Channel, study sites CD34 and CD35 were in the vicinity of Chicksi Channel, between East Channel and Middle Channel, $50 \mathrm{~km}$ north of Inuvik (Fig. 3.8). Vegetation patterns, ground temperature and permafrost distribution were 


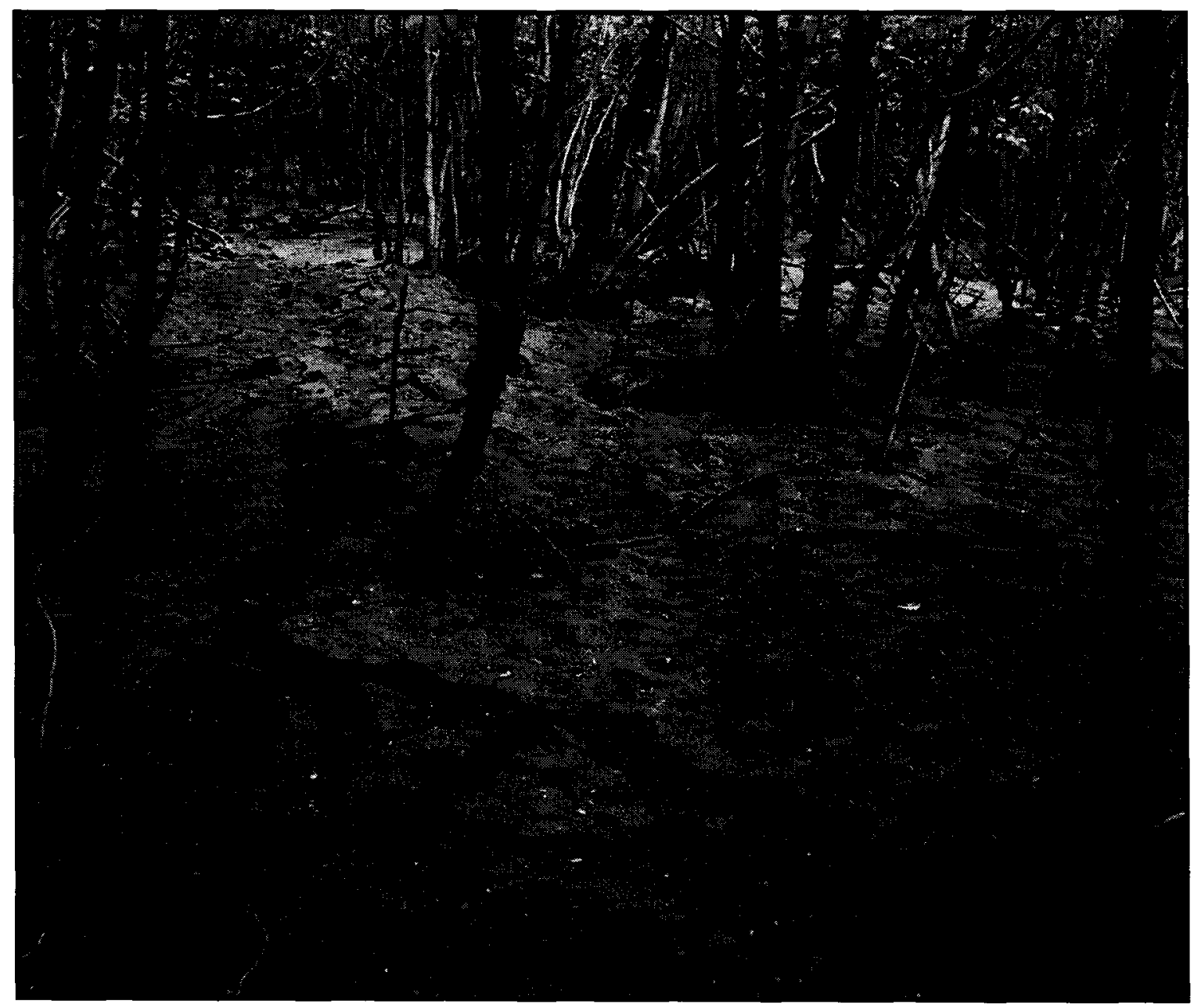

Fig. 4.2 - SD11 was investigated on June 26, 2006. As much as $10 \mathrm{~cm}$ of silt was deposited by the recent spring flooding in the Alder zone of this site. 
thoroughly studied in this area by Gill (1972), Smith (1976), and Pearce (1994). This study area is $25 \mathrm{~km}$ south of tree line, and the white-spruce forests on the delta plain are more open and the trees more stunted than areas to the south.

\subsubsection{Northern delta}

The majority of study sites in the northern delta (ND36 to ND43, ND46 to ND48 and ND51) were located within the Kendall Island Bird Sanctuary, between Niglintgak Island and Taglu Island (Fig. 3.7). The sanctuary is bounded by Mackenzie Bay to the north, Harry Channel to the east, and Middle Channel to the south and west. The rest of the study sites were located in the southwestern part of the northern delta, between Arvoknar Channel and Middle Channel (ND44, ND45, ND49, ND50 and ND52). The surface covers in the area are low-shrub tundra consisting of mostly willow and alder species; mosses and lichens; and tall shrubs (Pearce 1994). Much of the northern delta can be flooded throughout the summer by storm and tidal surges of the Beaufort Sea. The northern delta was primarily investigated in August 2006.

\subsection{Shoreline variations during summer 2006}

Since sites in the southern delta were primarily investigated in early summer, shoreline variations between June and late August were greatest in that region. All 17 sites in the southern delta experienced horizontal shoreline variations ranging from $1 \mathrm{~m}$ to $25 \mathrm{~m}$ with an average of $12 \mathrm{~m}$. At a few sites, such as SD10, the newly exposed ground was bare in late August, but at other sites, such as SD13, it was covered with horsetails (Fig. 4.3). Since SPOT-5 images were captured in July, it could be assumed that the 
shoreline variability between June and July in the southern delta was approximately the size of a multispectral pixel $(10 \mathrm{~m})$.

Differences in shoreline positions between July and August in the central delta averaged $4 \mathrm{~m}$, varying between $2 \mathrm{~m}$ and $6 \mathrm{~m}$. Northern delta sites were studied in August, after the satellite image capture, and as a result no estimation of shoreline variations was possible. However, in late August, a storm surge was observed and several Willowhorsetail plots were flooded. This indicated that shoreline position in the northern delta can vary up to about $30 \mathrm{~m}$ with short-duration storm surges.

This assessment of shoreline variations indicates that the instantaneous shoreline captured by SPOT- 5 in July may be used in this research to represent average conditions in the delta. Shoreline variations from June to August were about the size of a pixel.

\subsection{Vegetation composition and structure}

In order to determine the dominant vegetation type in each plant community, the dominant vegetation definition from the National Vegetation Classification Standard (NVCS) was used. The NVCS (1997) defines dominant vegetation as the uppermost canopy vegetation with a percentage cover above $25 \%$. If no vegetation has a cover above $25 \%$ then dominant vegetation is the one with the highest percentage cover. In cases of a tie, dominant vegetation is defined as the uppermost canopy vegetation with the highest percentage cover. Tables 4.1-4.3 indicate the structure and composition of each vegetation association for the three delta regions. The composition and structure were distinct between vegetation associations at each study site. 
a)
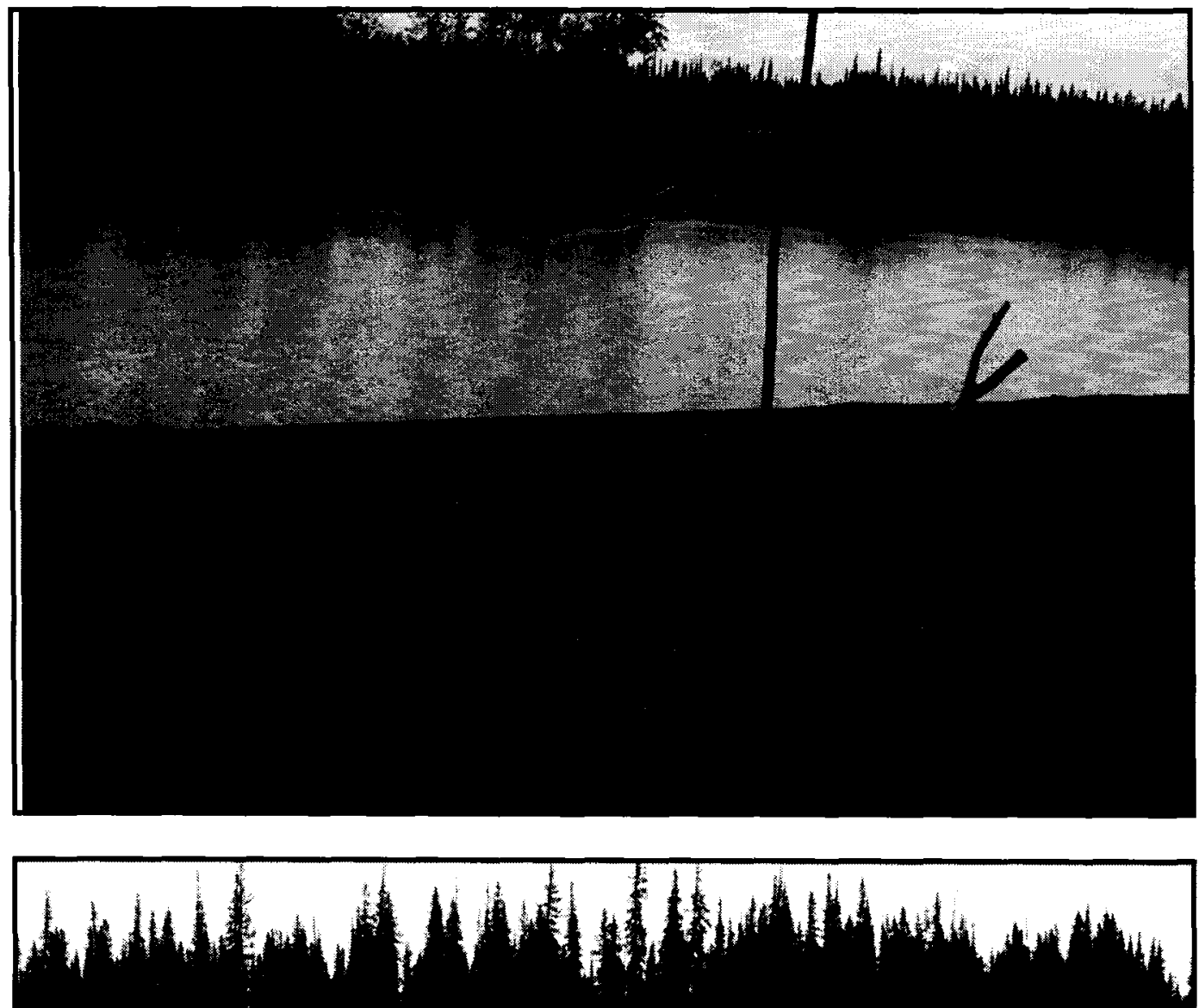

b)

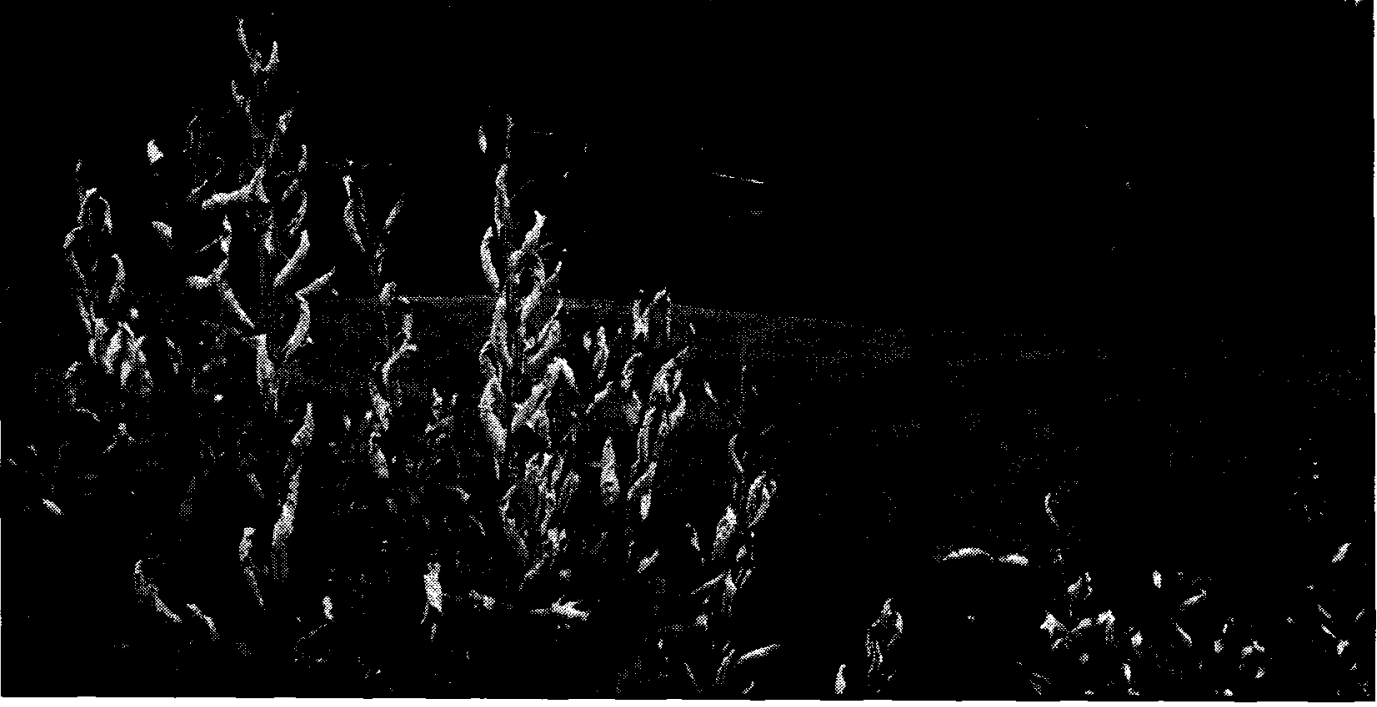

Fig. 4.3 - Shoreline position was marked at (a) SD10 and (b) SD13 in June 2006. In August, water levels dropped revealing newly exposed bare ground at SD10 and horsetail-covered ground at SD13. 
Table 4.1 - Vegetation composition and structure in the southern delta. Presence and frequency are given in percentages. Functional types used in the herbs layer are based on Walker (2000) and Johnson et al. (1995).

\begin{tabular}{|c|c|c|c|c|c|c|}
\hline \multirow[t]{2}{*}{ Layer } & \multicolumn{2}{|c|}{ Horsetail $(n=8)$} & \multicolumn{2}{|c|}{ Willow-horsetail $(\mathrm{n}=19)$} & \multicolumn{2}{|c|}{ Alder $(\mathrm{n}=25)$} \\
\hline & Plants & $\begin{array}{l}\text { Presencel } \\
\text { Frequency }\end{array}$ & Plants & $\begin{array}{l}\text { Presencel } \\
\text { Frequency }\end{array}$ & Plants & $\begin{array}{l}\text { Presencel } \\
\text { Frequency }\end{array}$ \\
\hline Herbs & horsetail & $100 / 100$ & $\begin{array}{l}\text { horsetail } \\
\text { grasses } \\
\text { wildflowers }\end{array}$ & $\begin{array}{c}100 / 89 \\
39 / 7 \\
17 / 4\end{array}$ & $\begin{array}{l}\text { horsetail } \\
\text { wildflowers } \\
\text { grasses } \\
\text { mosses } \\
\text { saplings }\end{array}$ & $\begin{array}{c}92 / 55 \\
84 / 32 \\
32 / 5 \\
36 / 4 \\
12 / 2\end{array}$ \\
\hline Shrubs & willow & $33 / 100$ & $\begin{array}{l}\text { willow } \\
\text { alder }\end{array}$ & $\begin{array}{c}100 / 95 \\
44 / 5\end{array}$ & $\begin{array}{l}\text { alder } \\
\text { willow } \\
\text { poplar }\end{array}$ & $\begin{array}{c}100 / 77 \\
84 / 19 \\
8 / 2\end{array}$ \\
\hline Trees & & & willow & $22 / 100$ & $\begin{array}{l}\text { alder } \\
\text { willow } \\
\text { poplar } \\
\text { spruce } \\
\end{array}$ & $\begin{array}{c}92 / 57 \\
72 / 29 \\
24 / 8 \\
16 / 6 \\
\end{array}$ \\
\hline $\begin{array}{l}\text { Plants } \\
\text { richness }\end{array}$ & & 2 & & & & \\
\hline $\begin{array}{l}\text { Median } \\
\text { LAI }\end{array}$ & & \pm 0.07 & 0.9 & .11 & 2.43 & 0.09 \\
\hline $\begin{array}{l}\text { Mean } \\
\text { width }\end{array}$ & & $\mathrm{m}$ & & & & \\
\hline $\begin{array}{l}\text { Height } \\
\text { Herbs } \\
\text { Shrubs } \\
\text { Trees } \\
\end{array}$ & & $\begin{array}{l}\mathrm{cm} \\
\mathrm{cm}\end{array}$ & & & & \\
\hline
\end{tabular}


Table 4.2 - Vegetation composition and structure in the central delta. Presence and frequency are given in percentages. Functional types used in the herbs layer are based on Walker (2000) and Johnson et al. (1995).

\begin{tabular}{|c|c|c|c|c|c|c|c|c|}
\hline \multirow[t]{2}{*}{ Layer } & \multicolumn{2}{|c|}{ Horsetail $(n=14)$} & \multicolumn{2}{|c|}{ Willow-horsetail $(n=18)$} & \multicolumn{2}{|c|}{ Alder $(n=19)$} & \multicolumn{2}{|c|}{ Willow-bearberry $(n=7)$} \\
\hline & Plants & $\begin{array}{l}\text { Presencel } \\
\text { Frequency }\end{array}$ & Plants & $\begin{array}{l}\text { Presencel } \\
\text { Frequency }\end{array}$ & Plants & $\begin{array}{l}\text { Presencel } \\
\text { Frequency }\end{array}$ & Plants & $\begin{array}{l}\text { Presencel } \\
\text { Frequency }\end{array}$ \\
\hline Herbs & $\begin{array}{l}\text { horsetail } \\
\text { grasses }\end{array}$ & $\begin{array}{c}100 / 96 \\
29 / 4\end{array}$ & $\begin{array}{l}\text { horsetail } \\
\text { grasses } \\
\text { wildflowers } \\
\text { mosses }\end{array}$ & $\begin{array}{c}100 / 70 \\
56 / 5 \\
72 / 23 \\
11 / 2\end{array}$ & $\begin{array}{l}\text { horsetail } \\
\text { grasses } \\
\text { wildflowers } \\
\text { mosses } \\
\text { saplings }\end{array}$ & $\begin{array}{c}100 / 43 \\
53 / 6 \\
95 / 30 \\
79 / 16 \\
21 / 5\end{array}$ & $\begin{array}{l}\text { horsetail } \\
\text { grasses } \\
\text { wildflowers } \\
\text { mosses } \\
\text { saplings } \\
\text { lichens }\end{array}$ & $\begin{array}{c}86 / 29 \\
43 / 1 \\
100 / 47 \\
100 / 16 \\
71 / 5 \\
29 / 2\end{array}$ \\
\hline Shrubs & willow & $43 / 100$ & $\begin{array}{l}\text { willow } \\
\text { alder }\end{array}$ & $\begin{array}{c}100 / 92 \\
56 / 8\end{array}$ & $\begin{array}{l}\text { willow } \\
\text { alder } \\
\text { poplar }\end{array}$ & $\begin{array}{c}95 / 23 \\
100 / 70 \\
16 / 2\end{array}$ & $\begin{array}{l}\text { willow } \\
\text { alder } \\
\text { poplar }\end{array}$ & $\begin{array}{c}100 / 78 \\
86 / 7 \\
29 / 11\end{array}$ \\
\hline Trees & & & willow & $39 / 100$ & $\begin{array}{l}\text { willow } \\
\text { alder } \\
\text { poplar }\end{array}$ & $\begin{array}{c}68 / 34 \\
68 / 43 \\
16 / 7 \\
\end{array}$ & $\begin{array}{l}\text { willow } \\
\text { poplar } \\
\text { spruce }\end{array}$ & $\begin{array}{c}29 / 29 \\
43 / 37 \\
29 / 6 \\
\end{array}$ \\
\hline $\begin{array}{l}\text { Plants } \\
\text { richness }\end{array}$ & \multicolumn{2}{|c|}{3} & \multicolumn{2}{|c|}{ 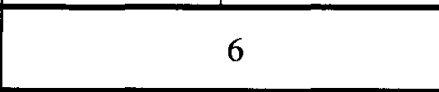 } & \multicolumn{2}{|l|}{ 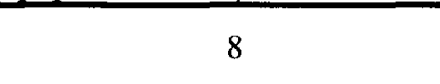 } & \multicolumn{2}{|c|}{10} \\
\hline $\begin{array}{l}\text { Median } \\
\text { LAI } \\
\end{array}$ & \multicolumn{2}{|c|}{$0.37 \pm 0.08$} & \multicolumn{2}{|c|}{$1.46 \pm 0.19$} & \multicolumn{2}{|c|}{$2.90 \pm 0.16$} & \multicolumn{2}{|c|}{$1.10 \pm 0.10$} \\
\hline Mean width & \multicolumn{2}{|c|}{$24 \mathrm{~m}$} & \multicolumn{2}{|c|}{$40 \mathrm{~m}$} & \multicolumn{2}{|c|}{$50 \mathrm{~m}$} & \multicolumn{2}{|c|}{$25 \mathrm{~m}$} \\
\hline $\begin{array}{l}\text { Height } \\
\text { Herbs } \\
\text { Shrubs } \\
\text { Trees } \\
\end{array}$ & \multicolumn{2}{|c|}{$\begin{array}{l}24 \mathrm{~cm} \\
76 \mathrm{~cm}\end{array}$} & \multicolumn{2}{|c|}{$\begin{array}{c}23 \mathrm{~cm} \\
4 \mathrm{~m} \\
8 \mathrm{~m} \\
\end{array}$} & \multicolumn{2}{|c|}{$\begin{array}{c}20 \mathrm{~cm} \\
3 \mathrm{~m} \\
6 \mathrm{~m} \\
\end{array}$} & \multicolumn{2}{|c|}{$\begin{array}{c}21 \mathrm{~cm} \\
3 \mathrm{~m} \\
5 \mathrm{~m} \\
\end{array}$} \\
\hline
\end{tabular}


Table 4.3 - Vegetation composition and structure in the northern delta. Presence and frequency are given in percentages. Functional types used in the herbs layer are based on Walker (2000) and Johnson et al. (1995).

\begin{tabular}{|c|c|c|c|c|c|c|c|c|}
\hline \multirow[t]{2}{*}{ Layer } & \multicolumn{2}{|c|}{ Horsetail $(\mathrm{n}=8)$} & \multicolumn{2}{|c|}{ Sedge $(n=10)$} & \multicolumn{2}{|c|}{ Willow-horsetail $(\mathrm{n}=12)$} & \multicolumn{2}{|c|}{ Short willows $(n=15)$} \\
\hline & Plants & $\begin{array}{l}\text { Presencel } \\
\text { Frequency } \\
\end{array}$ & Plants & $\begin{array}{l}\text { Presencel } \\
\text { Frequency } \\
\end{array}$ & $\overline{P l a n t s}$ & $\begin{array}{l}\text { Presencel } \\
\text { Frequency }\end{array}$ & Plants & $\begin{array}{l}\text { Presencel } \\
\text { Frequency }\end{array}$ \\
\hline Herbs & $\begin{array}{l}\text { horsetail } \\
\text { grasses } \\
\text { sedges }\end{array}$ & $\begin{array}{c}100 / 91 \\
25 / 4 \\
25 / 5\end{array}$ & $\begin{array}{l}\text { horsetail } \\
\text { grasses } \\
\text { wildflowers } \\
\text { sedges }\end{array}$ & $\begin{array}{c}50 / 12 \\
40 / 5 \\
10 / 2 \\
100 / 81\end{array}$ & $\begin{array}{l}\text { horsetail } \\
\text { grasses } \\
\text { wildflowers } \\
\text { mosses } \\
\text { sedges }\end{array}$ & $\begin{array}{c}100 / 49 \\
67 / 9 \\
92 / 18 \\
83 / 7 \\
75 / 17\end{array}$ & $\begin{array}{l}\text { horsetail } \\
\text { grasses } \\
\text { wildflowers } \\
\text { mosses } \\
\text { sedges } \\
\text { rushes }\end{array}$ & $\begin{array}{c}100 / 43 \\
94 / 22 \\
94 / 14 \\
81 / 13 \\
31 / 5 \\
25 / 2\end{array}$ \\
\hline Shrubs & & & willow & $30 / 100$ & willow & $100 / 100$ & $\begin{array}{l}\text { willow } \\
\text { alder }\end{array}$ & $\begin{array}{c}100 / 99 \\
13 / 1\end{array}$ \\
\hline $\begin{array}{l}\text { Plants } \\
\text { richness }\end{array}$ & \multicolumn{2}{|c|}{3} & \multicolumn{2}{|c|}{5} & \multicolumn{2}{|c|}{6} & \multicolumn{2}{|c|}{8} \\
\hline $\begin{array}{l}\text { Median } \\
\text { LAI }\end{array}$ & \multicolumn{2}{|c|}{$0.07 \pm 0.04$} & \multicolumn{2}{|c|}{$1.09 \pm 0.11$} & \multicolumn{2}{|c|}{$1.37 \pm 0.15$} & \multicolumn{2}{|c|}{$1.27 \pm 0.11$} \\
\hline $\begin{array}{l}\text { Mean } \\
\text { width }\end{array}$ & \multicolumn{2}{|c|}{$26 \mathrm{~m}$} & \multicolumn{2}{|c|}{$23 \mathrm{~m}$} & \multicolumn{2}{|c|}{$40 \mathrm{~m}$} & \multicolumn{2}{|c|}{-} \\
\hline $\begin{array}{l}\text { Height } \\
\text { Herbs } \\
\text { Shrubs }\end{array}$ & \multicolumn{2}{|c|}{$23 \mathrm{~cm}$} & \multicolumn{2}{|c|}{$\begin{array}{l}26 \mathrm{~cm} \\
50 \mathrm{~cm}\end{array}$} & \multicolumn{2}{|c|}{$\begin{array}{c}20 \mathrm{~cm} \\
3 \mathrm{~m}\end{array}$} & \multicolumn{2}{|c|}{$\begin{array}{l}19 \mathrm{~cm} \\
60 \mathrm{~cm}\end{array}$} \\
\hline
\end{tabular}




\subsubsection{Horsetail community}

Horsetail communities were often narrow in width with a mean of less than $30 \mathrm{~m}$. The narrower width observed in the southern delta was probably due to the early summer sampling when the lower part of these communities was still under water.

Horsetail was present in all sampling plots and provided a ground cover of over $60 \%$ (Figs. 4.4a, 4.5a, and 4.6a). In the herb layer, grasses and sedges could also be found at a few sites but the mean frequency was very low. Non-vegetative cover types in these communities were litter and bare soil. Litter consisted mainly of dead horsetail plants, although driftwood was found at a few sites. In the shrub layer, sparse and low willow shrubs could be found at approximately $40 \%$ of the sampled sites. However, willow shrubs provided less than $8 \%$ of the canopy cover. Therefore, herbaceous horsetail is the dominant vegetation according to NVCS (1997).

\subsubsection{Willow-horsetail community}

Willow-horsetail communities were also relatively narrow in width with a mean value of less than $40 \mathrm{~m}$. In the herb layer, horsetails were dominant (Figs. $4.4 \mathrm{~b}, 4.5 \mathrm{~b}$, and 4.6b). Grasses, wildflowers, sedges and mosses were also present in this layer but provided less than $25 \%$ ground cover. Since the southern delta was sampled in June, just after spring flooding, bare soil consisting of silty sediments represented an important non-vegetative ground cover. Litter was also present, and was composed mainly of dead willow bark and senescent horsetail. The shrub layer was dominated by willows and, in the southern and central delta, alders were also present with a mean canopy cover of $5 \%$. 


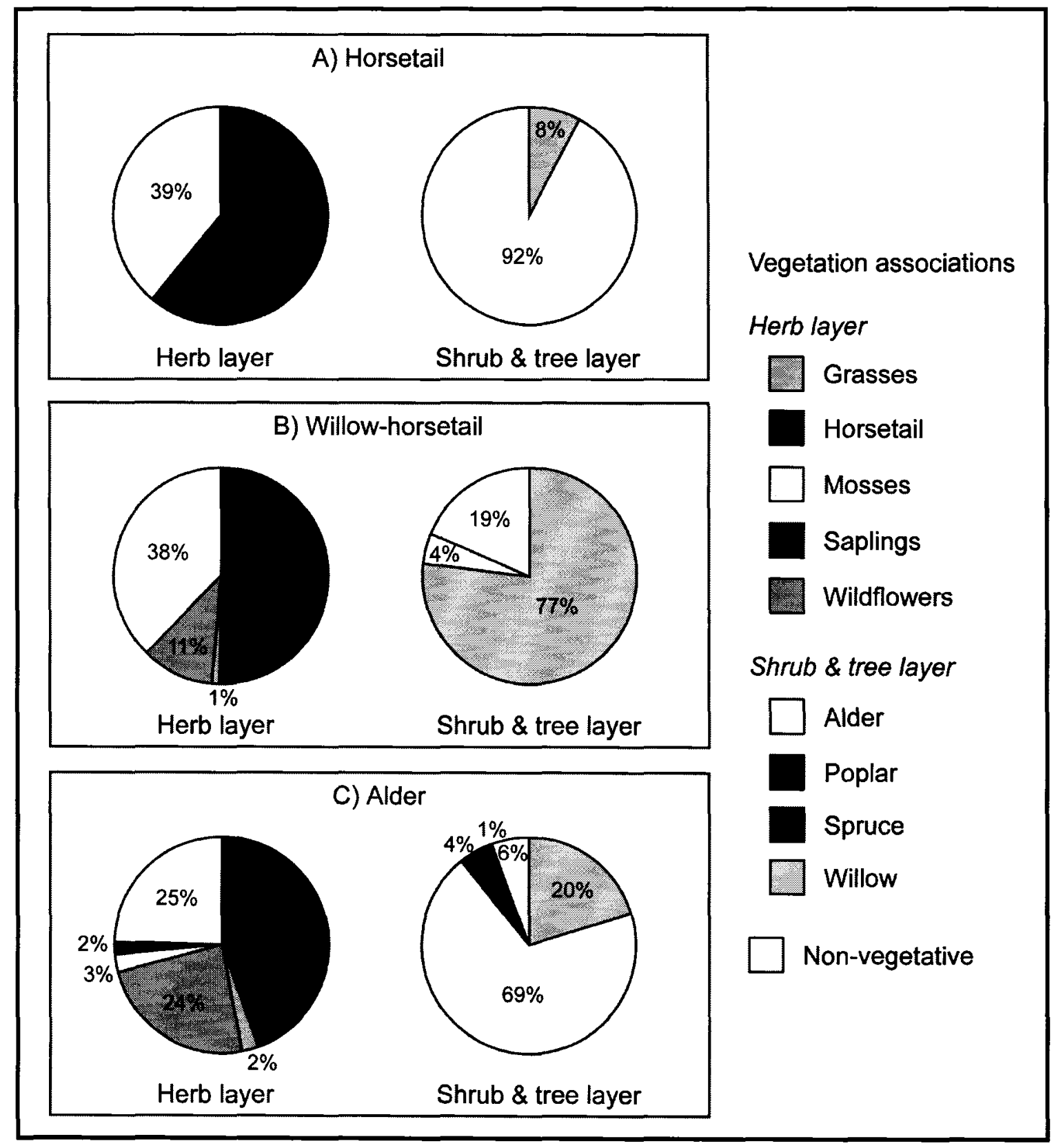

Fig. 4.4 - Ground and canopy cover in a) Horsetail; b) Willow-horsetail; and c) Alder vegetation associations in the southern delta. Percent cover of an herbaceous functional type $=$ (number of point intercepts / total points) $\times 100$. Percent cover of a shrub/tree genus $=($ total intercepted distance $/$ tape length $) \times 100$ (Bonham 1989). 


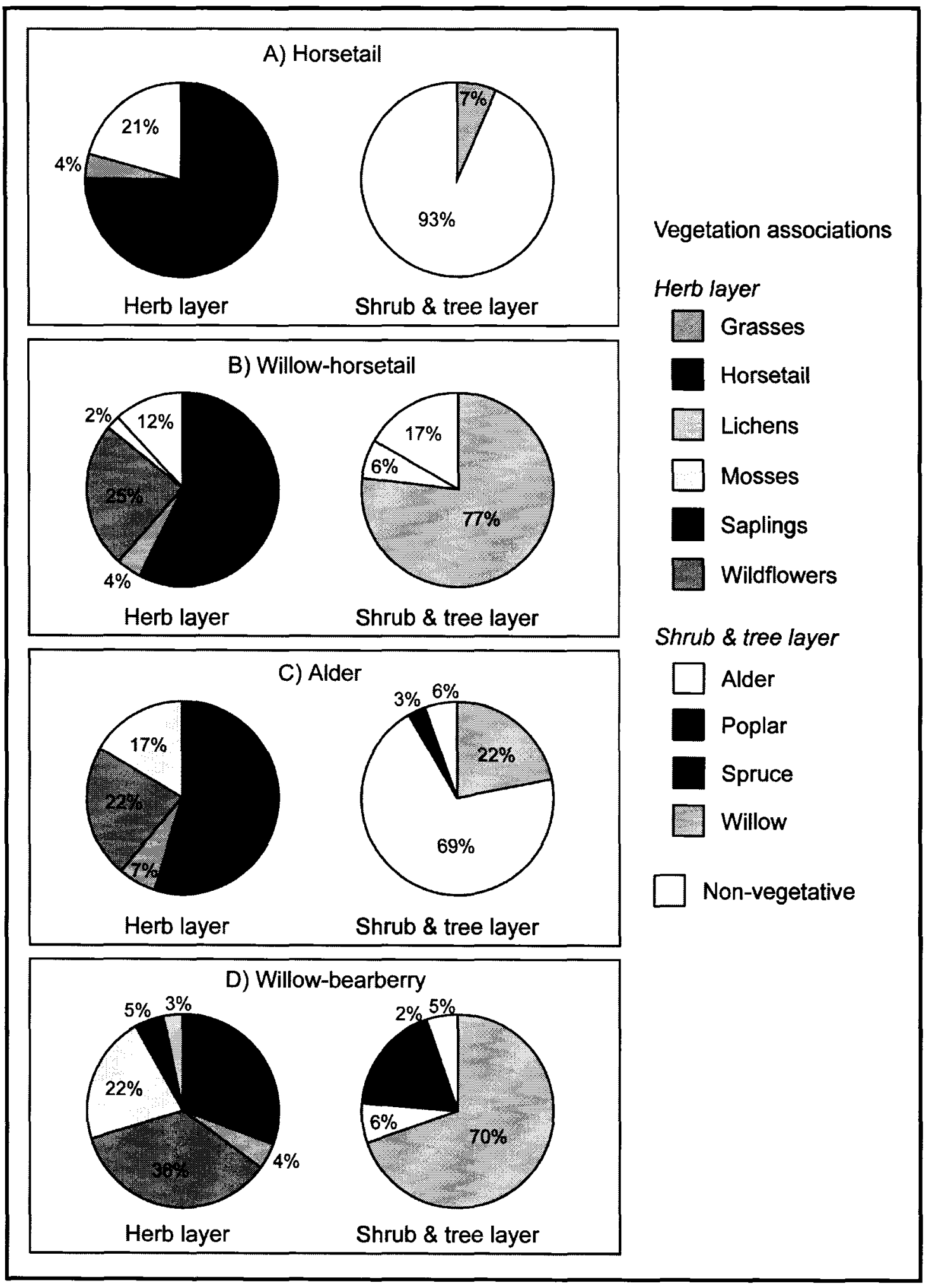

Fig. 4.5 - Ground and canopy cover in a) Horsetail; b) Willow-horsetail; c) Alder; and d) Willow-bearberry vegetation associations in the central delta. 


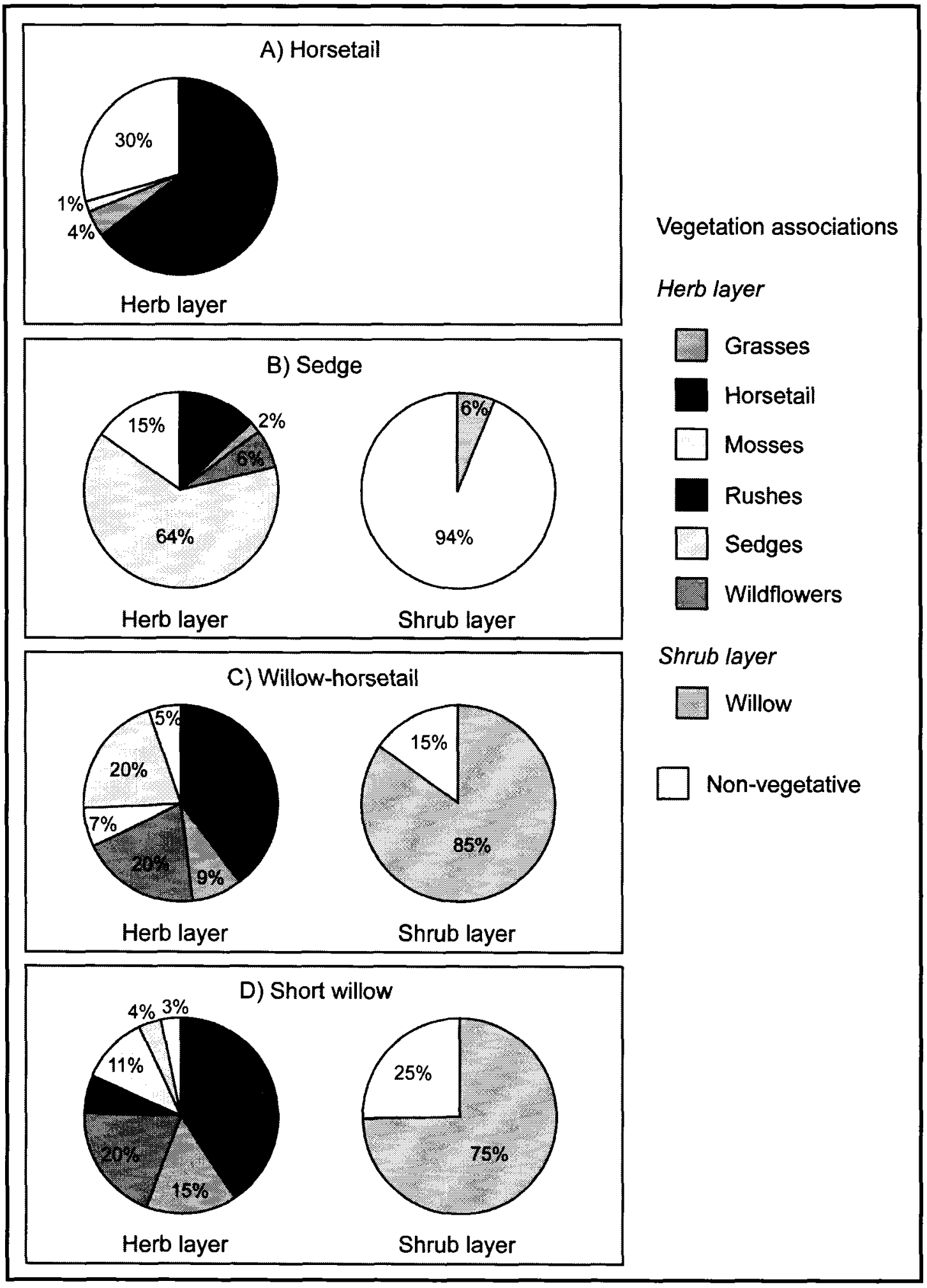

Fig. 4.6 - Ground and canopy cover in a) Horsetail; b) Sedge; c) Willow-horsetail; and d) Short willow vegetation associations in the northern delta. 


\subsubsection{Alder community}

Alder represent a long-term average of low fluvial activity as well as marking the height of average floods (Pearce 1994). Alder communities were found only in the southern and central delta and had a width above $50 \mathrm{~m}$. In the northern delta, sparse alder shrubs were found within Short willow communities and they only provided a very small percentage of the canopy cover $(1 \%)$. The ground cover of Alder communities was also more diverse than in Horsetail and Willow-horsetail communities.

In the herb layer, horsetails were dominant and accounted for $50 \%$ of the ground cover (Figs. $4.4 \mathrm{c}$ and $4.5 \mathrm{c}$ ). Wildflowers, mosses, grasses, and saplings were the other vegetative ground cover types in this layer. Mosses and saplings were virtually absent in the Horsetail and Willow-horsetail communities. Their presence in the Alder communities provided another indication of the lower flooding and sedimentation rates occurring there. Non-vegetative ground cover consisted of bare ground as well as alder bark and dead alder leaves on the soil surface.

In the shrub layer, alders were dominant and present at all sampling sites. Alder shrubs and trees were responsible for a mean canopy cover of $69 \%$. Willows were also an important component with a presence above $70 \%$. However, willows provided a canopy cover of less than $22 \%$. The Alder community is generally one step before spruce forests in the delta's plant successional sequence. The presence of spruce trees and saplings at a few sites may reflect the ecotonal aspect of a community in the process of succeeding to a spruce community. 


\subsubsection{Willow-bearberry community}

In the central delta, a distinct vegetation community not mentioned in the literature was found at 6 of the 18 sampling sites. The Willow-bearberry community was found to be located one step after the Willow-horsetail community in the plant successional sequence and had a mean width of $25 \mathrm{~m}$. This community also had the highest plant richness (10) of all sampled vegetation associations.

In the herb layer, horsetails and mosses had a significant presence (Fig. 4.5d). However, the dominant vegetation type in this layer was wildflowers with a ground cover of $36 \%$. Although bearberry was classified by Johnson et al. (1995) as a shrub, it is lumped in the wildflowers category here given its short stature $(7-10 \mathrm{~cm}$ tall). Bearberry, dominant in the wildflowers category, often forms mats with $50-100 \mathrm{~cm}$ long flexible rooting branches. It also has small pinkish to white flowers in drooping clusters at branch tips. The presence of bearberries, spruce saplings, and lichens was an indication of a well-drained site with lower flooding and sedimentation rates (Johnson et al. 1995).

In the shrub layer, willows were dominant with a mean canopy cover of $70 \%$. Alders, poplars and spruce trees were also present. Woody-plants in this community had an estimated mean height of $3 \mathrm{~m}$ with a maximum value of $5 \mathrm{~m}$.

\subsubsection{Sedge community}

Sedge communities were only found in the northern delta and occupied lowelevation areas close to shorelines with a mean width of $23 \mathrm{~m}$. At sites where a Sedge community was found, it replaced the typical Horsetail emergent community. Annual sedimentation into this community, $2-5 \mathrm{~cm} / \mathrm{yr}$, is low compared to sedimentation in 
Horsetail communities, 2-10 cm/yr (Pearce 1998). This could indicate that sites where a Sedge community was found instead of a Horsetail community are locations with comparatively high elevation and less flooding.

In the herb layer, sedges were dominant with a ground cover of $64 \%$ (Fig. 4.6b). Horsetails, wildflowers and grasses were the other vegetation present. Non-vegetative ground cover was mainly organic litter consisting of dead herbaceous vegetation. Since Sedge communities were merging into willow-dominated communities at slightly higher elevations, sparse willow shrubs were also found in $30 \%$ of the sampled sites.

\subsubsection{Short willow community}

Short willow communities were also only found in the northern delta and were found located one step after the Willow-horsetail community in the plant successional sequence. This vegetation association could also be considered as the climax community in the northern delta since it was furthest away from river channels. It also had the greatest plant richness in the northern delta with 8 different vegetation types. The Short willow communities were wet meadows where flooding could be prolonged but annual sedimentation was minimal. This association was also referred as Richardson's willowhorsetail by Pearce (1998). Richardson's willow is a tundra willow and does not appear able to produce adventitious roots to survive much alluvium deposition. It is stunted at 0.5-1.2 $\mathrm{m}$ tall with intertwining branches creating a dense cover (Fig. 4.7) (Pearce 1998).

The herb layer was dominated by horsetails with a mean ground cover of $41 \%$ (Fig. 4.6d). Grasses, wildflowers, sedges, rushes, and mosses were also noticeably present. Non-vegetative ground cover observed was mainly dead leaves. In the shrub 
layer, willows were dominant. Short willows were present at all sampled sites and had a canopy cover of $75 \%$. Sparse alder shrubs were also present at $13 \%$ of sampled sites but provided only about $1 \%$ of the canopy cover.

\subsubsection{Spruce forests}

Spruce forests were not the focus of this research since the presence of permafrost is ubiquitous there with thin active-layer thicknesses (Smith 1975; Kokelj and Burn 2004). To validate remote sensing data, locations of 8 spruce forests in the southern delta and 10 in the central delta were recorded by GPS.

\subsection{Leaf-area index (LAI)}

Summary statistics for LAI of each vegetation association are given in Fig. 4.8. Because the data were not normally distributed, non-parametric techniques were used to analyse the differences between sets of measurements. For each delta region, LAI distributions at each vegetation association were compared using the Kruskall-Wallis test. For all three delta regions, results yielded test statistics with an associated p-value of $<$ 0.05 . This indicates that the LAI distribution at one vegetation association at least, was statistically different from the others. The pairs of vegetation associations which differed from one another were confirmed using the Bonferroni correction (Table 4.4).

There were no significant differences in LAI between Horsetail and Willowhorsetail communities. Given that Horsetail communities were dominated by herbaceous vegetation while Willow-horsetail communities were dominated by tall willow shrubs, these results may appear surprising. 


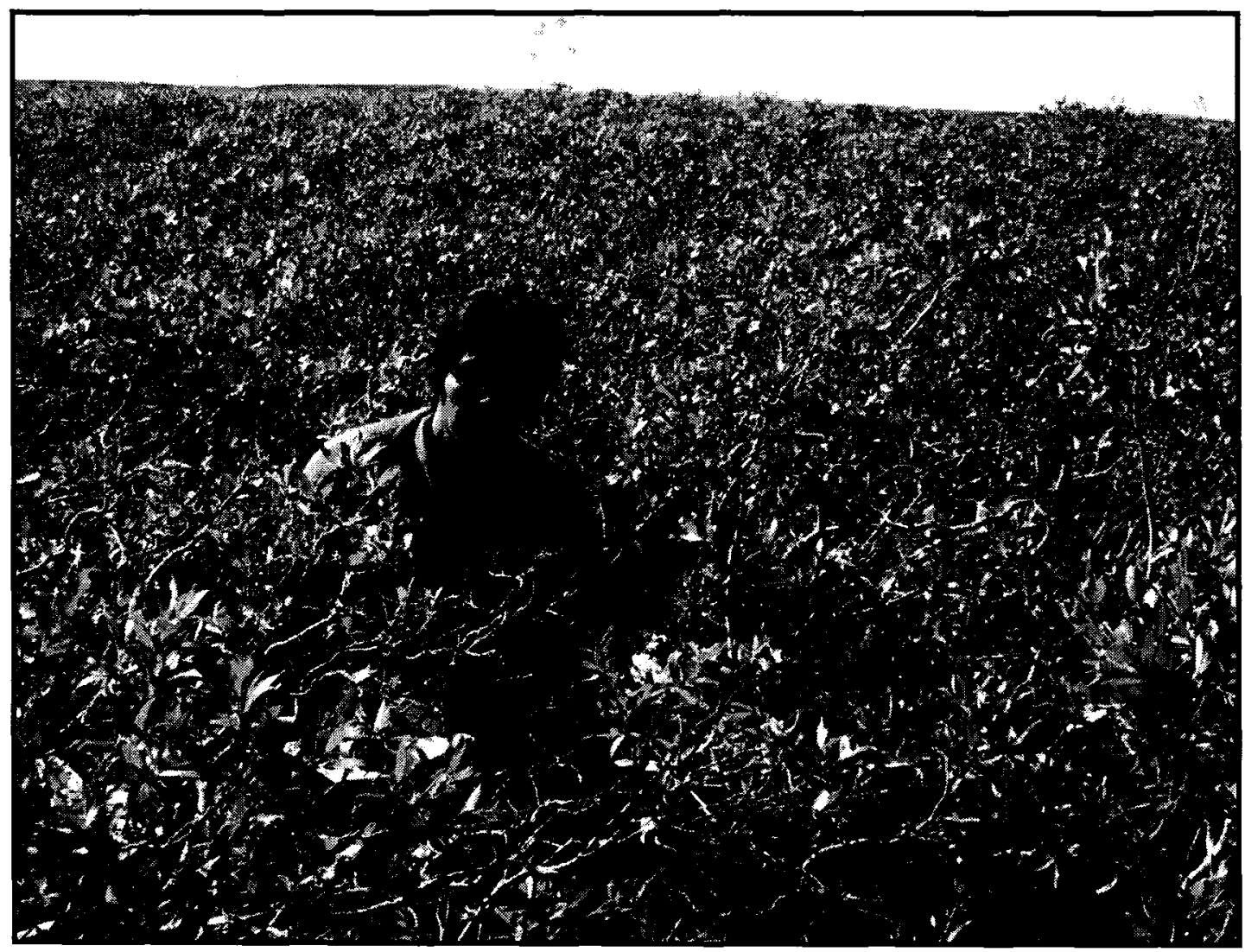

Fig. 4.7 - Short-willow community in the northern delta at site ND48 (August 3, 2006).

Willow shrubs were stunted at 0.5-1.2 $\mathrm{m}$ tall with intertwining branches creating a dense cover. 

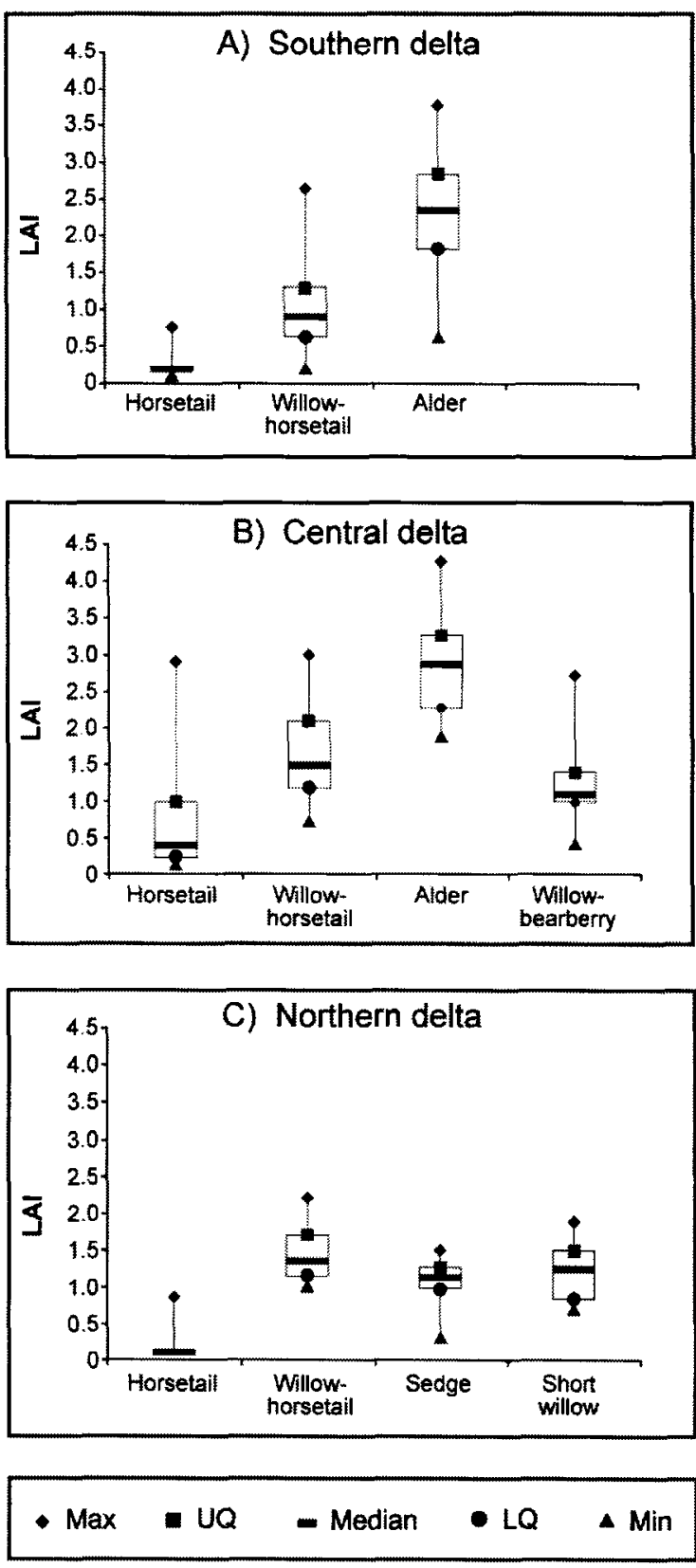

Fig. 4.8 - Box-and-whisker plots for LAI measured at different vegetation associations. The edges of the boxes are the upper and lower quartiles of the distribution, while the medians are indicated by the middle horizontal line. No meaningful quartile values are given for Horsetail associations, since only 8 plots were sampled in the southern delta and 8 in the northern delta. 
Factors that could explain these results include: (1) upper parts of the Horsetail communities, closer to the transition into Willow-horsetail communities, were sampled; (2) small sample size for Horsetail communities; and (3) human bias could have occurred since LAI measurements were taken by different people in the field party.

In the central delta, the greatest difference found between Willow-horsetail and Willow-bearberry communities was in the ground cover with Willow-bearberry communities having greater plant richness. Since LAI is related to canopy density, the fact that willows were slightly shorter at Willow-bearberry sites may not have been a significant differentiating factor between the two willow-dominated communities.

In the northern delta, there were no significant differences in LAI between Willow-horsetail and Short willow communities. This is analogous to the case of Willow-horsetail vs. Willow-bearberry communities in the central delta. Although shrubs in Short willow communities were much shorter, vegetation density was similar to the one in Willow-horsetail zones.

In summary, analyses of variance of LAI showed that Alder communities were distinct from all other vegetation associations in the southern and central delta. In the northern delta, significant differences in LAI distribution were found between Horsetail and Willow-horsetail communities as well as between Horsetail and Short willow communities. Results of pairwise comparison between the other vegetation communities indicated that it may be difficult to differentiate them based on LAI since there were no significant differences found at the 0.05 level. This may affect spectral vegetation indices, resulting in lack of differentiation of these communities in the SPOT images. 
Table 4.4 - Summary of pairwise comparisons of LAI between vegetation associations.

The p-values from the Bonferroni correction are presented below the diagonal.

Significant differences at a pairwise comparison level of 0.05 are presented in boldface.

\begin{tabular}{|c|c|c|c|c|}
\hline & \multicolumn{4}{|c|}{ Southern delta } \\
\hline & Horsetail & \multicolumn{2}{|c|}{ Willow-horsetail } & Alder \\
\hline Horsetail & $\mathrm{x}$ & & \\
\hline Willow-horsetail & 0.80 & \multicolumn{2}{|c|}{$\mathbf{x}$} & \\
\hline Alder & 0.01 & \multicolumn{2}{|c|}{$<0.01$} & $x$ \\
\hline & \multicolumn{4}{|c|}{ Central delta } \\
\hline & Horsetail & Willow-horsetail & Alder & Willow-bearberry \\
\hline Horsetail & $\mathrm{x}$ & & & \\
\hline Willow-horsetail & 0.17 & $\mathrm{x}$ & & \\
\hline Alder & $<0.01$ & 0.01 & $\mathrm{x}$ & \\
\hline \multirow[t]{3}{*}{ Willow-bearberry } & 1.00 & 1.00 & 0.01 & $x$ \\
\hline & \multicolumn{4}{|c|}{ Northern delta } \\
\hline & Horsetail & Willow-horsetail & Sedge & Short willow \\
\hline Horsetail & $\mathrm{x}$ & & & \\
\hline Willow-horsetail & $<0.01$ & $\mathrm{x}$ & & \\
\hline Sedge & 0.12 & 0.17 & $\mathrm{x}$ & \\
\hline Short willow & $<0.01$ & 1.00 & 1.00 & $\mathrm{x}$ \\
\hline
\end{tabular}




\subsection{Relation between vegetation and presence of near-surface permafrost}

In all three delta regions, there was a clear association between presence of permafrost in the upper $3 \mathrm{~m}$ and different vegetation communities (Tables 4.5-4.7). In the southern delta, $100 \%$ of the Horsetail and the Willow-horsetail communities were associated with absence of near-surface permafrost. In contrast, $96 \%$ of Alder plots were related to presence of near-surface permafrost. The only site where near-surface permafrost was not found in an Alder plot was SD6, located on an alluvial island in Middle Channel. The absence of near-surface permafrost at SD6 appeared to be corroborated by Pearce (1994). Permafrost was only found in spruce sites on the highest elevations of alluvial islands (Pearce 1994). However, Pearce (1994) used a 1.2-m metal probe to measure active-layer thickness and, therefore the thickness investigated was much shallower than the one used in this research.

In the central delta, $91 \%$ of Horsetail communities and $90 \%$ of Willow-horsetail communities were characterized by absence of near-surface permafrost. On the other hand, $100 \%$ of Alder and Willow-bearberry communities were related to presence of near-surface permafrost. Permafrost was found in Willow-horsetail communities at sites CD20 and CD25, and in the Horsetail community at site CD25. Compared to other sites in the central delta, these sites appeared to be higher in elevation although levelling was not carried out during this research due to time constraints. The higher elevation may indicate that the river channel at these sites was more stable and, therefore the thermal recovery may be at a more advanced stage there. 
Table 4.5 - Relation between vegetation associations and presence of near-surface permafrost in the southern delta.

\begin{tabular}{|c|c|c|c|c|}
\hline \multirow{2}{*}{\multicolumn{2}{|c|}{ Vegetation association }} & \multicolumn{2}{|c|}{ Permafrost } & \multirow[b]{2}{*}{ Total } \\
\hline & & Absent & Present & \\
\hline \multirow[t]{2}{*}{ Alder } & Count of plot & 1 & 24 & 25 \\
\hline & Within association & $4.0 \%$ & $96.0 \%$ & $100 \%$ \\
\hline \multirow[t]{2}{*}{ Horsetail } & Count of plot & 8 & 0 & 8 \\
\hline & Within association & $100 \%$ & $0 \%$ & $100 \%$ \\
\hline \multirow[t]{2}{*}{ Willow-horsetail } & Count of plot & 19 & 0 & 19 \\
\hline & Within association & $100 \%$ & $0 \%$ & $100 \%$ \\
\hline \multirow[t]{2}{*}{ Total } & Count of plot & 28 & 24 & 52 \\
\hline & Within association & $53.8 \%$ & $46.2 \%$ & $100 \%$ \\
\hline
\end{tabular}

Table 4.6 - Relation between vegetation associations and presence of near-surface permafrost in the central delta.

\begin{tabular}{|l|l|r|r|r|}
\hline \multirow{2}{*}{ Vegetation association } & \multicolumn{2}{|c|}{ Permafrost } & \multirow{2}{*}{ Total } \\
\cline { 3 - 4 } & Count of plot & 0 & 18 & 18 \\
\cline { 2 - 5 } & Within association & $0 \%$ & $100 \%$ & $100 \%$ \\
\hline \multirow{2}{*}{ Horsetail } & Count of plot & 10 & 1 & 11 \\
\cline { 2 - 5 } & Within association & $90.9 \%$ & $9.1 \%$ & $100 \%$ \\
\hline \multirow{2}{*}{ Willow-bearberry } & Count of plot & 0 & 8 & 8 \\
\cline { 2 - 5 } & Within association & $0 \%$ & $100 \%$ & $100 \%$ \\
\hline \multirow{2}{*}{ Willow-horsetail } & Count of plot & 18 & 2 & 20 \\
\cline { 2 - 5 } & Within association & $90.0 \%$ & $10.0 \%$ & $100 \%$ \\
\hline \multirow{2}{*}{ Total } & Count of plot & 28 & 29 & 57 \\
\cline { 2 - 5 } & Within association & $49.1 \%$ & $50.9 \%$ & $100 \%$ \\
\hline
\end{tabular}


Table 4.7 - Relation between vegetation associations and presence of near-surface permafrost in the northern delta.

\begin{tabular}{|c|c|c|c|c|}
\hline \multirow{2}{*}{\multicolumn{2}{|c|}{ Vegetation association }} & \multicolumn{2}{|c|}{ Permafrost } & \multirow[b]{2}{*}{ Total } \\
\hline & & Absent & Present & \\
\hline \multirow[t]{2}{*}{ Horsetail } & Count of plot & 0 & 8 & 8 \\
\hline & Within association & $0 \%$ & $100 \%$ & $100 \%$ \\
\hline \multirow[t]{2}{*}{ Sedge } & Count of plot & 0 & 10 & 10 \\
\hline & Within association & $0 \%$ & $100 \%$ & $100 \%$ \\
\hline \multirow[t]{2}{*}{ Short willow } & Count of plot & 0 & 15 & 15 \\
\hline & Within association & $0 \%$ & $100 \%$ & $100 \%$ \\
\hline \multirow[t]{2}{*}{ Willow-horsetail } & Count of plot & 10 & 2 & 12 \\
\hline & Within association & $83.3 \%$ & $16.7 \%$ & $100 \%$ \\
\hline \multirow[t]{2}{*}{ Total } & Count of plot & 10 & 35 & 45 \\
\hline & Within association & $22.2 \%$ & $77.8 \%$ & $100 \%$ \\
\hline
\end{tabular}


In the northern delta, the obvious difference setting this region apart from the other two delta regions was the presence of near-surface permafrost at all plots in Horsetail communities. All Sedge and Short willows sampling plots were associated with near-surface permafrost. In contrast, $83 \%$ of Willow-horsetail plots had no near-surface permafrost. Permafrost was detected in Willow-horsetail zones at two sites, ND36 and ND41. The particularity of the Willow-horsetail zone at these two sites was its short width. While the average width of Willow-horsetail zones in the northern delta was $40 \mathrm{~m}$, the widths at ND36 and ND41 were shortest at $21 \mathrm{~m}$ and $23 \mathrm{~m}$ respectively.

From the perspective of variability within a vegetation community, there were 15 plots throughout the three delta regions where the three drilled holes had more than one value of presence or absence. Nine of these sampling plots were in Willow-horsetail communities, five in were in Alder zones and one was a Horsetail community. Table 4.8 shows the relation between vegetation associations and presence of near-surface permafrost when drilled holes are grouped by vegetation zone and by delta region.

In summary, Horsetail communities in the southern and central delta as well as Willow-horsetail communities in all three delta regions were not associated with nearsurface permafrost. Permafrost was present beneath all other vegetation associations.

\subsection{Concluding remarks}

Assessments of shoreline variations indicated that the instantaneous shoreline captured by SPOT-5 in July may be used in this research to represent average conditions in the Delta. Shoreline variations from June to August averaged about $10 \mathrm{~m}$. The composition and structure of vegetation was distinct between the various associations at 
Table 4.8 - Relation between presence of near-surface permafrost and vegetation association with drilled holes grouped by vegetation association and by delta region.

\begin{tabular}{|c|c|c|}
\hline \multirow{2}{*}{ Vegetation association } & \multicolumn{2}{|c|}{ Near-surface permafrost } \\
\cline { 2 - 3 } Southern delta & Present (\% of drilled holes) & Absent (\% of drilled holes) \\
\cline { 2 - 3 } & & \\
Horsetail $(\mathrm{n}=24)$ & 0 & 100 \\
Willow-horsetail $(\mathrm{n}=57)$ & 2 & 98 \\
Alder $(\mathrm{n}=75)$ & 89 & 11 \\
& & \\
Central delta & & \\
& & 95 \\
Horsetail $(\mathrm{n}=33)$ & 5 & 91 \\
Willow-horsetail $(\mathrm{n}=60)$ & 9 & 2 \\
Alder $(\mathrm{n}=54)$ & 98 & 0 \\
Willow-bearberry $(\mathrm{n}=24)$ & 100 & \\
& & \\
Northern delta & & 0 \\
& 100 & 0 \\
Horsetail $(\mathrm{n}=24)$ & 100 & 0 \\
Sedge $(\mathrm{n}=30)$ & 25 & 0 \\
Willow-horsetail $(\mathrm{n}=36)$ & 100 & \\
Short willow $(\mathrm{n}=45)$ & &
\end{tabular}


each study site. Horsetail communities in the southern and central delta as well as Willow-horsetail communities in all three delta regions were associated with absence of permafrost in the upper $3 \mathrm{~m}$. Permafrost was present beneath all other vegetation associations.

Analyses of variance of LAI showed that with the exception of Alder communities in the southern and central delta, and Horsetail vs. Willow-horsetail and Horsetail vs. Short willow communities in the northern delta, it is difficult to differentiate the vegetation associations based on this canopy cover variable alone. 


\section{CHAPTER FIVE}

\section{IMAGE DATA ANALYSIS METHODS}

\subsection{Introduction}

Field data analyses demonstrated that the spatial distribution of vegetation associations can be used to predict near-surface permafrost presence in the Mackenzie Delta. Therefore, it was hypothesized that remote sensing techniques can be applied to extrapolate field surveys. This chapter describes various image data analysis methods used to map vegetation communities in the Delta. The image data analysis steps are summarized in Fig. 5.1.

\section{2 $\quad$ SPOT-5 data acquisition}

SPOT-5 provides an ideal balance between high spatial resolution and wide-area coverage. Four cloud and haze-free SPOT-5 scenes, comprised of 4 Pan and 4 MS images, were acquired (Fig. 5.2). The images have a swath width of $60 \times 60 \mathrm{~km}$. The scene covering the northern delta was acquired on July 8,2006 . The central delta was covered by one scene in the western section and another in the eastern section. These scenes were acquired on July 25, 2006 and on July 14, 2006 for the western and eastern central delta, respectively. The southern delta scene was obtained on July 25, 2006.

\subsection{Images georeferencing}

The images were acquired from Iunctus Geomatics Inc. of Lethbridge, Alberta, with the pre-processing level $2 \mathrm{~A}$, which included a radiometric correction for variations due to detector sensitivity and a standard geometric correction to compensate for 


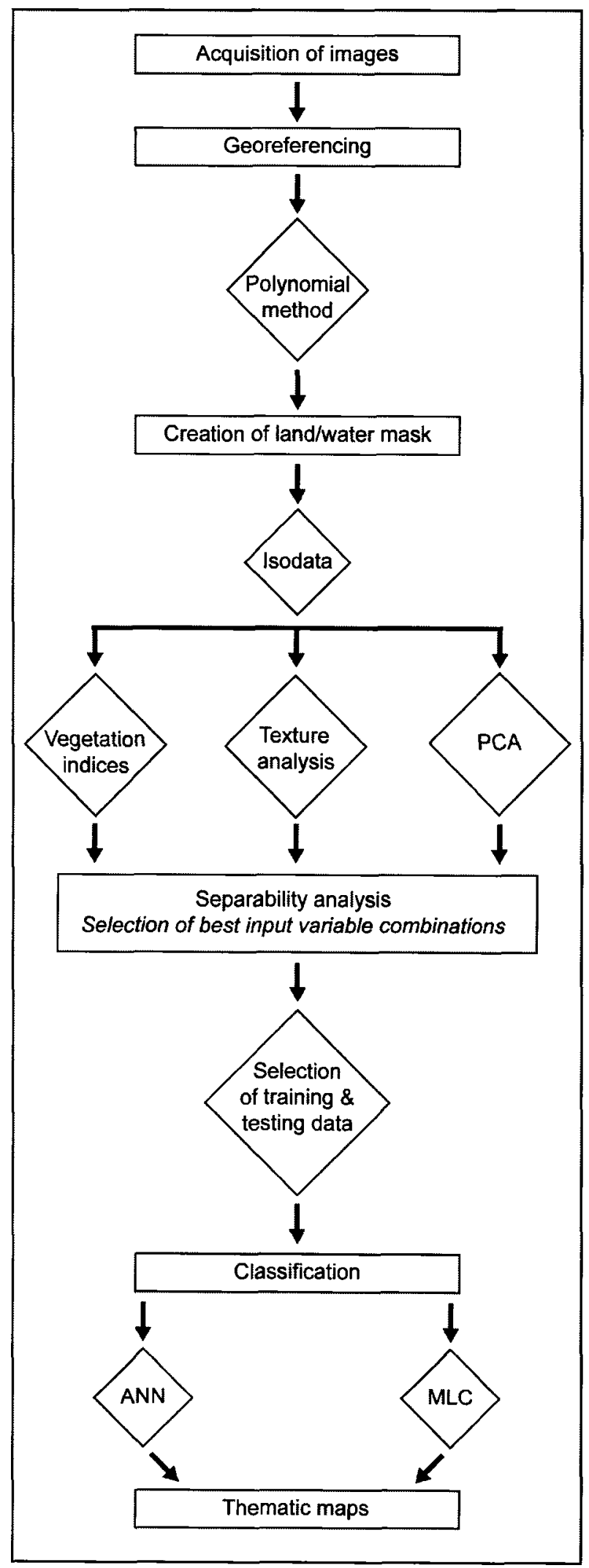

Fig. 5.1 - Image data analysis steps. 


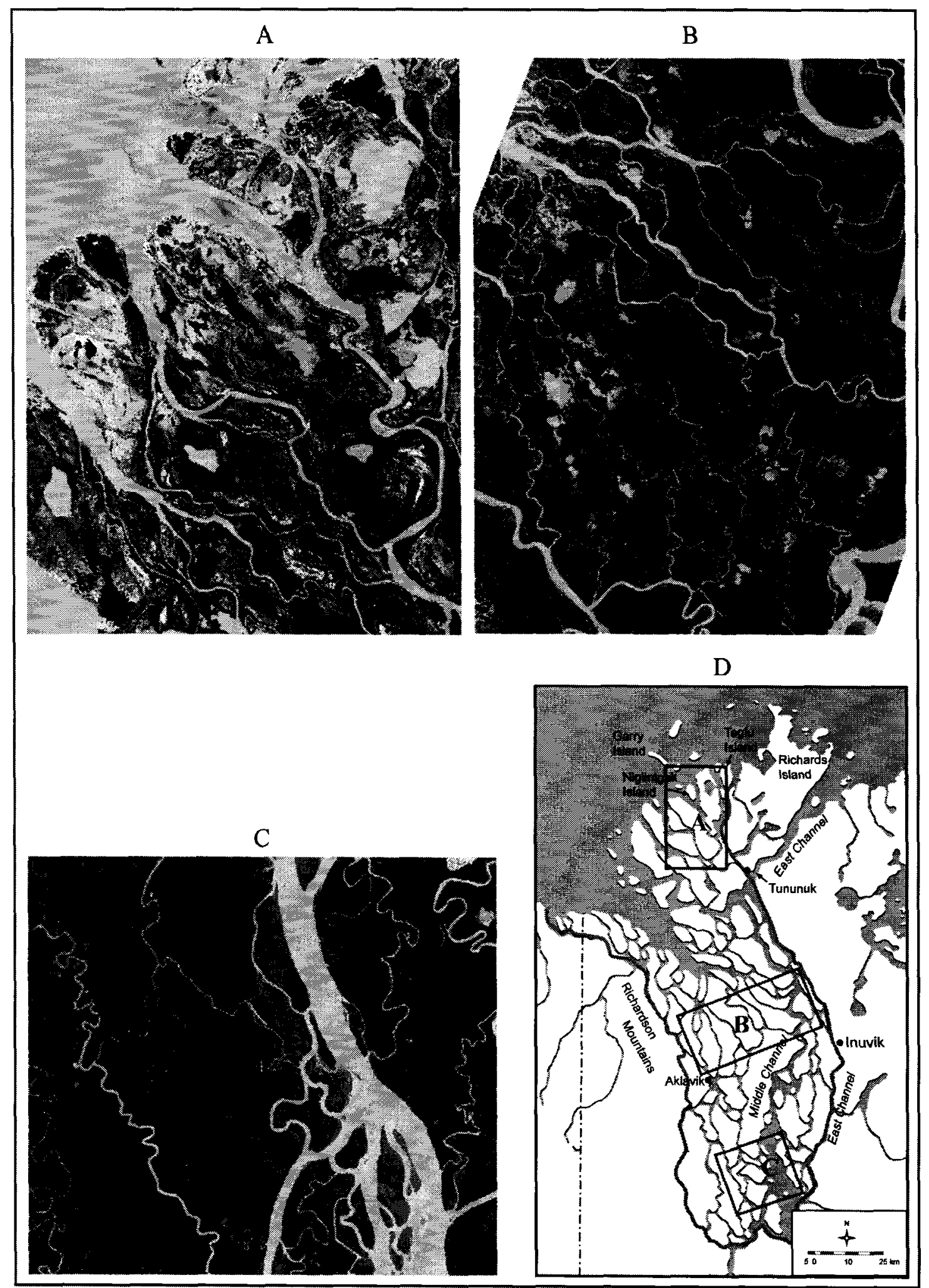

Fig. 5.2 - SPOT-5 MS images of the study areas: a) northern delta, b) central delta mosaic, c) southern delta, and d) image coverage of the Delta. 
systematic effects, including the Earth's rotation and curvature, and variations in the satellite's orbital altitude. The scenes were also rectified to match the standard map projection UTM WGS84 (zone 8 NAD 83).

Using PCI Geomatica software, the Pan images were georeferenced more accurately with six ground control points per image. A first order polynomial transformation and nearest neighbour resampling were used to georeference the images. The MS images were then aligned to the corrected Pan images (Pasher et al. 2007). Georeferencing was achieved with Root mean square (RMS) errors of [0.68 (x), 0.29 (y)] and $[0.19(\mathrm{x}), 0.11(\mathrm{y})]$ pixels for the Pan and MS images, respectively, of the southern delta. RMS errors of $[0.34(\mathrm{x}), 0.67(\mathrm{y})]$ and $[0.16(\mathrm{x}), 0.48(\mathrm{y})]$ pixels were obtained for the Pan and MS images, respectively, of the northern delta.

Image data for the central delta were delivered in two overlapping sections. Georeferencing was achieved with RMS errors of $[0.47(\mathrm{x}), 0.23(\mathrm{y})]$ and $[0.10(\mathrm{x}), 0.18$ (y)] pixels for the Pan and MS images, respectively, of the western section. RMS errors of $[0.52(\mathrm{x}), 0.15(\mathrm{y})]$ and $[0.15(\mathrm{x}), 0.12(\mathrm{y})]$ pixels were obtained for the Pan and MS images, respectively, of the eastern section. A mosaic was created from both the Pan and MS sections. To achieve a visually pleasing mosaic by evening out the maximum and minimum effects in tone, the normalization was set to "Across Image 3rd Order". This normalization corrects gradual bright and dark patterns from one side of the image to the other. Cutlines, used to crop the images so the best portions of the images are seamlessly joined together, were generated using the "Edge features" option. This option places cutlines in areas where there is the least amount of difference in grey and gradient values between the images. 
For all images, water was masked out using Isodata clustering with all the spectral bands as input and generating the PCI Geomatica default value of 16 clusters. These clusters were then manually aggregated to produce a land/water binary mask with the help of aerial photographs and vegetation field data. No accuracy assessment was conducted on this classification since water was not sampled in the field.

\subsection{Determination of the extent of alluvial islands in the southern delta}

Pearce (1986) has already established through aerial photograph studies that point bars occupied about $18 \%$ of the land surface in the Delta. No mention was made whether this value was consistent throughout the three delta regions. Therefore, in this research, point bars were assumed to represent $18 \%$ of the land surface in all three delta regions. However, the extent of alluvial islands in the southern delta was not known. At such sites, near-surface permafrost in Willow-horsetail and Alder communities was determined in the field to be absent. In order to estimate this extent, these islands were clipped from the southern delta image and their proportion of the total land surface was calculated.

\subsection{Image data transformations}

\subsubsection{Atmospheric correction}

No atmospheric correction was carried out given that the single date images were analysed separately and training data were derived from the images to be classified (Song et al. 2001). Since the images were haze-free, atmospheric effects that could contaminate different vegetation indices were considered as comparable across the images. 


\subsubsection{Principal Component Analysis (PCA)}

Table 5.1 shows the inter-band correlations for the spectral data of the three images, with high correlations $(r>0.8)$ between the Red and Green bands. PCAs were conducted using all the spectral bands to provide orthogonal variables as input to classifiers (Dillabaugh and King 2005; Lu and Weng 2007).

\subsubsection{Texture analysis}

Six texture measures Homogeneity (HOM), Contrast (CON), Dissimilarity (DIS), Entropy (ENT), Angular Second Moment (A2M), and Correlation (COR) were extracted from the Green, NIR, and SWIR bands using a window size of $3 \times 3$ for MS images and two window sizes, $3 \times 3$ and $5 \times 5$, for Pan images. These bands were selected due to their low inter-band correlation $(r<0.8)$. The maximum window sizes of $3 \times 3$ and $5 \times 5$ for the MS and Pan images, respectively, were selected because larger windows may overlap different vegetation types and introduce invalid spatial information. Default values of inter-pixel angle (direction invariant), inter-pixel distance (adjacent pixels), and quantization (32 bits) were used.

Since the analysis of the correlation matrix among all the texture measures with different window sizes showed high correlations $(r>0.8)$, PCA was applied to the $18 \mathrm{MS}$ and 12 Pan texture measures of each image separately. This operation resulted in the production of MS texture components (PC_TEX_MS) and Pan texture components (PC_TEX_Pan). These components were used to verify the added value of texture analysis in image classifications. 
Table 5.1 - Correlation matrix showing $\mathrm{r}$ values for SPOT-5 spectral bands. High correlations are in bold $(r>0.8)$ following the criteria proposed by Wulder (2005).

\begin{tabular}{|c|c|c|c|c|}
\hline Southern delta & NIR & Red & Green & SWIR \\
\hline NIR & 1.00 & & & \\
\hline Red & -0.12 & 1.00 & & \\
\hline Green & 0.13 & 0.95 & 1.00 & \\
\hline SWIR & 0.62 & 0.34 & 0.50 & 1.00 \\
\hline Central delta & NIR & Red & Green & SWIR \\
\hline NIR & 1.00 & & & \\
\hline Red & -0.29 & 1.00 & & \\
\hline Green & 0.07 & 0.87 & 1.00 & \\
\hline SWIR & 0.59 & 0.12 & 0.31 & 1.00 \\
\hline Northern delta & NIR & Red & Green & SWIR \\
\hline NIR & 1.00 & & & \\
\hline Red & -0.44 & 1.00 & & \\
\hline Green & -0.26 & 0.93 & 1.00 & \\
\hline SWIR & 0.51 & 0.33 & 0.36 & 1.00 \\
\hline
\end{tabular}




\subsubsection{Vegetation indices (VI)}

Vegetation indices deemed to be most relevant to tundra vegetation communities and riparian vegetation mapping were derived and included: NDVI, SAVI, and MSAVI. The soil-adjusted indices were selected because they may help in differentiating vegetation communities with low canopy cover from denser associations. Bare ground and non-photosynthetic litter that could affect the green vegetation reflectance signal would be visible from above in low-canopy cover vegetation communities.

Since field results indicated that LAI could not be used decisively to differentiate vegetation communities in the Mackenzie Delta, LAI mapping with VIs was not performed in order to classify vegetation associations.

\subsection{Vegetation communities' classification}

\subsubsection{Selection of training and testing data}

Training and testing data were generated for the $2 \times 2$ pixel window at each location where vegetation sampling and near-permafrost probing were carried out in the field. Training and testing data $(60 \% / 40 \%)$ were chosen randomly among field sampled plots while trying to ensure a minimum of 40 training pixels for each class. For vegetation associations with too few sampled plots, additional training and testing data were created by appending the four adjacent pixels of existing plots in the direction parallel to channels. To avoid possible bias in the selection of training data, two different combinations of training sites were tested for each image.

Although single-pixel training may be implemented to avoid spatial autocorrelation effects, it does not always lead to more accurate classification results than 
other training approaches involving contiguous pixel selection (Chen and Stow 2002). Small-block training has the benefit of capturing spectral and spatial information, especially for spatially heterogeneous classes. Chen and Stow (2002) also found that using texture measures tended to reduce the differences of classification results caused by training strategies. For testing data, the pixels within each $2 \times 2$ pixels sampling site were also autocorrelated. However, it was not possible to sample enough individual pixel locations to develop a validation dataset of low spatial autocorrelation.

\subsubsection{Separability analysis}

Separability analyses (SA) were carried out using the Bhattacharrya Distance (BD), a distance measure that accounts for class variance-covariance in calculating the statistical separation between pairs of sample training data (Jensen 1996). BD is scaled to a range of 0 to 2 , where 0 corresponds to complete overlap between training data distributions and 2 represents complete separation between classes (PCI Geomatica 2005). SAs were conducted in order to determine the possible aggregations of vegetation classes and the combinations of input variables having the best potential to differentiate vegetation communities.

In order to find out the appropriate number of texture components to use, SAs were carried out with all spectral bands and different combinations of PC_TEX_MS and PC_TEX_Pan. The texture combinations that increased the minimum and average BD the most were retained for further analysis. SAs were also conducted with different VIs to determine the VI that would best enhance the separability between training data of various vegetation communities. The goal was to determine the best input variables 
combinations that included variables not highly correlated with each other $(r<0.8)$. These combinations were used as input to different classification tests.

\subsubsection{Maximum Likelihood Classification}

Maximum Likelihood Classifications (MLC) were conducted using probability density function bounds of three standard deviations for the training data distributions and equal a priori probabilities for all vegetation classes. Bounds of three standard deviations were used because each training site had been field validated and each training sample was selected in homogeneous areas of a vegetation class. Equal a priori probabilities were used since it was not possible to determine beforehand the class spatial proportions so they were assumed to be equally likely to occur at any location.

\subsubsection{Neural Network Classifications}

Neural network classifications were conducted to compare achieved accuracy levels with MLCs. Feed forward back-propagating ANNs were used to classify the various vegetation communities. First, eight network configurations with different numbers of iterations as well as momentum and learning rates were tested with the two best input variable combinations used in MLC for each image. Momentum and learning rate combinations of $0.9-0.1$ and $0.6-0.2$ were used with 1000 and 100000 iterations. If error levels still exceeded the acceptable limit for individual (0.001) and total (0.01) error then the number of iterations was increased to 250000 for the ANN with the lowest error levels. Training and testing data used for MLCs were also drawn on for the ANNs tested. 


\subsubsection{Linear Spectral Unmixing}

A constrained least squares linear spectral unmixing algorithm, implemented as UNMIX in PCI Geomatica, was used to extract sub-pixel vegetation information. The constraints specified that the unmixed fractions must be positive, and the sum of the fractions for all endmembers must equal one. The least squares method works by iteratively minimizing the sum of squares of the errors, based on the training pixels (PCI Geomatica 2005). Manual selection of endmembers was performed using training data already utilized in MLCs and ANNs. It was assumed that these endmembers were spectrally pure while accounting for all the sub-pixel fraction components that would be present in the images.

Many studies using spectral unmixing do not actually focus on unmixing land cover types but rather radiometric scene components such as green photosynthetic vegetation, soil, and shadow (e.g. Lévesque and King 2003; Pasher and King 2007). When determined in this manner, the endmembers sometimes do not represent a single meaningful cover type. In this study, endmembers were selected as single, meaningful vegetation types. This endmember selection technique was used successfully to map five land cover fractions that include bare soil, grass, deciduous shrub, conifer, and water along an $1100 \mathrm{~km}$ north-south transect crossing the tree line of northern Canada (Olthof and Fraser 2007).

Since no vegetation sampling was performed in vegetation transition zones due to time constraints, it was not possible to validate the results of spectral unmixing. However, the fraction images were useful in assessing the purity of training data used as endmembers as well as the vegetation gradation from one community to another. In order 
to test the usefulness of spectral unmixing, the southern delta image was used, and results were plotted along the SD3 transect to show proportions of endmembers at training sites as well as at $2 \times 2$ windows in transition zones between these training sites. 


\section{CHAPTER SIX}

\section{IMAGE DATA ANALYSIS RESULTS AND ESTIMATION OF NEAR-SURFACE PERMAFROST EXTENT}

\subsection{Introduction}

This chapter discusses results of image data analyses carried out following the methods described in Chapter 5. From those tested, the most appropriate classification techniques for mapping vegetation communities in the Mackenzie Delta are determined. The accuracies of the resulting maps are also evaluated and estimates of the extent of near-surface permafrost in the Delta are provided.

\subsection{Principal Component Analyses (PCA)}

PCA conducted using the four spectral bands for the three MS images showed that the first three PCs accounted for over $99 \%$ of the total variance in the data (Table 6.1a). In the southern delta, $\mathrm{PCl}$ was highly positively correlated with the Green band and had an inverse relation to the Red band (Table 6.1b). This may indicate that PC1 represents a vegetation gradient (Fig. 6.1c). PC2 was highly positively correlated with the NIR and the SWIR band. Shrubby deciduous vegetation areas had the highest brightness while spruce forests were darker. Therefore, PC2 may be interpreted as a deciduous component. PC3 was also highly positively correlated with the NIR band, but only accounted for a small percentage of data variance. Visually, only areas closest to shorelines were bright. Other vegetation zones had a mixture of grey tones.

In the central delta, $\mathrm{PCl}$ can be labelled as the "greenness" component since it had an almost perfect positive relation with the NIR band, in which vegetation reflectance 
Table 6.1 - PCA of spectral data: a) Percentage of total variance in the data associated with each principal component, and b) Factor loadings shown as $r$ values. High correlations $(r>0.8)$ are presented in boldface.

a)

\begin{tabular}{|c|c|}
\hline Southern delta & \% variance \\
\hline PC1 & 80.7 \\
\hline PC2 & 17.6 \\
\hline PC3 & 1.6 \\
\hline PC4 & 0.1 \\
\hline \multicolumn{2}{|c|}{} \\
\hline Central delta & \% variance \\
\hline PC1 & 83.4 \\
\hline PC2 & 12.5 \\
\hline PC3 & 4.0 \\
\hline PC4 & 0.1 \\
\hline \multicolumn{2}{|c|}{} \\
\hline Northern delta & \% variance \\
\hline PC1 & 49.7 \\
\hline PC2 & 46.5 \\
\hline PC3 & 3.6 \\
\hline PC4 & 0.2 \\
\hline
\end{tabular}

b)

\begin{tabular}{|c|c|c|c|c|}
\hline Southern delta & PC1 & PC2 & PC3 & PC4 \\
\hline NIR & 0.29 & $\mathbf{0 . 7 5}$ & $\mathbf{0 . 8 1}$ & -0.68 \\
\hline Red & $\mathbf{- 0 . 9 1}$ & -0.12 & -0.52 & 0.10 \\
\hline Green & $\mathbf{0 . 9 8}$ & 0.18 & -0.31 & -0.20 \\
\hline SWIR & 0.53 & $\mathbf{0 . 7 9}$ & 0.05 & -0.40 \\
\hline \multicolumn{5}{|l}{} \\
\hline Central delta & $\mathbf{P C 1}$ & $\mathbf{P C 2}$ & $\mathbf{P C 3}$ & PC4 \\
\hline NIR & $\mathbf{0 . 9 9}$ & -0.12 & 0.03 & -0.01 \\
\hline Red & -0.25 & 0.58 & $\mathbf{0 . 7 7}$ & -0.13 \\
\hline Green & 0.11 & 0.51 & $\mathbf{0 . 8 3}$ & 0.21 \\
\hline SWIR & 0.69 & 0.71 & -0.15 & 0.01 \\
\hline \multicolumn{7}{|l|}{} & & & PC4 \\
\hline Northern delta & $\mathbf{P C 1}$ & $\mathbf{P C 2}$ & $\mathbf{P C 3}$ & $\mathbf{0 . 8 8}$ \\
\hline NIR & $\mathbf{0 . 7 8}$ & -0.01 & $\mathbf{- 0 . 9 1}$ & -0.68 \\
\hline Red & 0.03 & $\mathbf{- 0 . 8 9}$ & 0.73 & -0.41 \\
\hline Green & 0.13 & $\mathbf{- 0 . 9 4}$ & -0.56 & 0.12 \\
\hline SWIR & $\mathbf{0 . 9 1}$ & -0.54 & -0.11 & \\
\hline
\end{tabular}




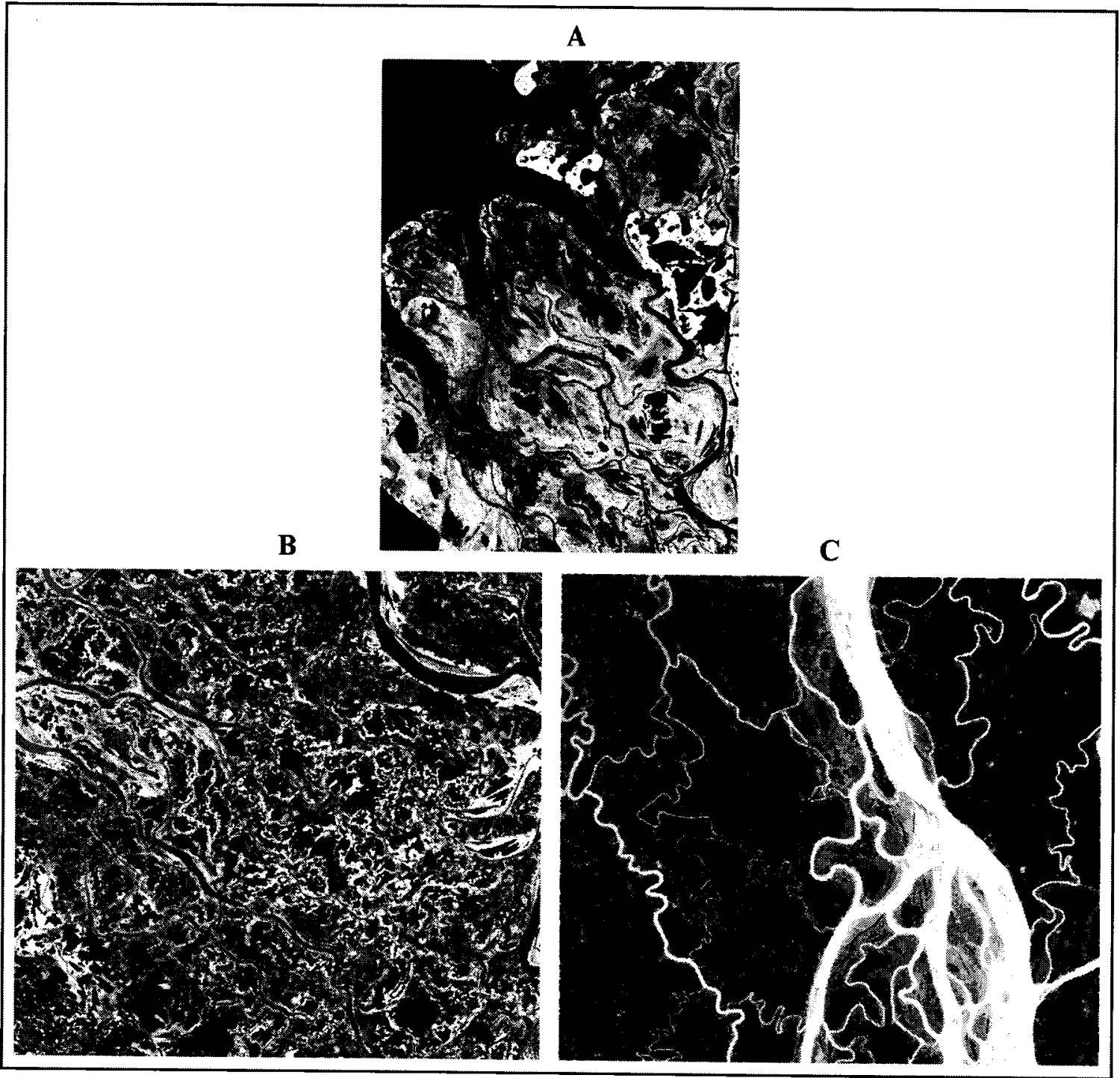

Fig. 6.1 - Principal Component Analysis: a) northern delta's PC1, b) central delta's PC2, and c) southern delta's PC1. 
is high. PC2 had the highest correlation with the SWIR band and, as in the southern delta; shrubby deciduous vegetation had the highest brightness (Fig. 6.1b). PC2 could also be considered as a moisture gradient since water appeared dark compared to land surfaces. PC3, accounting for only $4 \%$ of the variance, showed a strong positive relation to the green band and may be loosely considered a vegetation gradient, since all areas of the image showed a mixture of grey tones.

In the northern delta, PC1 was highly positively correlated with the SWIR and NIR bands. The reflectance of vegetation in the SWIR region is varied, depending on the types of plant and their water contents. Reflectance of leaves in SWIR generally increases as the water content decreases, so the SWIR band can be used to detect plant drought stress (Lillesand et al. 2004). Therefore, PC1 may be characterized as a leaf-watercontent component or a moisture gradient since water appeared dark (Fig. 6.1a). Visually, the brightest areas were in the northwestern section of Niglintgak Island and towards the western coastal regions. Although no sampling plots were established in those areas, this section of the northern delta was recently known to experience salinization resulting in the decay of short willows. PC2 had a high negative relation to the Red and Green as well as the SWIR bands and could be labelled as the wetness component. As PC2 values or wetness increased, these channels absorbed more of the energy. PC3 had a strong negative correlation to the NIR band. It could be characterized as a vegetation gradient since areas with darker tones indicated increased NIR reflectance. 


\subsection{Separability analyses}

\subsubsection{Initial class merging using spectral bands and components}

Separability analyses (SA) using spectral bands and components were carried out separately. In the southern delta, SAs indicated that the lowest Bhattacharrya Distances (BD) were obtained in the cases of Horsetail vs. Willow-horsetail and Alder vs. Willowhorsetail (Table 6.2). Since Alder communities and Willow-horsetail communities have different permafrost presence conditions, they could not be merged. However, since field results indicated that both Horsetail and Willow-horsetail associations were characterized by absence of near-surface permafrost and that there were no statistically significant differences in LAI between Horsetail and Willow-horsetail communities, it was decided to merge these two classes into a single Willow-horsetail class.

Separability between training samples in the central delta mosaic image was particularly low between Horsetail and Willow-horsetail classes (Table 6.3). As in the case of the southern delta, it was decided to merge these two classes. Alder and Willowbearberry classes were also merged in a single Alder class since the separability between them was also low and they were both underlain by near-surface permafrost.

In the northern delta, the lower average separability was probably due to the absence of trees and differentiating shrubby classes was more difficult (Table 6.4). LAI analyses already confirmed that Sedge communities were not found to be statistically different from any other vegetation associations. Since both Horsetail and Sedge associations were underlain by near-surface permafrost and are both herbaceous classes located closest to shorelines, they were merged into one Horsetail-sedge class. Willowhorsetail and Short willow classes could not be merged since they were characterized by 
Table 6.2 - Southern delta: Separability analyses using spectral bands and spectral components. BD is scaled to a range of $0-2$.

\begin{tabular}{|c|c|c|c|c|}
\hline & Horsetail & Alder & Spruce & Willow-horsetail \\
\hline Horsetail & $\mathrm{x}$ & & & \\
\hline Alder & 1.98 & $\mathrm{x}$ & & \\
\hline Spruce & 1.99 & 1.86 & $\mathrm{x}$ & \\
\hline Willow-horsetail & 1.58 & 1.14 & 1.97 & $\mathrm{x}$ \\
\hline
\end{tabular}

Table 6.3 - Central delta: Separability analyses using spectral bands and spectral components. $\mathrm{BD}$ is scaled to a range of $0-2$.

\begin{tabular}{|c|c|c|c|c|c|}
\hline & Horsetail & $\begin{array}{c}\text { Willow- } \\
\text { horsetail }\end{array}$ & Alder & $\begin{array}{c}\text { Willow- } \\
\text { bearberry }\end{array}$ & Spruce \\
\hline Horsetail & $\mathrm{x}$ & & & & \\
\hline $\begin{array}{c}\text { Willow- } \\
\text { horsetail }\end{array}$ & 0.88 & $\mathrm{x}$ & & & \\
\hline Alder & 1.79 & 1.16 & $\mathrm{x}$ & & \\
\hline $\begin{array}{c}\text { Willow- } \\
\text { bearberry }\end{array}$ & 1.84 & 1.47 & 1.45 & $\mathrm{x}$ & \\
\hline Spruce & 1.84 & 1.75 & 1.53 & 1.69 & $\mathrm{x}$ \\
\hline
\end{tabular}

Table 6.4 - Northern delta: Separability analyses using spectral bands and spectral components. BD is scaled to a range of $0-2$.

\begin{tabular}{|c|c|c|c|c|c|}
\hline & Horsetail & Sedge & $\begin{array}{c}\text { Willow- } \\
\text { horsetail }\end{array}$ & Short willow & $\begin{array}{c}\text { Bare } \\
\text { ground }\end{array}$ \\
\hline Horsetail & $\mathrm{x}$ & & & & \\
\hline Sedge & 0.65 & $\mathrm{x}$ & & & \\
\hline Willow-horsetail & 1.78 & 1.72 & $\mathrm{x}$ & & \\
\hline Short willow & 1.64 & 1.51 & 1.41 & $\mathrm{x}$ & \\
\hline Bare ground & 2.00 & 2.00 & 2.00 & 2.00 & $\mathrm{x}$ \\
\hline
\end{tabular}


different permafrost conditions. A bare ground class was also added to reflect the presence of bare ground near the coast as well as at the Camp Farewell airfield (Fig. 1.1).

\subsubsection{Determination of the best texture components}

Texture components (PC_TEX_MS and PC_TEX_Pan) were combined with all spectral bands in SAs. In total, there were 18 PC_TEX_MS and 12 PC_TEX_Pan for each image. Table 6.5 shows the SA results for the 3 highest ranked combinations for each image. This table also indicates that the inclusion of texture information increased the separability levels dramatically when compared to Tables 6.2-6.4. High ranking was given to combinations with the best minimum BD. Correlation matrices were analyzed and showed that there were low correlations between all PC_TEX_MS and PC_TEX_Pan $(\mathrm{r}<0.8)$. Texture component combinations that provided the highest separability between training data were retained for subsequent classifications.

\subsubsection{Determination of the best vegetation index}

Since the three vegetation indices were highly correlated, it was decided only to select one best index for classifications. Correlation levels between vegetation indices and spectral bands as well as between these indices and spectral components were also examined. For all three images, vegetation indices were highly correlated to the Red and NIR bands. Spectral bands and components with low correlation levels with vegetation indices were selected to be used in combination with the best texture combinations determined in section 6.3.2. Table 6.6 shows the variable combinations used in separability analyses to determine the best vegetation index. 
Table 6.5 - Highest ranking texture components combinations used with spectral bands in separability analyses. The best texture combinations are in boldface.

\begin{tabular}{|c|c|c|c|}
\hline Southern delta & $\begin{array}{c}\text { Minimum } \\
\text { separability }\end{array}$ & $\begin{array}{c}\text { Average } \\
\text { separability }\end{array}$ & $\%$ texture variance \\
\hline $\begin{array}{l}\mathrm{PC} 1-2-3 \text { TEX_MS + } \\
\mathrm{PC} 1-2-3 \text { TEX_Pan }\end{array}$ & 1.74 & 1.89 & $\begin{array}{l}81.7(\mathrm{MS}) \\
90.0(\mathrm{Pan}) \\
\end{array}$ \\
\hline $\begin{array}{l}\text { PC1-8_TEX_MS + } \\
\text { PC1-6_TEX_Pan }\end{array}$ & 1.81 & 1.89 & $\begin{array}{l}97.9(\mathrm{MS}) \\
98.4(\mathrm{Pan})\end{array}$ \\
\hline $\begin{array}{l}\text { PC1-8_TEX_MS + } \\
\text { PC1-2_TEX_Pan }\end{array}$ & 1.83 & 1.92 & $\begin{array}{l}97.9(\mathrm{MS}) \\
83.8(\mathrm{Pan})\end{array}$ \\
\hline Central delta & $\begin{array}{c}\text { Minimum } \\
\text { separability }\end{array}$ & $\begin{array}{c}\text { Average } \\
\text { separability }\end{array}$ & $\%$ texture variance \\
\hline $\begin{array}{l}\text { PC1-2-3_TEX_MS + } \\
\text { PC1-2-3 TEX_Pan }\end{array}$ & 1.79 & 1.86 & $\begin{array}{l}79.4(\mathrm{MS}) \\
95.5(\mathrm{Pan})\end{array}$ \\
\hline $\begin{array}{l}\text { PC1-9_TEX_MS + } \\
\text { PC1-5_TEX_Pan }\end{array}$ & 1.48 & 1.81 & $\begin{array}{l}98.5(\mathrm{MS}) \\
98.8(\mathrm{Pan})\end{array}$ \\
\hline $\begin{array}{l}\text { PC1-7_TEX_MS + } \\
\text { PC1-4_TEX_Pan } \\
\end{array}$ & 1.81 & 1.87 & $\begin{array}{l}95.7(\mathrm{MS}) \\
97.9(\mathrm{Pan})\end{array}$ \\
\hline Northern delta & $\begin{array}{l}\text { Minimum } \\
\text { separability }\end{array}$ & $\begin{array}{c}\text { Average } \\
\text { separability }\end{array}$ & $\%$ texture variance \\
\hline $\begin{array}{l}\text { PC1-2-3_TEX_MS + } \\
\text { PC1-2-3_TEX_Pan }\end{array}$ & 1.29 & 1.58 & $\begin{array}{l}86.0(\mathrm{MS}) \\
91.9(\mathrm{Pan}) \\
\end{array}$ \\
\hline $\begin{array}{l}\mathrm{PC} 1-7 \text { TEX_MS + } \\
\text { PC1-3_TEX_Pan }\end{array}$ & 1.71 & 1.83 & $\begin{array}{l}97.5(\mathrm{MS}) \\
91.9(\mathrm{Pan})\end{array}$ \\
\hline $\begin{array}{l}\text { PC1-7_TEX_MS + } \\
\text { PC1-5_TEX_Pan }\end{array}$ & 1.78 & 1.87 & $\begin{array}{l}97.5 \text { (MS) } \\
98.1 \text { (Pan) } \\
\end{array}$ \\
\hline
\end{tabular}


Table 6.6 - Variable combinations used in separability analyses to determine the most appropriate vegetation index. An additional combination with high separability is also presented for each image. PC_TEX refers to the best texture combinations determined from Table 6.5.

\begin{tabular}{|c|c|c|c|}
\hline Southern delta & $\begin{array}{c}\text { Minimum } \\
\text { separability }\end{array}$ & $\begin{array}{c}\text { Average } \\
\text { separability }\end{array}$ & $\begin{array}{c}\text { Class pair with } \\
\text { minimum separability }\end{array}$ \\
\hline $\begin{array}{l}\text { SWIR + PC } 1+ \\
\text { PC TEX + NDVI }\end{array}$ & 1.81 & 1.92 & $\begin{array}{c}\text { Alder and Willow- } \\
\text { horsetail }\end{array}$ \\
\hline $\begin{array}{l}\text { SWIR + PC1 + } \\
\text { PC TEX + SAVI }\end{array}$ & 1.79 & 1.92 & $\begin{array}{l}\text { Alder and Willow- } \\
\text { horsetail }\end{array}$ \\
\hline $\begin{array}{l}\text { SWIR + PCl + } \\
\text { PC TEX + MSAVI }\end{array}$ & 1.85 & 1.94 & $\begin{array}{l}\text { Alder and Willow- } \\
\text { horsetail }\end{array}$ \\
\hline$\overline{P C 1-4+P C \_T E X}$ & 1.91 & 1.96 & $\begin{array}{l}\text { Alder and Willow- } \\
\text { horsetail }\end{array}$ \\
\hline Central delta & $\begin{array}{c}\text { Minimum } \\
\text { separability }\end{array}$ & $\begin{array}{c}\text { Average } \\
\text { separability }\end{array}$ & $\begin{array}{c}\text { Class pair with } \\
\text { minimum separability }\end{array}$ \\
\hline $\begin{array}{l}\text { SWIR + Green + } \\
\text { PC TEX + NDVI }\end{array}$ & 1.77 & 1.87 & Alder and Spruce \\
\hline $\begin{array}{l}\text { SWIR + Green + } \\
\text { PC TEX + SAVI } \\
\end{array}$ & 1.78 & 1.87 & Alder and Spruce \\
\hline $\begin{array}{l}\text { SWIR + Green + } \\
\text { PC TEX + MSAVI }\end{array}$ & 1.82 & 1.89 & Alder and Spruce \\
\hline $\begin{array}{l}\text { SWIR + PC3 + } \\
\text { PC TEX + MSAVI } \\
\end{array}$ & 1.81 & 1.91 & Alder and Spruce \\
\hline Northern delta & $\begin{array}{c}\text { Minimum } \\
\text { separability }\end{array}$ & $\begin{array}{c}\text { Average } \\
\text { separability }\end{array}$ & $\begin{array}{c}\text { Class pair with } \\
\text { minimum separability }\end{array}$ \\
\hline $\begin{array}{l}\text { SWIR + PC1 + } \\
\text { PC TEX + NDVI }\end{array}$ & 1.87 & 1.96 & $\begin{array}{c}\text { Willow-horsetail and } \\
\text { Short willow }\end{array}$ \\
\hline $\begin{array}{l}\text { SWIR + PCl + } \\
\text { PC TEX + SAVI }\end{array}$ & 1.84 & 1.92 & $\begin{array}{l}\text { Willow-horsetail and } \\
\text { Short willow }\end{array}$ \\
\hline $\begin{array}{l}\text { SWIR + PCl + } \\
\text { PC TEX + MSAVI }\end{array}$ & 1.83 & 1.93 & $\begin{array}{l}\text { Willow-horsetail and } \\
\text { Short willow }\end{array}$ \\
\hline PC1-4 + PC_TEX & 1.83 & 1.89 & $\begin{array}{c}\text { Willow-horsetail and } \\
\text { Short willow }\end{array}$ \\
\hline
\end{tabular}


In the southern and central delta, the most appropriate vegetation index was MSAVI. In the northern delta, NDVI was the index with the best potential to increase separability between different vegetation classes. Table 6.6 also presents, for each image, an additional variable combination with high separability that was used in subsequent classifications.

\subsection{Classification analyses}

The two best combinations determined from separability analyses in Table 6.6 were used in classifications with MLC and ANN. The error matrices and classified maps are presented only for those classifications with the highest overall accuracy.

\subsubsection{Maximum Likelihood Classifications}

\subsubsection{Southern delta}

The two input variable combinations achieved very similar overall accuracy levels in the classifications of the following three vegetation classes: Willow-horsetail, Alder and Spruce. However, the PC1-4 + PC_TEX combination resulted in higher accuracy levels for the Willow-horsetail communities. Since these communities were characterized by absence of near-surface permafrost, the PC1-4 + PC_TEX combination will be discussed in more detail.

1) $\mathrm{PC} 1-4+$ PC_TEX

An overall accuracy of $84.2 \%$ was achieved for this combination involving all the four spectral principal components, the first eight MS texture components, and the first two Pan texture components. Table 6.7 shows the error matrix for this classification and 
Table 6.7 - Error matrix for the PC1-4 + PC_TEX classification of the southern delta. PC_TEX refers to the best texture combinations determined from Table 6.5. Overall accuracy $=84.2 \%$.

\begin{tabular}{|c|c|c|c|c|}
\hline & Alder & Spruce & Willow-horsetail & $\begin{array}{c}\text { User's } \\
\text { accuracy (\%) }\end{array}$ \\
\hline Alder & 81 & 7 & 14 & 79.4 \\
\hline Spruce & 0 & 29 & 0 & 100.0 \\
\hline Willow-horsetail & 4 & 2 & 34 & 85.0 \\
\hline $\begin{array}{c}\text { Producer's } \\
\text { accuracy (\%) }\end{array}$ & 95.3 & 76.3 & 70.8 & $\mathbf{8 4 . 2}$ \\
\hline
\end{tabular}

Table 6.8 - Error matrix for the SWIR + Green + PC_TEX + MSAVI classification of the central delta. Overall accuracy $=82.4 \%$.

\begin{tabular}{|c|c|c|c|c|}
\hline & Alder & Spruce & Willow-horsetail & $\begin{array}{c}\text { User's } \\
\text { accuracy (\%) }\end{array}$ \\
\hline Alder & 46 & 0 & 8 & 85.1 \\
\hline Spruce & 2 & 43 & 0 & 95.5 \\
\hline Willow-horsetail & 20 & 1 & 57 & 73.1 \\
\hline $\begin{array}{c}\text { Producer's } \\
\text { accuracy (\%) }\end{array}$ & 67.6 & 97.2 & 87.6 & $\mathbf{8 2 . 4}$ \\
\hline
\end{tabular}

Table 6.9 - Error matrix for the SWIR + PC1 + PC_TEX + NDVI classification of the northern delta. Overall accuracy $=83.4 \%$.

\begin{tabular}{|c|c|c|c|c|c|}
\hline & $\begin{array}{c}\text { Horsetail- } \\
\text { sedge }\end{array}$ & $\begin{array}{c}\text { Willow- } \\
\text { horsetail }\end{array}$ & Short willow & $\begin{array}{c}\text { Bare } \\
\text { ground }\end{array}$ & $\begin{array}{c}\text { User's } \\
\text { accuracy } \\
\text { (\%) }\end{array}$ \\
\hline Horsetail-sedge & 47 & 4 & 3 & 2 & 83.9 \\
\hline Willow-horsetail & 3 & 29 & 8 & 0 & 72.5 \\
\hline Short willow & 3 & 6 & 31 & 0 & 77.5 \\
\hline Bare ground & 0 & 0 & 0 & 39 & 100.0 \\
\hline $\begin{array}{c}\text { Producer's } \\
\text { accuracy(\%) }\end{array}$ & 88.6 & 74.4 & 73.8 & 95.1 & $\mathbf{8 3 . 4}$ \\
\hline
\end{tabular}


also presents producer's and user's accuracy levels. The sample size distribution was dominated by the Alder class which could have led to higher accuracies for Alder compared to Willow-horsetail. All errors of omission for the Willow-horsetail class occurred in misclassification as alders. Dominant errors of commission for Willowhorsetail also occurred when alders were incorrectly classified as willows and horsetails. The situation was similar for the Alder class with dominant errors of omission and commission occurring in misclassification with the Willow-horsetail class. Although the producer of the classification can reasonably claim that $95 \%$ of areas classified as Alder are correctly classified, a user would find that only $79 \%$ of Alder sites are correctly classified. For the Willow-horsetail class, the user's accuracy was $85 \%$ and was much higher than the producer's accuracy.

Most of the errors of omission for spruce forests were in misclassification as alders but there was no error of commission. The lower producer's accuracy for the Spruce class compared to $100 \%$ user's accuracy could come from the limited amount of original training data. The extension of spruce training data in small blocks could have included alder shrubs that are widespread in those forests, especially for those with opencanopy cover. Since the Spruce class had a high user's accuracy level, it is highly probable that areas classified as Spruce are truly of that category. Figure 6.2 shows the map of the southern delta classified using this input combination.

2) SWIR + PC1 + PC_TEX + MSAVI

An overall classification accuracy of $83.4 \%$ was achieved for this combination. There was less confusion between the Alder and Spruce classes but more confusion between the Willow-horsetail and Alder classes. The confusion between alders and 
a)

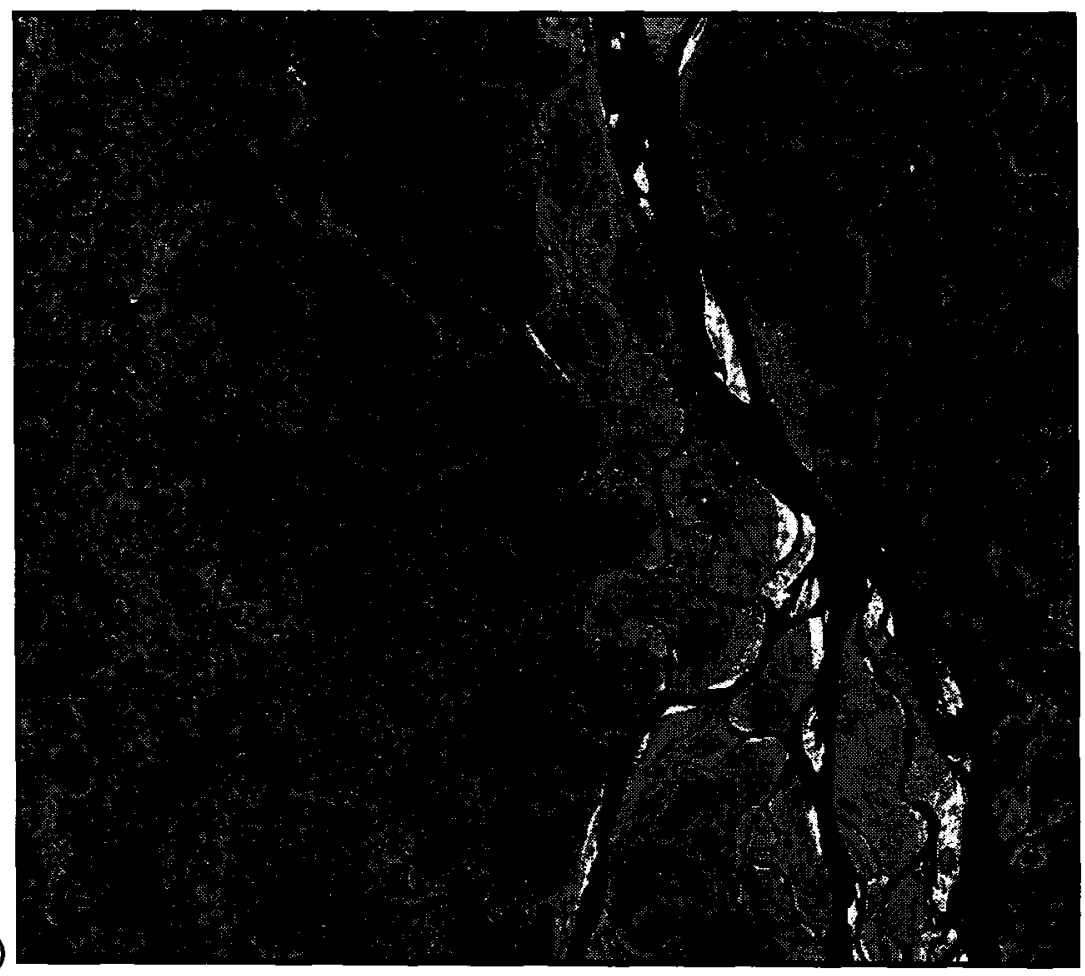

b)

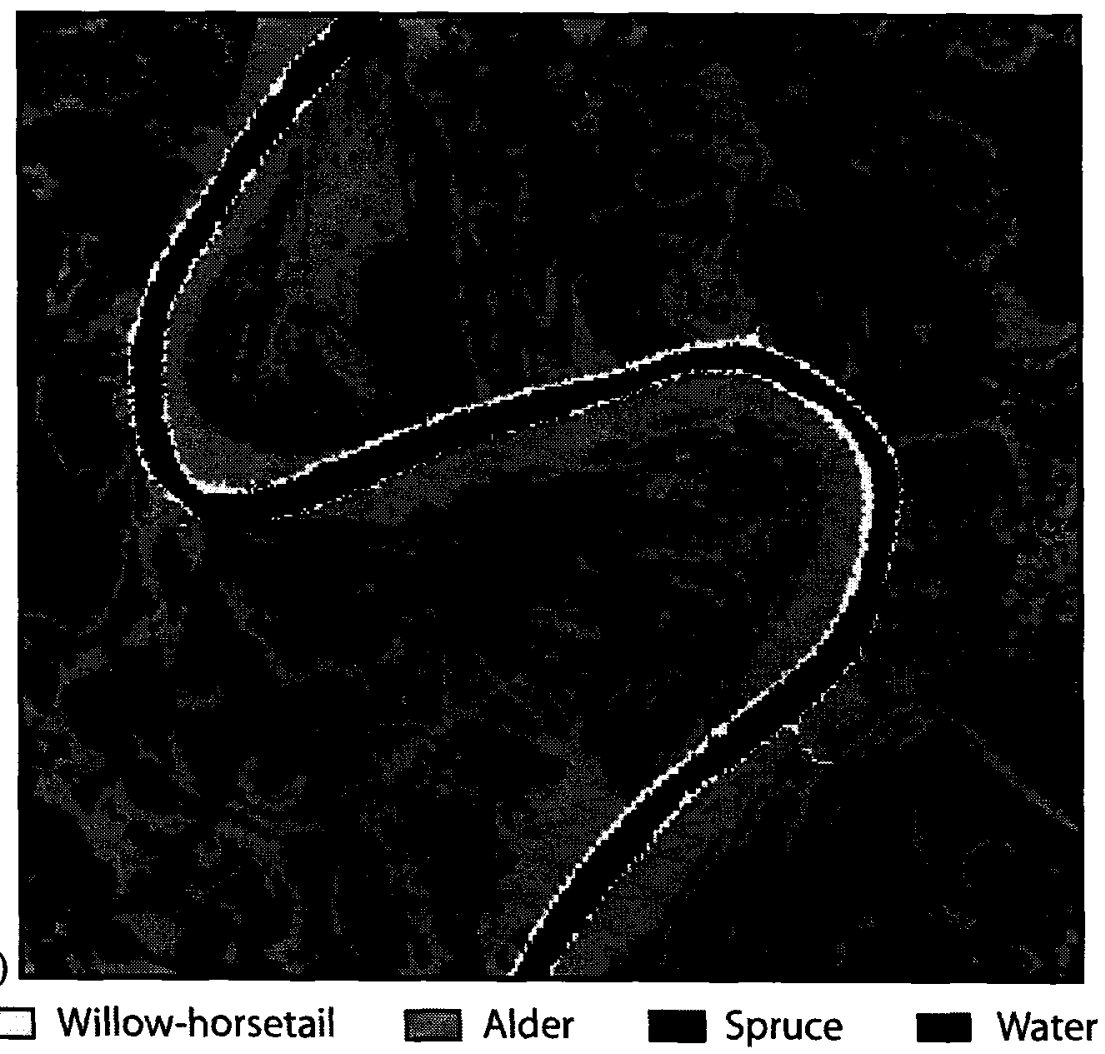

Fig. 6.2 - The southern delta classified using the best MLC results: a) overview map, and b) close-up on a point bar. 
spruce forests is not as important for this study since they were both characterized by presence of near-surface permafrost. However, confusion between alders and willows is more critical since permafrost was absent in Willow-horsetail zones.

\subsubsection{Central delta}

In the central delta, the SWIR + Green + PC_TEX + MSAVI input variable combination achieved a slightly better overall accuracy compared to the SWIR + PC3 + PC_TEX + MSAVI in the classifications of the Willow-horsetail, Alder and Spruce classes. Although, the SWIR + PC3 + PC_TEX + MSAVI combination had a higher separability of training data, it did not result in better classification accuracy. Dillabaugh and King (2005) also determined that while separability can aid in input variable selection and give a general idea of relative potential for classification accuracy, it is not an absolute indicator of final accuracy.

1) SWIR + Green + PC_TEX + MSAVI

An overall accuracy of $82.4 \%$ was achieved using the SWIR and Green bands, the first seven MS texture components, and the first four Pan texture components as well as the MSAVI as input. Table 6.8 shows the error matrix for this classification. All errors of omission for the Willow-horsetail class occurred in misclassification as alders. Dominant errors of commission for Willow-horsetail also occurred when alders were incorrectly classified as willows and horsetails. Although the producer's accuracy for alders was $68 \%$, a user of this classification would find that $85 \%$ of Alder sites are correctly classified. The situation is reversed for the Willow-horsetail class with a lower user's accuracy at $73 \%$. Spruce was a highly reliable category from both a producer's and a 
user's perspective with accuracy levels above $90 \%$. Figure 6.3 shows the map of the central delta classified using this input combination.

2) SWIR + PC3 + PC_TEX + MSAVI

An overall classification accuracy of $79.8 \%$ was achieved for this combination. While spruce forests had similarly high accuracies compared to the first input variable combination, both Alder and Willow-horsetail classes had lower accuracies. User's accuracies for the Willow-horsetail and Alder classes were $69 \%$ and $86 \%$, respectively. Producer's accuracy for the Willow-horsetail class was $87 \%$ and for the Alder class, it was $63 \%$.

\subsubsection{Northern delta}

The input combination of SWIR + PC1 + PC_TEX + NDVI achieved the best overall accuracy at $83.4 \%$. However, this level was biased considering the high accuracy of the Bare ground class which only occupied a small proportion of the land pixels. Without the Bare ground class, the overall accuracy was $78.7 \%$.

1) $S W I R+P C 1+$ PC_TEX + NDVI

This combination included the SWIR band, the first spectral principal component, the first seven MS texture components, the first five Pan texture components, and NDVI. Table 6.9 shows the error matrix for this classification. The greatest confusion occurred between the Willow-horsetail and the Short willow class as expected from LAI data analyses. The only reliable category associated with this classification from both a producer's and a user's perspective was the Horsetail-sedge class. For both the Willowhorsetail and Short willow classes, accuracy levels were below $80 \%$. Figure 6.4 shows 

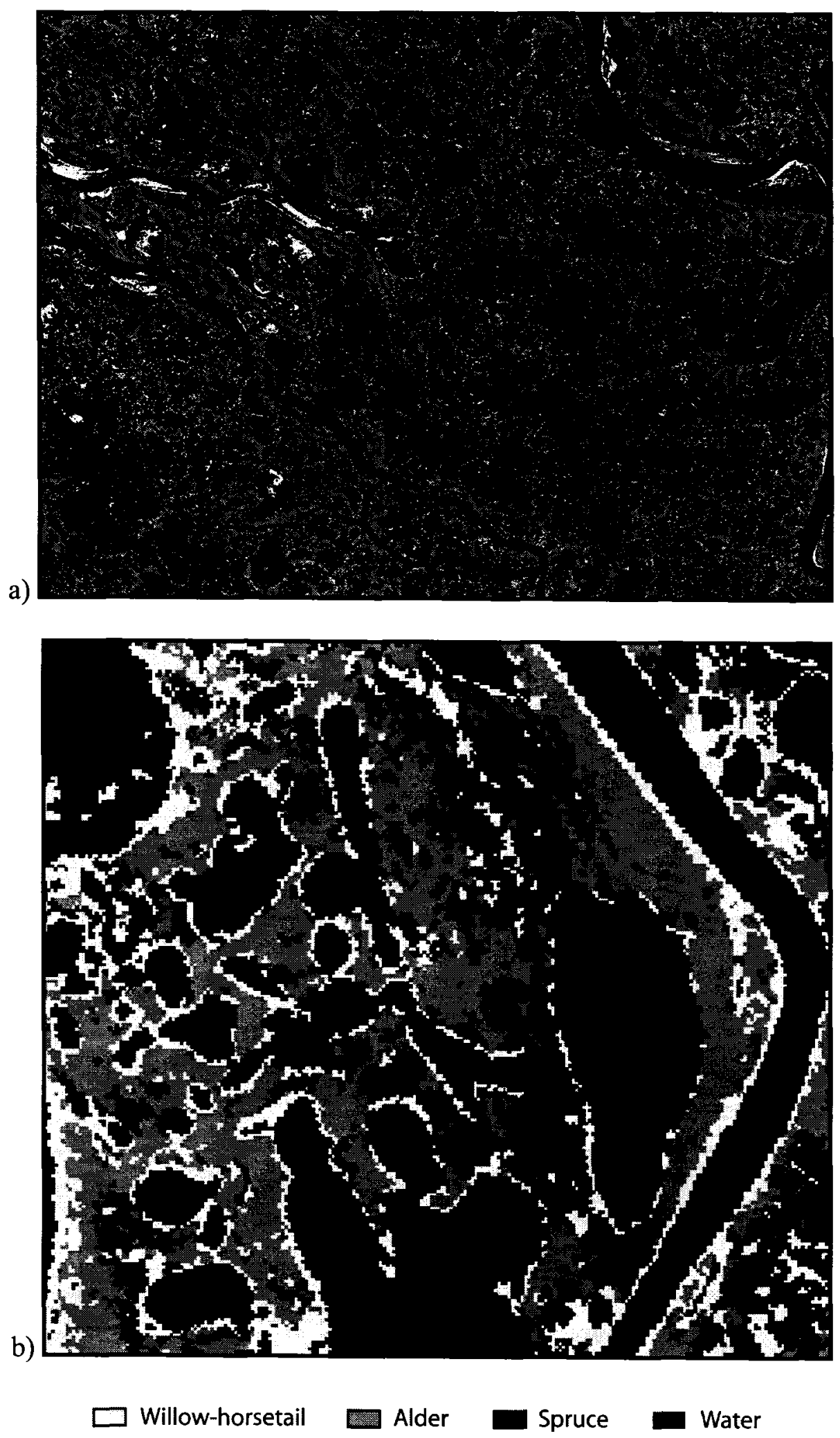

Fig. 6.3 - The central delta classified using the best MLC results: a) overview map, and

b) close-up on a point bar. 
a)

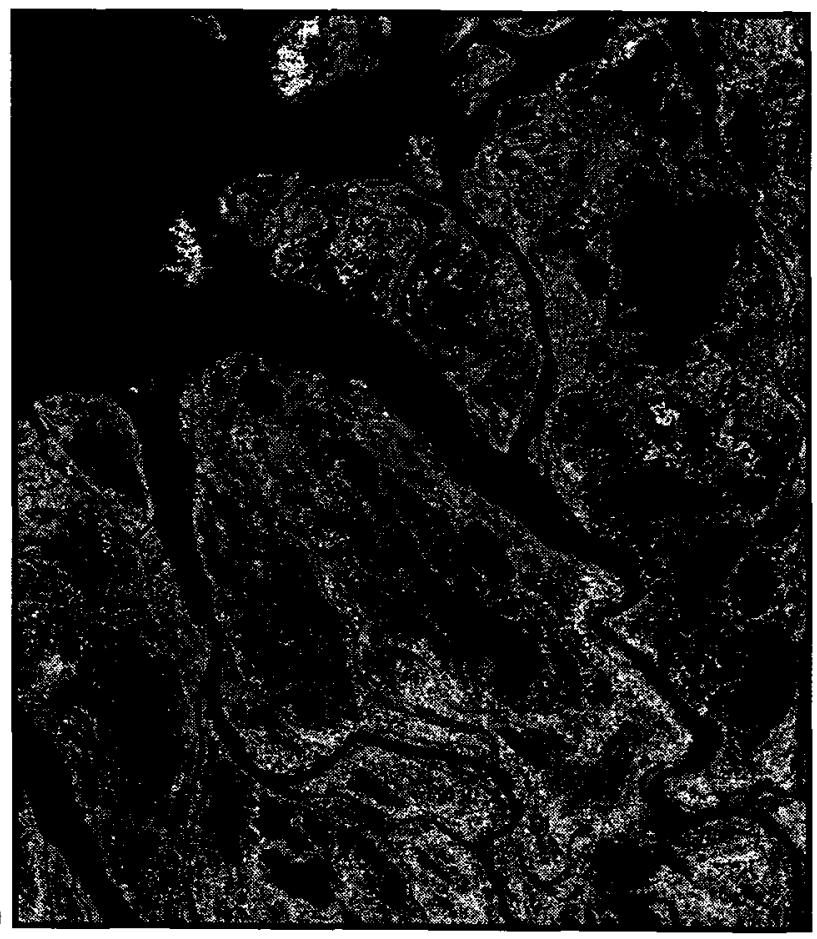

b)

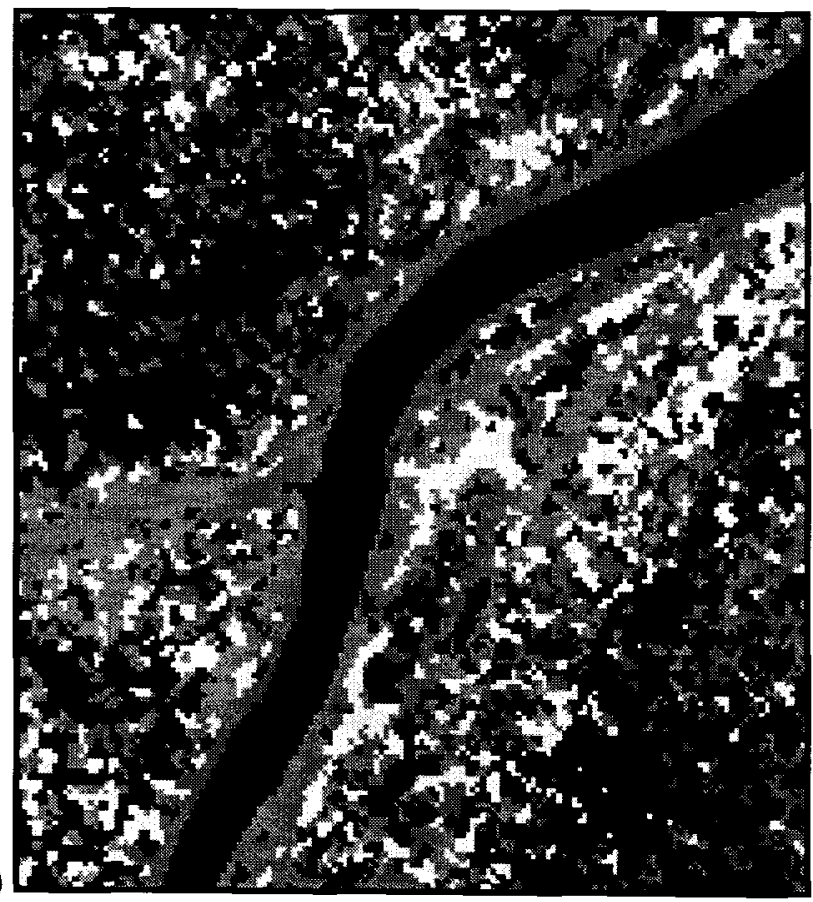

Fig. 6.4 - The northern delta classified using the best MLC results: a) overview map, and b) close-up on a point bar. 
the map of the northern delta classified using this input combination. As seen in the field, Horsetail-sedge dominates on channel edges and Short willow is the main vegetation class at slightly more elevated locations furthest away from channels. However, compared to Figs. 6.2 and 6.3, Willow-horsetail zones in Fig. 6.4 are patchier and probably reflect the lower overall accuracy.

2) $\mathrm{PC} 1-4+$ PC_TEX

An overall classification accuracy of $72.3 \%$ was achieved for this combination without the Bare ground class. The most significant difference with the previous combination was that dominant errors of commission and of omission of both Willowhorsetail and Short willow classes were with the Horsetail-sedge class. Although the Short willow class achieved slightly higher accuracy levels, both Willow-horsetail and Horsetail-sedge classes had significantly lower accuracies.

\subsubsection{Artificial Neural Network (ANN) classifications}

Tables 6.10-6.12 summarize the different ANN configurations as well as individual and total error levels achieved by each ANN. For all three images, none of the ANNs tested fully converged to achieve both the maximum allowable individual and total errors. However, the total error achieved was acceptable in many cases. For the southern delta, ANN S9 gave the best overall accuracy (83.6\%) but this achieved accuracy was slightly below the best MLC accuracy ( $84.2 \%$ ). Compared to the best MLC results, S9 was better in classifying spruce forests and alders. However, its performance in classifying the Willow-horsetail class was significantly worse (Table 6.13). There was great confusion between the important Alder and the Willow-horsetail class pairs. 
Table 6.10 - Tested neural network configurations and achieved error levels for the southern delta image.

\begin{tabular}{|c|c|c|c|c|c|c|}
\hline $\begin{array}{c}\text { ANN } \\
\text { ID }\end{array}$ & Input & Momentum & $\begin{array}{l}\text { Learning } \\
\text { rate }\end{array}$ & $\begin{array}{c}\text { Maximum } \\
\text { iterations }\end{array}$ & $\begin{array}{c}\text { Highest } \\
\text { individual } \\
\text { class error }\end{array}$ & $\begin{array}{c}\text { Total } \\
\text { error } \\
\text { achieved }\end{array}$ \\
\hline S1 & $\begin{array}{l}\mathrm{PC} 1-4+ \\
\mathrm{PC} \text { TEX } \\
\end{array}$ & 0.9 & 0.1 & 1000 & 0.36 & 0.01 \\
\hline S2 & $\begin{array}{l}\text { PC1-4+ } \\
\text { PC TEX }\end{array}$ & 0.6 & 0.2 & 1000 & 0.54 & 0.02 \\
\hline S3 & $\begin{array}{l}\mathrm{PC} 1-4+ \\
\mathrm{PC} \text { TEX }\end{array}$ & 0.9 & 0.1 & 100000 & 0.45 & 0.01 \\
\hline S4 & $\begin{array}{l}\text { PC1-4 + } \\
\text { PC TEX }\end{array}$ & 0.6 & 0.2 & 100000 & 0.33 & 0.01 \\
\hline S5 & $\begin{array}{l}\mathrm{PC} 1-4+ \\
\mathrm{PC} \text { TEX }\end{array}$ & 0.6 & 0.2 & 250000 & 0.33 & 0.01 \\
\hline S6 & $\begin{array}{c}\text { SWIR + PCl } \\
+ \text { PC TEX + } \\
\text { MSAVI }\end{array}$ & 0.9 & 0.1 & 1000 & 0.35 & 0.02 \\
\hline S7 & $\begin{array}{c}\text { SWIR + PCl } \\
+ \text { PC TEX + } \\
\text { MSAVI } \\
\end{array}$ & 0.6 & 0.2 & 1000 & 0.63 & 0.02 \\
\hline S8 & $\begin{array}{c}\text { SWIR + PC1 } \\
+ \text { PC TEX + } \\
\text { MSAVI }\end{array}$ & 0.9 & 0.1 & 100000 & 0.30 & 0.01 \\
\hline S9 & $\begin{array}{c}\text { SWIR + PC1 } \\
+ \text { PC TEX + } \\
\text { MSAVI } \\
\end{array}$ & 0.6 & 0.2 & 100000 & 0.27 & 0.01 \\
\hline S10 & $\begin{array}{c}\text { SWIR + PCl } \\
+ \text { PC_TEX + } \\
\text { MSAVI }\end{array}$ & 0.6 & 0.2 & 250000 & 0.30 & 0.01 \\
\hline
\end{tabular}


Table 6.11 - Tested neural network configurations and achieved error levels for the central delta image.

\begin{tabular}{|c|c|c|c|c|c|c|}
\hline $\begin{array}{l}\text { ANN } \\
\text { ID }\end{array}$ & Input & Momentum & $\begin{array}{l}\text { Learning } \\
\text { rate }\end{array}$ & $\begin{array}{l}\text { Maximum } \\
\text { iterations }\end{array}$ & $\begin{array}{c}\text { Highest } \\
\text { individual } \\
\text { class error }\end{array}$ & $\begin{array}{c}\text { Total } \\
\text { error } \\
\text { achieved }\end{array}$ \\
\hline $\mathrm{C} 1$ & $\begin{array}{c}\text { SWIR + } \\
\text { Green }+ \\
\text { PC_TEX }+ \\
\text { MSAVI }\end{array}$ & 0.9 & 0.1 & 1000 & 0.35 & 0.02 \\
\hline $\mathrm{C} 2$ & $\begin{array}{c}\text { SWIR + } \\
\text { Green + } \\
\text { PC_TEX + } \\
\text { MSAVI }\end{array}$ & 0.6 & 0.2 & 1000 & 0.33 & 0.02 \\
\hline $\mathrm{C} 3$ & $\begin{array}{c}\text { SWIR + } \\
\text { Green }+ \\
\text { PC_TEX }+ \\
\text { MSAVI }\end{array}$ & 0.9 & 0.1 & 100000 & 0.30 & 0.01 \\
\hline $\mathrm{C} 4$ & $\begin{array}{c}\text { SWIR + } \\
\text { Green }+ \\
\text { PC_TEX }+ \\
\text { MSAVI }\end{array}$ & 0.6 & 0.2 & 100000 & 0.29 & 0.01 \\
\hline $\mathrm{C} 5$ & $\begin{array}{c}\text { SWIR + } \\
\text { Green }+ \\
\text { PC_TEX }+ \\
\text { MSAVI }\end{array}$ & 0.6 & 0.2 & 250000 & 0.29 & 0.01 \\
\hline C6 & $\begin{array}{c}\text { SWIR + PC3 } \\
+ \text { PC_TEX + } \\
\text { MSAVI } \\
\end{array}$ & 0.9 & 0.1 & 1000 & 0.39 & 0.02 \\
\hline $\mathrm{C} 7$ & $\begin{array}{c}\text { SWIR + PC3 } \\
+ \text { PC_TEX + } \\
\text { MSAVI }\end{array}$ & 0.6 & 0.2 & 1000 & 0.33 & 0.02 \\
\hline $\mathrm{C} 8$ & $\begin{array}{c}\text { SWIR + PC3 } \\
+ \text { PC TEX + } \\
\text { MSAVI }\end{array}$ & 0.9 & 0.1 & 100000 & 0.34 & 0.01 \\
\hline C9 & $\begin{array}{c}\text { SWIR + PC3 } \\
+ \text { PC_TEX + } \\
\text { MSAVI }\end{array}$ & 0.6 & 0.2 & 100000 & 0.33 & 0.01 \\
\hline $\mathrm{C} 10$ & $\begin{array}{c}\text { SWIR + PC3 } \\
+ \text { PC_TEX + } \\
\text { MSAVI }\end{array}$ & 0.6 & 0.2 & 250000 & 0.29 & 0.01 \\
\hline
\end{tabular}


Table 6.12 - Tested neural network configurations and achieved error levels for the northern delta image.

\begin{tabular}{|c|c|c|c|c|c|c|}
\hline $\begin{array}{l}\text { ANN } \\
\text { ID }\end{array}$ & Input & Momentum & $\begin{array}{c}\text { Learning } \\
\text { rate }\end{array}$ & $\begin{array}{l}\text { Maximum } \\
\text { iterations }\end{array}$ & $\begin{array}{l}\text { Highest } \\
\text { individual } \\
\text { class error }\end{array}$ & $\begin{array}{c}\text { Total } \\
\text { error } \\
\text { achieved }\end{array}$ \\
\hline $\mathrm{N} 1$ & $\begin{array}{l}\text { PC1-4+ } \\
\text { PC TEX }\end{array}$ & 0.9 & 0.1 & 1000 & 0.35 & 0.01 \\
\hline $\mathrm{N} 2$ & $\begin{array}{l}\text { PCl-4+ } \\
\text { PC TEX }\end{array}$ & 0.6 & 0.2 & 1000 & 0.35 & 0.02 \\
\hline N3 & $\begin{array}{l}\text { PC1-4+ } \\
\text { PC TEX }\end{array}$ & 0.9 & 0.1 & 100000 & 0.30 & 0.01 \\
\hline $\mathrm{N} 4$ & $\begin{array}{l}\text { PCl-4+ } \\
\text { PC_TEX }\end{array}$ & 0.6 & 0.2 & 100000 & 0.29 & 0.01 \\
\hline N5 & $\begin{array}{l}\text { PC1-4 + } \\
\text { PC TEX }\end{array}$ & 0.6 & 0.2 & 250000 & 0.30 & 0.01 \\
\hline N6 & $\begin{array}{c}\text { SWIR + PCl } \\
+ \text { PC_TEX + } \\
\text { NDVI }\end{array}$ & 0.9 & 0.1 & 1000 & 0.32 & 0.02 \\
\hline N7 & $\begin{array}{c}\text { SWIR + PC1 } \\
+ \text { PC_TEX + } \\
\text { NDVI }\end{array}$ & 0.6 & 0.2 & 1000 & 0.97 & 0.02 \\
\hline N8 & $\begin{array}{c}\text { SWIR + PC1 } \\
+ \text { PC_TEX + } \\
\text { NDVI }\end{array}$ & 0.9 & 0.1 & 100000 & 0.29 & 0.01 \\
\hline N9 & $\begin{array}{c}\text { SWIR + PC1 } \\
+ \text { PC_TEX + } \\
\text { NDVI } \\
\end{array}$ & 0.6 & 0.2 & 100000 & 0.28 & 0.01 \\
\hline N10 & $\begin{array}{c}\text { SWIR + PC1 } \\
+ \text { PC_TEX + } \\
\text { NDVI }\end{array}$ & 0.6 & 0.2 & 250000 & 0.29 & 0.01 \\
\hline
\end{tabular}


Table 6.13 - Producer and user accuracies for the best ANN tested for each image. The ANN ID is provided in brackets.

\begin{tabular}{|c|c|c|}
\hline Southern delta (S9) & Producer's accuracy (\%) & User's accuracy (\%) \\
\hline Alder & 81.6 & 94.6 \\
\hline Willow-horsetail & 78.1 & 58.1 \\
\hline Spruce & 96.7 & 93.5 \\
\hline \multicolumn{3}{|c|}{} \\
\hline Central delta (C4) & Producer's accuracy (\%) & User's accuracy (\%) \\
\hline Alder & 67.6 & 79.3 \\
\hline Willow-horsetail & 59.4 & 78.8 \\
\hline Spruce & 100.0 & 62.0 \\
\hline \multicolumn{3}{|c|}{} \\
\hline Northern delta (N4) & Producer's accuracy (\%) & User's accuracy (\%) \\
\hline Horsetail-sedge & 69.4 & 73.9 \\
\hline Willow-horsetail & 75.0 & 96.8 \\
\hline Short willow & 79.4 & 58.7 \\
\hline Bare ground & 97.5 & 93.1 \\
\hline
\end{tabular}


For the central delta mosaic, the best overall accuracy was achieved by ANN C4 (72.4\%) (Table 6.13). This is clearly below the best MLC performance $(82.4 \%)$. Significant differences with the MLC results included a much lower user's accuracy for spruce forests and lower producer's accuracy for the Willow-horsetail class. Similar to the MLC results, there was confusion between the Alder and Willow-horsetail classes. However, there were also important commission errors for the Spruce class as a high number of Willow-horsetail pixels were improperly included in the Spruce category.

The best ANN classification for the northern delta image resulted from the ANN N4 configuration with an overall accuracy of $74 \%$ (Table 6.13 ). This is also below the best MLC performance ( $83.4 \%$ ). Producer's and user's accuracies for the Horsetail-sedge class were much lower. However, classification of Willow-horsetail by ANN N4 was significantly better compared to the best MLC. Another noticeable difference was the much lower user's accuracy achieved for the Short willow class.

In summary, overall classification accuracies were lower for neural networks compared to the MLC results using the same vegetation classes. On the other hand, for some individual classes, accuracies achieved by ANNs were higher. The lower accuracies of ANN classifications may be attributed to the high variability of spectral reflectance of high-resolution SPOT-5 pixels over a regional scale. Mills et al. (2006) also found that the spectral variability of IKONOS pixels decreased the generalization ability of ANNs.

\subsubsection{Factors influencing classification accuracy}

Although the overall accuracies achieved by the best classifiers did not reach the $85 \%$ benchmark, they were adequate using the minimum map accuracy method (Wulder 
et al. 2006). Aside from obvious uncertainties related to positional accuracy of sampling plots as well as of ground control points used to georeference the images, other factors such as the relatively small width of riparian vegetation zones, shadow, and intra-class spectral heterogeneity could also influence the classification accuracies. The small width of vegetation zones such as Horsetail and Willow-horsetail was a problem that has been discussed in many wetlands and riparian vegetation mapping studies (e.g. Johansen and Phinn 2006). Narrow vegetation zones in deltas have higher perimeter-to-area ratios, which will increase the potential of spectral heterogeneity of pixels due to radiance mixing. Intra-class spectral heterogeneity over a regional scale is also a factor affecting classification accuracies. In spruce zones, for example, alder and willow shrubs are the main understorey vegetation and may influence the spectral reflectance of spruce trees in open-canopy forests.

The effect of shadow is another potential problem in remote sensing in the Arctic. The Mackenzie Delta experiences long hours of daylight for much of the summer but at low sun angles. Thus, any vertically growing plants will cast relatively long shadows. Shadows represent lower incident, and therefore, reflected radiation which can lower the spectral response of a particular land cover. In addition, vegetation zones close to shorelines experience variable water levels and therefore, can have a high degree of wetness. Since water is highly absorptive of electromagnetic radiation in certain bands, wetness can also play a role in reducing the spectral response of affected vegetation classes. 


\subsubsection{Linear spectral unmixing}

Figure 6.5 shows the fraction images resulting from linear spectral unmixing analysis for the southern delta image. Visually, they appeared correct with greater brightness for fraction image $\mathrm{X}$ in locations where an endmember $\mathrm{X}$ was more prevalent. Comparison of Figs. 6.2 and 6.5a indicates that Willow-horsetail vegetation was more widespread using spectral unmixing. With MLC-derived maps, Alder zones appeared more extensive and the presence of Willows-horsetail patches within these zones was veiled by the dominant alders. Since willows and horsetails were dominant in narrow bands near shorelines, they did not clearly appear in neither Fig. 6.2 nor Fig. 6.5a, with the exception of the alluvial islands by Middle Channel. Fig. $6.5 \mathrm{c}$ also shows a greater presence of spruce throughout the southern delta image. However, there was no way to validate the fraction values calculated for each pixel with the lack of vegetation sampling in transition zones.

The purity of training data used as endmembers as well as the vegetation gradation from one community to another could be examined with spectral unmixing. Figure 6.6 shows the relation between the fraction image values and classified vegetation zones along the SD3 transect. It indicates that, at the centre of each vegetation zone at pixels 0,8 , and 16 , although the dominant vegetation was correctly used to classify each zone, the training data used were composed of a mixture of endmembers. However, this does not necessary mean that there was radiance mixing from different vegetation classes in these pixels. It could be possible that the radiance from a single class overlaps spectrally with another class and, in unmixing all classes, that overlap resulted in a mixed signature for these pixels. The gradation of vegetation from one zone to another, with 
a)
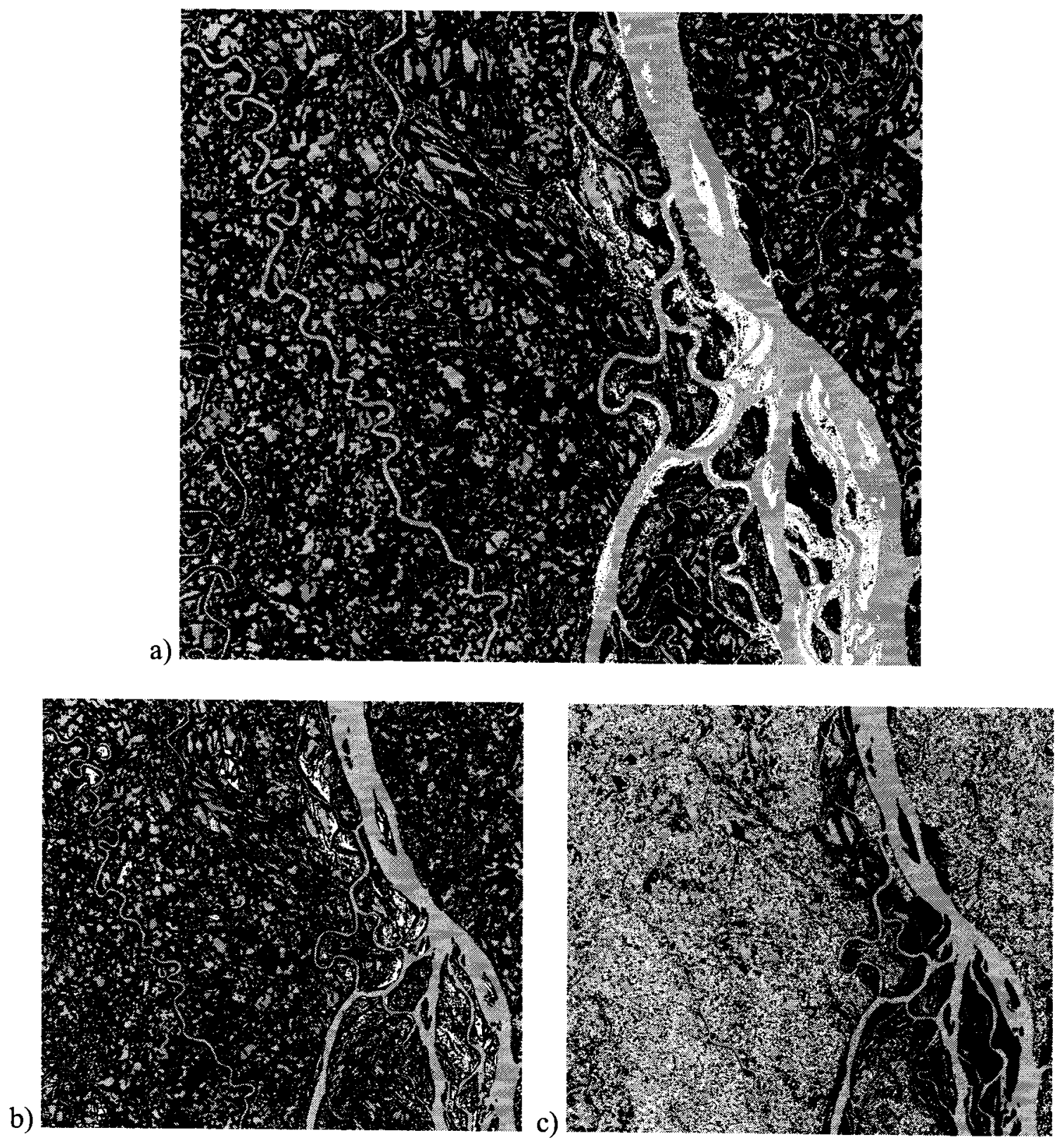

Fraction

0.0 1.0

Fig. 6.5 - Fraction images of the a) Willow-horsetail; b) Alder; and c) Spruce endmembers for the southern delta image. Water was masked out in blue. 


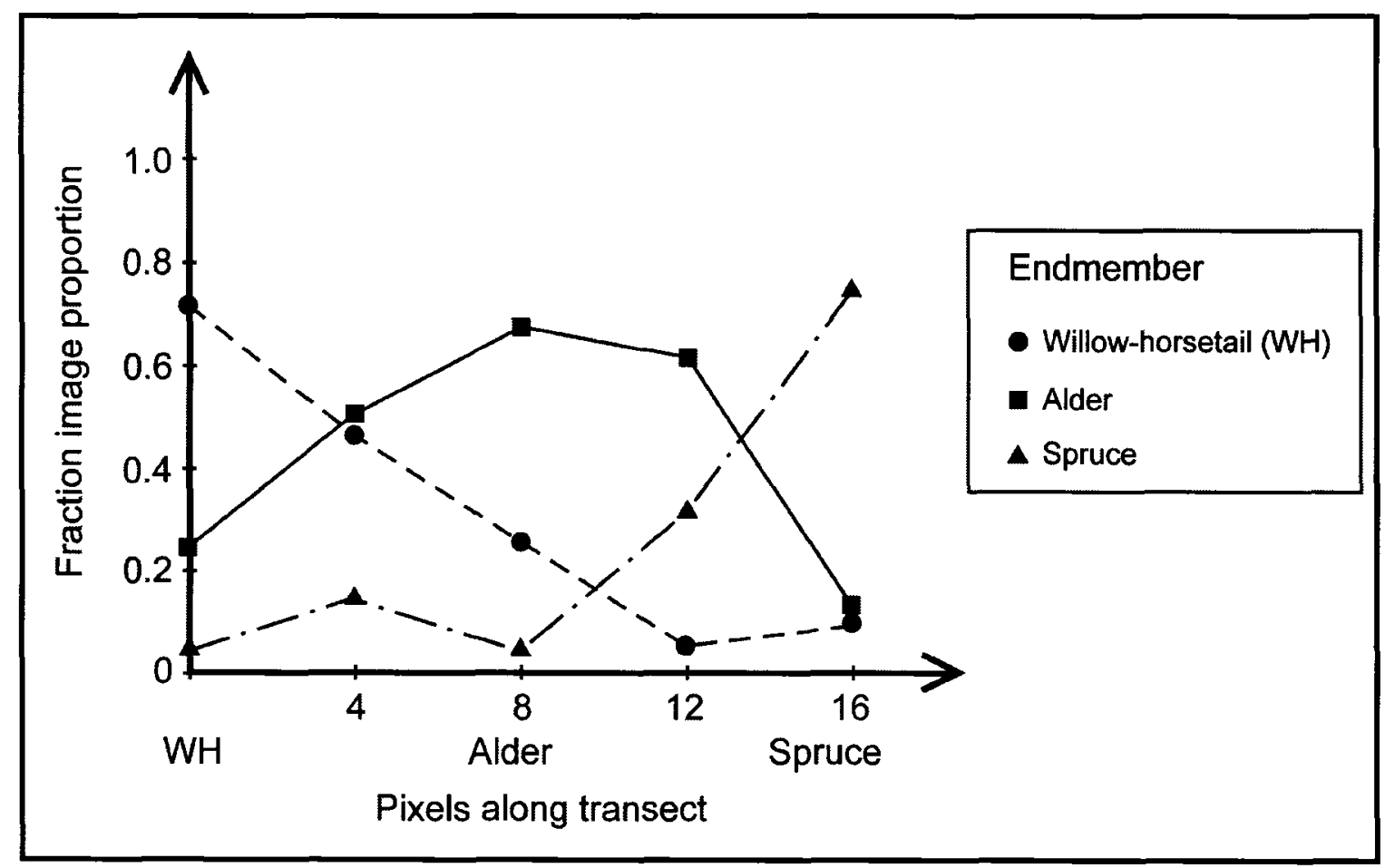

Fig. 6.6 - SD3 transect of vegetation fraction image proportion showing the relation between image values and classified vegetation zones. Training data used as endmembers were centred at pixels 0,8 , and 16. For the location of this transect, see Fig. 3.9. 
transitions zones centred at pixels 4 and 12, was also visible. In Willow-horsetail to Alder transition window, there was a mixture of willows, horsetails and alders. In the transition zone between Alder and Spruce, alders were still dominant but the presence of spruce trees was also clearly noticeable.

\subsection{Estimation of near-surface permafrost extent}

The land surface can be categorized into three types: (1) Alluvial islands (AI), (2) Point bars (PB), and (3) all other classes. Alluvial islands, only present in the southern delta, occupy approximately $5 \%$ of the land pixels and therefore, its land fraction (LF) is equal to 0.05 . Point bars represent up to $18 \%$ of the land surface with a LF of 0.18 (Pearce 1986). The rest of the land surface has a LF value of 0.77 in the southern delta and 0.82 in the central and northern delta. The extent of near-surface permafrost, in each delta region, can be calculated as the total for all land types of the percentage of the land surface occupied by vegetation classes associated with presence of permafrost (VEG_PMF) multiplied by the land fraction of the land type:

$$
\text { VEG_PMF * } \mathrm{LF}_{\mathrm{AI}}+\mathrm{VEG} \_\mathrm{PMF} * \mathrm{LF}_{\mathrm{PB}}+\mathrm{VEG} \_\mathrm{PMF} * \mathrm{LF}_{\text {other }}
$$

Table 6.14 shows the total land area underlain by near-surface permafrost for each delta region. In the southern delta, $92.1 \%$ of the land surface is underlain by permafrost. Without the presence of alluvial islands, zones with presence of permafrost represent $94.6 \%$ and $96.3 \%$ of the land pixels in the central and northern delta, respectively.

Another possible way to estimate the extent of near-surface permafrost in the Delta is to use Table 4.8 with the percentages of drilled holes associated to presence of near-surface permafrost for each vegetation association in each delta region. With 
Table 6.14 - Area underlain by near-surface permafrost for each delta region.

\begin{tabular}{|c|c|c|c|}
\hline Southern delta & $\begin{array}{l}\% \text { ground covered } \\
\text { by }\end{array}$ & $\begin{array}{l}\text { Area underlain by } \\
\text { permafrost }\end{array}$ & $\begin{array}{c}\text { Total area } \\
\text { underlain by } \\
\text { permafrost }\end{array}$ \\
\hline \multicolumn{4}{|l|}{$A I(L F=0.05)$} \\
\hline Alder & 72.8 & 0 & \\
\hline Willow-horsetail & 17.1 & 0 & \\
\hline \multirow[t]{2}{*}{ Spruce } & 10.1 & $10.1 * 0.05$ & \\
\hline & & & 0.5 \\
\hline \multicolumn{4}{|l|}{$P B(\overline{L F}=0.18)$} \\
\hline Alder & 37.1 & $37.1 * 0.18$ & \\
\hline Willow-horsetail & 19.1 & 0 & \\
\hline \multirow[t]{2}{*}{ Spruce } & 43.8 & $43.8 * 0.18$ & \\
\hline & & & 14.6 \\
\hline \multicolumn{4}{|l|}{ Other $(L F=0.77)$} \\
\hline All classes & 100 & $100 * 0.77$ & 77.0 \\
\hline All land types & & & 92.1 \\
\hline Central delta & $\begin{array}{l}\% \text { ground covered } \\
\text { by }\end{array}$ & $\begin{array}{c}\text { Area underlain by } \\
\text { permafrost }\end{array}$ & $\begin{array}{c}\text { Total area } \\
\text { underlain by } \\
\text { permafrost }\end{array}$ \\
\hline \multicolumn{4}{|l|}{$P B(L F=0.18)$} \\
\hline Alder & 33.3 & $33.3 * 0.18$ & \\
\hline Willow-horsetail & 29.8 & 0 & \\
\hline \multirow[t]{2}{*}{ Spruce } & 36.9 & $36.9 * 0.18$ & \\
\hline & & & 12.6 \\
\hline \multicolumn{4}{|l|}{ Other $(L F=0.82)$} \\
\hline All classes & 100 & $100 * 0.82$ & 82.0 \\
\hline \multicolumn{4}{|l|}{ All land types } \\
\hline Northern delta & $\begin{array}{l}\% \text { ground covered } \\
\text { by }\end{array}$ & $\begin{array}{l}\text { Area underlain by } \\
\text { permafrost }\end{array}$ & $\begin{array}{c}\text { Total area } \\
\text { underlain by } \\
\text { permafrost }\end{array}$ \\
\hline \multicolumn{4}{|l|}{$P B(L F=0.18)$} \\
\hline Horsetail-sedge & 36.1 & $36.1 * 0.18$ & \\
\hline Willow-horsetail & 20.5 & 0 & \\
\hline Short willow & 42.6 & $42.6 * 0.18$ & \\
\hline \multirow[t]{2}{*}{ Bare ground } & 0.8 & $0.8 * 0.18$ & \\
\hline & & & 14.3 \\
\hline \multicolumn{4}{|l|}{ Other $(L F=0.82)$} \\
\hline All classes & 100 & $100 * 0.82$ & 82.0 \\
\hline All land types & & & 96.3 \\
\hline
\end{tabular}


this method, near-surface permafrost underlies $91.4 \%, 95.2 \%$, and $97.2 \%$ of the land surface in the southern, central, and northern delta, respectively (Table 6.15).

Since a zone of continuous permafrost is a zone where permafrost underlies more than $90 \%$ of the exposed ground, results of this research indicate that the Mackenzie Delta is part of the continuous permafrost zone. While the use of percentage cover in geographic characterization of permafrost is resolution-dependent, in permafrost maps at the national-scale where Landsat would be a more appropriate sensor, the Mackenzie Delta would also be classified as a continuous permafrost zone. At coarser scale than SPOT-5, the narrow bands of Willow-horsetail zones with absence of near-surface permafrost on point bars may not be detectable and those zones may be lumped in wider vegetation zones characterized by presence of near-surface permafrost.

\subsection{Summary of classification results}

Classification results indicate that the inclusion of texture information and vegetation indices was essential in the separability of different vegetation communities in the Mackenzie Delta. Input variable combinations comprising lowly-correlated spectral and textural variables led to classification of vegetation associations with accuracy levels of $84.2 \%, 82.4 \%$, and $83.4 \%$ for the southern, central, and northern delta images, respectively. In the southern and central delta, the greatest confusion was encountered between the Willow-horsetail and Alder classes. These two classes are both shrubby vegetation and are usually located in sequential order on point bars. In the northern delta, the greatest confusion occurred between the Willow-horsetail and the Short willow classes as expected from LAI data analyses. Overall classification accuracies were lower 
Table 6.15 - Extent of near-surface permafrost using percentages of positive drilled holes of Table 4.8.

\begin{tabular}{|c|c|c|c|c|}
\hline Southern delta & $\begin{array}{l}\% \text { ground } \\
\text { covered by }\end{array}$ & $\begin{array}{c}\text { Fraction of } \\
\text { positive } \\
\text { drilled holes }\end{array}$ & $\begin{array}{l}\text { Area underlain } \\
\text { by permafrost }\end{array}$ & $\begin{array}{c}\text { Total area } \\
\text { underlain by } \\
\text { permafrost }\end{array}$ \\
\hline \multicolumn{5}{|l|}{$A I(L F=0.05)$} \\
\hline Alder & 72.8 & 0 & $72.8 * 0.89 * 0.05$ & 0 \\
\hline Willow-horsetail & 17.1 & 0.02 & $17.1 * 0.02 * 0.05$ & 0.02 \\
\hline \multirow[t]{2}{*}{ Spruce } & 10.1 & 1.00 & $10.1 * 1 * 0.05$ & 0.5 \\
\hline & & & & 0.5 \\
\hline \multicolumn{5}{|l|}{$P B(L F=0.18)$} \\
\hline Alder & 37.1 & 0.89 & $37.1 * 0.89 * 0.18$ & 5.9 \\
\hline Willow-horsetail & 19.1 & 0.02 & $19.1 * 0.02 * 0.18$ & 0.1 \\
\hline \multirow[t]{2}{*}{ Spruce } & 43.8 & 1.00 & $43.8 * 1 * 0.18$ & 7.9 \\
\hline & & & & 13.9 \\
\hline \multicolumn{5}{|l|}{ Other $(L F=0.77)$} \\
\hline All classes & 100 & 1.00 & $100 * 0.77$ & 77.0 \\
\hline All land types & & & & 91.4 \\
\hline \\
\hline Central delta & $\begin{array}{l}\text { \% ground } \\
\text { covered by }\end{array}$ & $\begin{array}{c}\text { Fraction of } \\
\text { positive } \\
\text { drilled holes }\end{array}$ & $\begin{array}{l}\text { Area underlain } \\
\text { by permafrost }\end{array}$ & $\begin{array}{c}\text { Total area } \\
\text { underlain by } \\
\text { permafrost }\end{array}$ \\
\hline \multicolumn{5}{|l|}{$P B(L F=0.18)$} \\
\hline Alder & 33.3 & 0.98 & $33.3 * 0.98 * 0.18$ & 5.9 \\
\hline Willow-horsetail & 29.8 & 0.14 & $29.8 * 0.14 * 0.18$ & 0.7 \\
\hline \multirow[t]{2}{*}{ Spruce } & 36.9 & 1.00 & $36.9 * 1 * 0.18$ & 6.6 \\
\hline & & & & 13.2 \\
\hline \multicolumn{5}{|l|}{ Other $(L F=0.82)$} \\
\hline All classes & 100 & 1.00 & $100 * 0.82$ & 82.0 \\
\hline \multicolumn{5}{|l|}{ All land types } \\
\hline Northern delta & $\begin{array}{l}\% \text { ground } \\
\text { covered by }\end{array}$ & $\begin{array}{c}\text { Fraction of } \\
\text { positive } \\
\text { drilled holes }\end{array}$ & $\begin{array}{l}\text { Area underlain } \\
\text { by permafrost }\end{array}$ & $\begin{array}{c}\text { Total area } \\
\text { underlain by } \\
\text { permafrost }\end{array}$ \\
\hline \multicolumn{5}{|l|}{$P B(L F=0.18)$} \\
\hline Horsetail-sedge & 36.1 & 1.00 & $36.1 * 1 * 0.18$ & 6.5 \\
\hline Willow-horsetail & 20.5 & 0.25 & $20.5 * 0.25 * 0.18$ & 0.9 \\
\hline Short willow & 42.6 & 1.00 & $42.6 * 1 * 0.18$ & 7.7 \\
\hline \multirow[t]{2}{*}{ Bare ground } & 0.8 & 1.00 & $0.8 * 1 * 0.18$ & 0.1 \\
\hline & & & & 15.2 \\
\hline \multicolumn{5}{|l|}{ Other $(L F=0.82)$} \\
\hline All classes & 100 & & $100 * 0.82$ & 82.0 \\
\hline All land types & & & & 97.2 \\
\hline
\end{tabular}


for neural networks compared to the MLC results using the same vegetation classes. On the other hand, for some individual classes, accuracies achieved by ANNs were higher. Linear spectral unmixing provided complementary information to MLC by being particularly useful in studying vegetation gradation from one community to another.

Based on image data analysis results, it can be concluded that zones with presence of near-surface permafrost in the southern delta occupy $91.4-92.1 \%$ of the land surface. Zones with presence of near-surface permafrost represent 94.6-95.2\% and 96.3$97.2 \%$ of the land pixels in the central and northern delta, respectively. This indicates that the Mackenzie Delta is part of the continuous permafrost zone. 


\section{CHAPTER SEVEN}

\section{SUMMARY AND CONCLUSIONS}

\subsection{Summary of results}

This thesis investigated the proportion of the Mackenzie Delta, Northwest Territories, underlain by near-surface permafrost. Analyses of field results determined that vegetation communities on point bars, and on alluvial islands in the southern delta, were spatially associated with the presence or absence of near-surface permafrost. This thesis also established that SPOT-5 data can be used to map vegetation communities in the Delta with adequate accuracies. The resulting maps were used to estimate the extent of near-surface permafrost and to conclude that the Mackenzie Delta is part of the continuous permafrost zone. The permafrost classification resulting from this research is in agreement with classifications based on climate data from Brown (1967, 1973). However, it differs with the classification from Heginbottom et al. (1995), based on ground temperature data, categorizing the Delta as having discontinuous permafrost.

Since the presence of permafrost in the upper $3 \mathrm{~m}$ is important for engineering design and for understanding near-surface hydrology, this research could form the basis of a mapping tool that could be used to aid in land use planning and to monitor changes in permafrost conditions resulting from development or climate change. This chapter summarizes the relations between vegetation and near-surface permafrost as well as the remote sensing techniques that were used to map vegetation communities. Finally, some limitations of this research and recommendations for future research are outlined. 


\subsubsection{Vegetation and near-surface permafrost on point bars and alluvial islands}

Permafrost was absent from the upper $3 \mathrm{~m}$ of the ground beneath Horsetail communities in the southern and central delta, beneath Alder communities on alluvial islands in the southern delta, and beneath Willow-horsetail communities in all three delta regions. Permafrost was present beneath all other vegetation associations. Absence of near-surface permafrost, however, does not mean that permafrost does not exist at all as it may be present at greater depths or in a degrading state.

\subsubsection{Remote sensing of vegetation communities}

Classification of vegetation associations with overall accuracies of $84.2 \%, 82.4 \%$, and $83.4 \%$ were obtained for the southern, central, and northern delta image, respectively. Vegetation indices such as MSAVI and NDVI were found to be useful for discriminating between vegetation classes in the Delta. Texture information were found to improve classification accuracies. In the southern and central delta, the greatest confusion was encountered between the shrubby classes of Willow-horsetail and Alder. In the northern delta, dominant classification errors occurred between the Willowhorsetail and the Short willow classes. Overall accuracies were lower for artificial neural networks (ANN) compared to the Maximum Likelihood Classification (MLC) results using the same vegetation classes. However, for some individual classes, accuracies achieved by ANNs were higher.

\subsection{Conclusions}

Four conclusions can be drawn from results presented in this thesis: 
(1) On point bars and on alluvial islands, permafrost is absent from the upper $3 \mathrm{~m}$ beneath Horsetail zones in the southern and central delta, beneath Alder zones on alluvial islands in the southern delta, and beneath Willow-horsetail communities in all three regions. Permafrost was present beneath all other vegetation associations as well as at other geomorphic locations.

(2) NDVI and MSAVI as well as texture information were found to be useful for discriminating between vegetation communities and improving remote sensing data classification accuracy.

(3) Overall classification accuracies were lower for neural networks compared to the MLC results using the same vegetation classes, and spectral unmixing was useful in studying vegetation gradation from one community to another.

(4) Zones with presence of near-surface permafrost occupied 91.4-92.1\%, 94.6$95.2 \%$, and $96.3-97.2 \%$ of the land surface, in the southern, central, and northern delta, respectively. This indicates that the Mackenzie Delta is part of the continuous permafrost zone.

\subsection{Limitations of this research and recommendations for future research}

Due to time constraints and the remote environment of the Mackenzie Delta, a limitation of this research was in the spatial distribution of field sites. Although sampling sites were located in representative regions of the Delta, they were fairly clustered in each region. This reduced the capture of the spatial variations of spectral and textural characteristics of each vegetation community and may have resulted in greater class confusion. This clustered pattern also increased spatial autocorrelation of validation data 
and may have led to an overestimation of accuracy. However, a strength of this research was the substantial field component which included sampling sites in the southern and western central delta, locations with little data on permafrost conditions at present.

Another limitation of this research was the relatively low accuracy of ground control points used for image georeferencing. Due to the lack of artificial and easily distinguishable features on satellite images, because the region is sparsely populated, confluences of small channels were used as ground control points reducing accuracies in georeferencing.

Accuracy assessments for the classifications were performed with $2 \times 2$ validation datasets. These datasets were expanded when too few sampled plots existed by appending the four adjacent pixels of existing plots in the direction parallel to channels. This procedure increased spatial autocorrelation and could also introduce greater class confusion since the appended pixels might not be part of the same vegetation class.

For the estimation of the proportion of land surfaces underlain by permafrost, the extent of point bars was based on examination of aerial photographs carried out in the 1980s (Pearce 1986). Future research should investigate if this extent, based on the 2004 Mackenzie Valley Air Photo Project for example, is still accurate since the extent of point bars directly influences the calculations of the area underlain by near-surface permafrost.

The images analysed in this research only covered about $35 \%$ of the Delta. Therefore, future research should examine the use of fraction images derived from spectral unmixing of SPOT-5 data, for example, to map vegetation with Landsat since Landsat provides extensive coverage at low cost. Additional avenues for future research include the use of multi-temporal data to take advantage any phenologic differences 
between vegetation classes. Multi-temporal data usually improves the classification of wetlands and riparian vegetation (Ozesmi and Bauer 2002). Also, a combination of radar and optical data could also lead to more accurate classification of vegetation in the Delta, especially with the upcoming high-resolution Radarsat-2 (Bernier et al. 2003). Higher vegetation classification accuracies would improve the confidence of the conclusions presented in this thesis. 


\section{REFERENCES}

Bannari, A., Morin, D., and Bonn, F. 1995. A review of vegetation indices. Remote Sensing Reviews, 13: 95-120.

Bannari, A., Pacheco, A., Staenz, K., McNairn, H., and Omari, K. 2006. Estimating and mapping crop residues cover on agricultural lands using hyperspectral and IKONOS data. Remote Sensing of Environment, 104: 447-459.

Bastin, L. 1997. Comparison of fuzzy c-means classification, linear mixture modelling, and MLC probabilities as tools for unmixing coarse pixels. International Journal of Remote Sensing, 18: 3629-3648.

Berberoglu, S., Yilmaz, K.T., and Ozkan, C. 2004. Mapping and monitoring of coastal wetlands of Cukurova Delta in the Eastern Mediterranean region. Biodiversity and Conservation, 13: 615-633.

Bernier, M., Ghedira, H., Gauthier, Y., Magagi, R., Filion, R., de Sève, D., Ouarda, T., Villeneuve, J-P., and Buteau, P. 2003. Détection et classification de tourbières ombrotrophes du Québec à partir d'images RADARSAT-1. Canadian Journal of Remote Sensing, 29: 88-98.

Bigras, S.C. 1990. Hydrological regime of lakes in the Mackenzie Delta, Northwest Territories, Canada. Arctic and Alpine Research, 22: 163-174.

Boak, E.H., and Turner, I.L. 2005. Shoreline definition and detection: a review. Journal of Coastal Research, 21: 688-703, doi:10.2112/03-0071.1.

Bonham, C.D. 1989. Measurements for terrestrial vegetation. Wiley, New York. 338 pp.

Boyes, D.M. 1991. Using remote sensing and a geographic information system to model the potential effects of hydrological modification on vegetation patterns in the Mackenzie Delta. Unpublished M.Sc. thesis, University of Western Ontario.

Brooks, G.R. Streamflow in the Mackenzie valley. In The Physical Environment of the Mackenzie Valley, Northwest Territories: a Baseline for the Assessment of Environmental Change. Edited by L.D. Dyke and G.R. Brooks. Geological Survey of Canada, Bulletin 547, pp. 153-158.

Brown, R.J.E. 1966. Influence of vegetation on permafrost. In Proceedings of the International Conference on Permafrost. November 1963. Lafayette, Indiana. U.S. National Academy of Science and Natural Resources Council, Publication 1287. Washington, D.C., pp. 20-25. 
Brown, R.J.E. 1967. Permafrost in Canada. National Research Council of Canada, Publication 9769, and Geological Survey of Canada, Map 1246A, Ottawa, scale 1:7 603200 .

Brown, R.J.E. 1973. Permafrost. National Atlas of Canada, $4^{\text {th }}$ edition. Plate 11-12, scale $1: 15000000$.

Brown, R.J.E., and Péwé, T.L. 1973. Distribution of permafrost in North America and its relationship to the environment: a review, 1963-1973. In Proceedings, $2^{\text {nd }}$ International Conference on Permafrost, 13-28 July 1973, Yakutsk, U.S.S.R. North America Contribution, National Academy of Science Press, Washington, D.C., pp. 71-100.

Burgess, M.M., and Smith, S.L. 2000. Shallow ground temperatures. In The Physical Environment of the Mackenzie Valley, Northwest Territories: a Baseline for the Assessment of Environmental Change. Edited by L.D. Dyke and G.R. Brooks. Geological Survey of Canada, Bulletin 547, pp. 89-103.

Burn, C.R. 1995. The hydrologic regime of Mackenzie River and connection of "noclosure" lakes to distributary channels in the Mackenzie Delta, Northwest Territories. Canadian Journal of Earth Sciences, 32: 926-937.

Burn, C.R. 1997. Cryostratigraphy, paleogeography, and climate change during the early Holocene warm interval, western Arctic coast, Canada. Canadian Journal of Earth Sciences, 34: 912-925.

Burn, C.R. 1998. The response (1958-1997) of permafrost and near-surface ground temperatures to forest fires, Takhini River valley, southern Yukon Territory. Canadian Journal of Earth Sciences, 35: 184-199.

Burn, C.R. 2002a. Tundra lakes and permafrost, Richards Island, western arctic coast, Canada. Canadian Journal of Earth Sciences, 39: 1281-1298.

Burn, C.R. 2002b. Mackenzie Delta. In Natural History of the Western Arctic. Edited by S. Black and A. Fehr, Western Arctic Handbook Committee, pp. 24-29.

Burn, C. R., Barrow, E., and Bonsal, B. 2004. Climate change scenarios for the Mackenzie River Valley. In $57^{\text {th }}$ Canadian Geotechnical Conference, Quebec City, QC, Session 7A, pp. 2-8.

Carey, S.K., and Woo, M.K. 1999. Hydrology of two slopes in subarctic Yukon, Canada. Hydrological Processes, 13: 2549-2562.

Chen, D., and Stow, D. 2002. The effect of training strategies on supervised classification at different spatial resolutions. Photogrammetric Engineering and Remote Sensing, 68: $1155-1161$. 
Congalton, R.G. 1991. A review of assessing the accuracy of classifications of remotely sensed data. Remote Sensing of Environment, 37: 35-46.

Davidson, A., and Csillag, F. 2001. The influence of vegetation index and spatial resolution on a two-date remote sensing-derived relation to $\mathrm{C} 4$ species coverage. Remote Sensing of Environment, 75: 138-151.

Dillabaugh, K., and King, D.J. 2005. Wetland classification and productivity modelling with Ikonos. In Proceedings of the 15th Biennial Workshop on Color Photography and Videography in Resource Monitoring (American Society of Photogrammetry and Remote Sensing), Weslaco TX, October 2-4.

Duguay, C.R., Zhang, T., Leverington, D.W., and Romanovsky, V.E. 2005. Remote sensing of permafrost and seasonally frozen ground. In Remote Sensing in Northern Hydrology: Measuring Environmental Change. Edited by C.R. Duguay and A. Pietroniro. Geophysical Monograph 163, American Geophysical Union, Washington, D.C., pp. 91-118.

Dyke, L.D. 2000a. Shoreline permafrost along the Mackenzie River. In The Physical Environment of the Mackenzie Valley, Northwest Territories: a Baseline for the Assessment of Environmental Change. Edited by L.D. Dyke and G.R. Brooks. Geological Survey of Canada, Bulletin 547, pp. 143-151.

Dyke, L.D. 2000b. Climate of the Mackenzie River valley. In The Physical Environment of the Mackenzie Valley, Northwest Territories: a Baseline for the Assessment of Environmental Change. Edited by L.D. Dyke and G.R. Brooks. Geological Survey of Canada, Bulletin 547, pp. 21-30.

Eaton, A.K., Rouse, W.R., Lafleur, P.M., Marsh, P., and Blanken, P.D. 2001. Surface energy balance of the Western and Central Canadian Subarctic: Variations in the Energy Balance among Five Major Terrain Types. Journal of Climate, 14: 36923703.

Edwards Jr, T.C., Moisen, G.G., and Cutler, D.R. 1998. Assessing map accuracy in a remotely sensed, ecoregion-scale cover map. Remote Sensing of Environment, 63: 7383.

Ferrians, Jr, O.J., and Hobson, G.D. 1973. Mapping and predicting permafrost in North America: a review, 1963-1973. In Proceedings, $2^{\text {nd }}$ International Conference on Permafrost. North America Contribution. July 13-28, 1973. Yakutsk, U.S.S.R. National Academy of Science Press, Washington, D.C. pp. 479-498.

Foody, G.M. 2002. Status of land cover classification accuracy assessment. Remote Sensing of Environment, 80: 185-201. 
Foody, G.M., Lucas, R.M., Curran, P.J., and Honzak, M. 1996. Estimation of the areal extent of land cover classes that only occur at sub-pixel level. Canadian Journal of Remote Sensing, 22: 428-432.

Geobase. 2007. Landsat 7 orthorectified imagery over Canada. Website URL: http://www.geobase.ca/geobase/en/metadata.do?id=1583

Gill, D. 1972. The point bar environment in the Mackenzie River Delta. Canadian Journal of Earth Sciences, 9: 1382-1393.

Gill, D. 1973. A spatial correlation between plant distribution and unfrozen ground within a region of discontinuous permafrost. In Proceedings, $2^{\text {nd }}$ International Conference on Permafrost. North America Contribution. July 13-28, 1973. Yakutsk, U.S.S.R. National Academy of Science Press, Washington, D.C. pp. 105-113.

Goodrich, L.E. 1982. The influence of snow cover on the ground thermal regime. Canadian Geotechnical Journal, 19: 421-432.

Granberg, H.B. 1973. Indirect mapping of snow cover for permafrost prediction at Schefferville, Québec. In Proceedings, $2^{\text {nd }}$ International Conference on Permafrost, 13-28 July 1973, Yakutsk, U.S.S.R. North America Contribution, National Academy of Science Press, Washington, D.C., pp. 151-158.

Hall-Atkinson, C., and Smith, L.C. 2001. Delineation of delta ecozones using interferometric SAR phase coherence Mackenzie River Delta, N.W.T., Canada. Remote Sensing of Environment, 78: 229-238.

Halsey, L.A., Vitt, D.H., and Zoltai, S.C. 1995. Disequilibrium response of permafrost in boreal continental western Canada to climate change. Climatic Change, 30: 57-73.

Heginbottom, J.A. 2000. Permafrost distribution and ground ice in surficial materials. In The Physical Environment of the Mackenzie Valley, Northwest Territories: a Baseline for the Assessment of Environmental Change. Edited by L.D. Dyke and G.R. Brooks. Geological Survey of Canada, Bulletin 547, p. 31-39.

Heginbottom, J.A. 2002. Permafrost mapping: a review. Progress in Physical Geography, 26: 623-642.

Heginbottom, J.A., Dubreuil, M-A., and Harker, P.A. 1995. Canada - Permafrost. Ottawa, Canada: Natural Resources Canada, National Atlas of Canada, $5^{\text {th }}$ edition, Plate 2.1 (MCR No. 4177; scale 1:7 500 000) http:/atlas.gc.ca/site/english/maps/archives/5thedition/environment/land/mcr4177 (January 8, 2007) 
Hinzman, L.D., Kane, D.L., and Woo, M.K. 2005. Permafrost hydrology. In Encyclopedia of Hydrological Sciences. Edited by M.G. Anderson. John Wiley \& Sons, Ltd.

Hollingshead, G.W., Skjolingstad, L. and Rundquist, L.A. 1978. Permafrost beneath channels in the Mackenzie Delta, N.W.T., Canada. In Proceedings, $3^{\text {rd }}$ International Conference on Permafrost, July 1978, Edmonton, Alberta. National Research Council of Canada, Ottawa, pp. 151-158.

Jensen, J.R. 1996. Introductory digital image processing: a remote sensing perspective. Prentice-Hall, Upper Saddle River, N.J. 316 pp.

Johansen, K., and Phinn, S. 2006. Mapping structural parameters and species composition of riparian vegetation using IKONOS and Landsat ETM + data in Australian tropical savannahs. Photogrammetric Engineering and Remote Sensing, 72: 71-80.

Johnson, D., Kershaw, L., MacKinnon, A., and Pojar, J. 1995. Plants of the Western Boreal Forest and Aspen Parkland. Lone Pine Publishing and the Canadian Forest Service, Edmonton, AB. 392 pp.

Johnston, G.H., and Brown, R.J.E. 1964. Some observations of permafrost at an arctic lake in the Mackenzie Delta, N.W.T., Canada. Arctic, 17: 163-175.

Johnston, G.H., and Brown, R.J.E. 1965. Stratigraphy of the Mackenzie River Delta, Northwest Territories, Canada. National Research Council Canada, Division of Building Research, Paper 235.

Karunaratne, K.C., and Burn, C.R. 2004. Relations between air and surface temperature in discontinuous permafrost terrain near Mayo, Yukon Territory. Canadian Journal of Earth Sciences, 41: 1437-1451.

Kasischke, E.S., and Bourgeau-Chavez, L.L. 1997. Monitoring South Florida wetlands using ERS-1 SAR imagery. Photogrammetric Engineering and Remote Sensing, 63: 281-291.

Kavzoglu, T., and Mather, P.M. 2003. The use of back-propagating artificial neural networks in land cover classification. International Journal of Remote Sensing, 24: 4907-4938.

Kettles, I.M., Tarnocai, C., and Bauke, S.D. 1997. Predicted permafrost distribution in Canada under a climate warming scenario. Current Research 1997-E, Geological Survey of Canada, p. 109-115.

Kokelj, S.V., and Burn, C.R. 2004. Tilt of spruce trees near ice wedges, Mackenzie Delta, Northwest Territories, Canada. Arctic, Antarctic and Alpine Research, 36: 615-623. 
Kokelj, S.V., and Burn, C.R. 2005a. Geochemistry of the active layer and near-surface permafrost, Mackenzie delta region, Northwest Territories, Canada. Canadian Journal of Earth Sciences, 42: 37-48.

Kokelj, S.V., and Burn, C.R. 2005b. Near-surface ground ice in sediments of the Mackenzie Delta, Northwest Territories, Canada. Permafrost and Periglacial Processes, 16: 291-303.

Laidler, G.J., and Treitz, P. 2003. Biophysical remote sensing of arctic environments. Progress in Physical Geography, 27: 44-68.

Lévesque, J., and King, D.J. 2003. Spatial analysis of radiometric fractions from highresolution multispectral imagery for modelling individual tree crown and forest canopy structure and health. Remote Sensing of Environment, 84: 589-602.

Leverington, D.W. 1995. A field survey of late-summer depths to frozen ground at two study areas near Mayo, Yukon Territory, Canada. Permafrost and Periglacial Processes, 6: 373-379.

Leverington, D.W., and Duguay, C.R. 1997. A neural network method to determine the presence or absence of permafrost near Mayo, Yukon Territory, Canada. Permafrost and Periglacial Processes, 8: 205-215.

Lewkowicz, A.G., and Ednie, M. 2004. Probability mapping of mountain permafrost using the BTS method, Wolf Creek, Yukon Territory, Canada. Permafrost and Periglacial Processes, 15: 67-80.

Lewkowicz, A.G., and Harris, C. 2005. Frequency and magnitude of active-layer detachment failures in discontinuous and continuous permafrost, northern Canada. Permafrost and Periglacial Processes, 16: 115-130.

Lillesand, T.M., Kiefer, R.W., and Chipman, J.W. 2004. Remote sensing and image interpretation. John Wiley \& Sons Inc., New York. 763 pp.

Liu, C., Frazier, P., and Kumar, L. 2007. Comparative assessment of the measures of thematic classification accuracy. Remote Sensing of Environment, 107: 606-616.

Lu, D., and Weng, Q. 2007. A survey of image classification methods and techniques for improving classification performance. International Journal of Remote Sensing, 28: 823-870.

Luthin, J.N., and Guymon, G.L. 1974. Soil moisture-vegetation-temperature relationships in central Alaska. Journal of Hydrology, 23: 233-246. 
Ma, Z., Hart, M.M., and Redmond, R.L. 2001. Mapping vegetation across large geographic areas: integration of remote sensing and GIS to classify multiresource data. Photogrammetric Engineering and Remote Sensing, 67: 295-307.

Mackay, J.R. 1962. Pingos of the Pleistocene Mackenzie delta area. Geographical Bulletin, 18: 21-63.

Mackay, J.R. 1963. The Mackenzie Delta area, N.W.T., Canada. Department of Mines and Technical Surveys, Geographical Branch, Memoir 8.

Mackay, J.R. 1986. The first 7 years (1978 - 1985) of ice wedge growth, Illisarvik experimental drained lake site, western Arctic coast. Canadian Journal of Earth Sciences, 23: 1782-1795.

Mackay, J.R. 1995. Active-layer changes (1968-1993) following the forest-tundra fire near Inuvik, N.W.T., Canada. Arctic and Alpine Research, 27: 323-336.

Mackay, J.R., and Burn, C.R. 2002. The first 20 years (1978-1979 to 1998-1999) of active-layer development, Illisarvik experimental drained lake site, western Arctic coast, Canada. Canadian Journal of Earth Sciences, 39: 1657-1674.

Mackay, J.R., and MacKay, D.K. 1974. Snow cover and ground temperatures, Garry Island, N.W.T. Arctic, 27: 287-296.

Marsh, P., and Hey, M. 1991. Spatial variations in the spring flooding of Mackenzie Delta lakes. In Mackenzie Delta, Environmental interactions and implications of development. Proceedings of the Workshop on the Mackenzie Delta, 17-18 October 1989, Saskatoon, Saskatchewan. Edited by P. Marsh and C.S.L. Ommanney. National Hydrology Research Institute, Symposium No. 4, pp. 9-17.

Marsh, P., and Schmidt, T. 1993. Influence of a Beaufort Sea storm surge on channel levels in the Mackenzie Delta. Arctic, 46: 35-41.

McCoy, R.M. 2005. Field methods in remote sensing. The Guilford Press, New York. 159 pp.

Mills, H., Cutler, M.E.J., and Fairbairn, D. 2006. Artificial neural networks for mapping regional-scale upland vegetation from high spatial resolution imagery. International Journal of Remote Sensing, 27: 2177-2195.

Morrissey, L.A., Strong, L.L., and Card, D.H. 1986. Mapping permafrost in the boreal forest with Thematic Mapper satellite data. Photogrammetric Engineering and Remote Sensing, 52: 1513-1520.

Mueller-Dombois, D., and Ellenberg, H. 1974. Aims and methods of vegetation ecology. John Wiley and Sons, New York. 547 pp. 
National Vegetation Classification Standard. 1997. National Spatial Data Infrastructure, Vegetation subcommittee, Federal Geographic Data Committee, June 1997.

Nelson, F.E., Shiklomanov, N.I., Mueller, G.R., Hinkel, K.M., Walker, D.A., and Bockheim, J.G. 1997. Estimating active-layer thickness over a large region: Kuparuk River Basin, Alaska, USA. Arctic and Alpine Research, 29: 367-378.

Olthof, I., and Fraser, R.H. 2007. Mapping northern land cover fractions using Landsat ETM+. Remote Sensing of Environment, 107: 496-509.

Ozesmi, S.L., and Bauer, M.E. 2002. Satellite remote sensing of wetlands. Wetlands Ecology and Management, 10: 381-402.

Pasher, J., King, D.J., and Lindsay, K. 2007. Modelling and mapping potential hooded warbler (Wilsonia citrina) habitat using remotely sensed imagery. Remote Sensing of Environment, 107: 471-483.

Pearce, C.M. 1986. The distribution and ecology of the shoreline vegetation on the Mackenzie Delta, N.W.T. Unpublished Ph.D. thesis, University of Calgary, Alberta.

Pearce, C.M. 1994. Overbank sedimentation patterns on the Mackenzie Delta, Northwest Territories: Volume 2 (1993-1994). Inland Waters Directorate, Environment Canada: Yellowknife; IWD-NOGAP Project C.11.4: 57 pp.

Pearce, C.M. 1998. Vegetation patterns and environmental relationships in an Arctic riparian wetland. In Ecology of Wetlands and Associated Systems. Edited by S.K. Majumdar, E.W. Miller, and F.J. Brenner. The Pennsylvania Academy of Science, pp. 258-280.

Peddle, D.R., and Franklin, S.E. 1993. Classification of permafrost active-layer depth from remotely sensed and topographic evidence. Remote Sensing of Environment, 44: $67-80$.

Péwé, T.L. 1983. Alpine permafrost in the contiguous United States: a review. Arctic and Alpine Research, 15: 145-156.

Pisaric, M.F.J., Carey, S.K., Kokelj, S.V., and Youngblut, D. 2007. Anomalous $20^{\text {th }}$ century tree growth, Mackenzie Delta, Northwest Territories, Canada. Geophysical Research Letters, 34, L05714, doi:10.1029/2006GL029139.

Puissant, A., Hirsch, J., and Weber, C. 2005. The utility of texture analysis to improve per-pixel classification for high to very high spatial resolution imagery. International Journal of Remote Sensing, 26: 733-745.

Riedel, S.M., Epstein, H.E., Walker, D.A., Richardson, D.L., Calef, M.P., Edwards, E., and Moody, A. 2005. Spatial and temporal heterogeneity of vegetation properties 
among four tundra plant communities at Ivotuk, Alaska, USA. Arctic, Antarctic and Alpine Research, 37: 25-33.

Rouse, W.R. 1993. Northern climates. In Canada's Cold Environments. Edited by H.M. French and O. Slaymaker. McGill-Queen's University Press, Montreal, pp. 65-92.

Serreze, M.C., Walsh, J.E., Chapin, F.S., III, Osterkamp, T., Dyurgerov, M., Romanovsky, V., Oechel, W.C., Morison, J., Zhang, T., and Barry, R.G. 2000. Observational evidence of recent change in the northern high-latitude environment. Climatic Change, 46: 159-207.

Shippert, M.M., Walker, D.A., Auerbach, N.A., and Lewis, B.E. 1995. Biomass and leafarea index maps derived from SPOT images for Toolik Lake and Imnavait Creek areas, Alaska. Polar Record, 31: 147-154.

Shur, Y.L., and Jorgenson, M.T. 2007. Patterns of permafrost formation and degradation in relation to climate and ecosystems. Permafrost and Periglacial Processes, 18: 719.

Smith, M.W. 1975. Microclimatic influences on ground temperatures and permafrost distribution, Mackenzie Delta, Northwest Territories. Canadian Journal of Earth Sciences, 12: 1421-1438.

Smith, M.W. 1976. Permafrost in the Mackenzie Delta, Northwest Territories. Geological Survey of Canada, Paper 75-28.

Smith, M.W., and Hwang, C.T. 1973. Thermal disturbance due to channel shifting, Mackenzie Delta, N.W.T., Canada. In Proceedings, $2^{\text {nd }}$ International Conference on Permafrost, 13-28 July 1973, Yakutsk, U.S.S.R. North America Contribution, National Academy of Science Press, Washington, D.C., pp. 51-60.

Smith, S.L., Burgess, M.M., and Heginbottom, J.A. 2001. Permafrost in Canada, a challenge to northern development. In $A$ synthesis of geological hazards in Canada. Edited by G.R. Brooks. Geological Survey of Canada, Bulletin 548, p. 241-264.

Smith, S.L., Burgess, M.M., Riseborough, D., and Nixon, F.M. 2005. Recent trends from Canadian permafrost thermal monitoring network sites. Permafrost and Periglacial Processes, 16: 19-30.

Song, S., Woodcock, C.E., Seto, K.C., Lenney, M.P., and Macomber, S.A. 2001. Classification and change detection using Landsat TM data: When and how to correct atmospheric effects? Remote Sensing of Environment, 75: 230-244.

Stehman, S.V., Arora, M.K., Kasetkasem, T., and Varshney, P.K. 2007. Estimation of fuzzy error matrix accuracy measures under stratified random sampling. Photogrammetric Engineering and Remote Sensing, 73: 165-173. 
Stow, D.A., Burns, B.H., and Hope, A.S. 1993. Spectral, spatial and temporal characteristics of Arctic tundra reflectance. International Journal of Remote Sensing, 14: $2445-2462$.

Sturm, M., McFadden, J.P., Liston, G.E., Chapin III, F.S., Racine, C.H., and Holmgren, J. 2001. Snow-shrub interactions in Arctic tundra: a hypothesis with climatic implications. Journal of Climate, 14: 336-344.

Timoney, K.P., La Roi, G.H., Zoltai, S.C., and Robinson, A.L. 1992. The High Subarctic forest-tundra of northwestern Canada: position, width, and vegetation gradients in relation to climate. Arctic, 45: 1-9.

Tso, B., and Mather, P.M. 2001. Classification methods for remotely sensed data. Taylor \& Francis, London. 332 pp.

van Everdingen, R.O. (Ed.) 1998. Multi-language Glossary of Permafrost and Related Ground-Ice Terms. University of Calgary, Calgary, Alberta, Canada.

Viereck, L.A. 1973. Ecological effects of river flooding and forest fires on permafrost in the taiga of Alaska. In Proceedings, $2^{\text {nd }}$ International Conference on Permafrost, 1328 July 1973, Yakutsk, U.S.S.R. North America Contribution, National Academy of Science Press, Washington, D.C., pp. 60-67.

Vitt, D.H., and Halsey, L.A. 1994. The bog landforms of continental western Canada in relation to climate and permafrost patterns. Arctic and Alpine Research, 26: 1-13.

Walker, D.A. 2000. Hierarchical subdivision of Arctic tundra based on vegetation response to climate, parent material and topography. Global Change Biology, 6: 1934.

Walker, D.A., Epstein, H.E., Jia, G.J., Balser, A., Copass, C., Edwards, E.J., Gould, W.A., Hollingsworth, J., Knudson, J., Maier, H.A., Moody, A., and Raynolds, M.K. 2003. Phytomass, LAI, and NDVI in northern Alaska: Relationships to summer warmth, soil $\mathrm{pH}$, plant functional types, and extrapolation to circumpolar Arctic. Journal of Geophysical Research, 108 (D2), 8169, doi:10.1029/2001JD000986.

Williams, D.J., and Burn, C.R. 1996. Surficial characteristics associated with the occurrence of permafrost near Mayo, central Yukon Territory, Canada. Permafrost and Periglacial Processes, 7: 193-206.

Williams, P.J., and Smith, M.W. 1989. The frozen earth, fundamentals of geocryology. Cambridge University Press, Cambridge, UK.

Woodcock, C.E., and Strahler, A.H. 1987. The factor of scale in remote sensing. Remote Sensing of Environment, 21: 311-332. 
Wulder, M.A. 2005. Multivariate statistics - Multicollinearity and Singularity. Website URL: http://www.pfc.forestry.ca/profiles/wulder/mvstats/multicol_e.html

Wulder, M.A., Franklin, S.E., White, J.C., Linke, J., and Magnussen, S. 2006. An accuracy assessment framework for large-area land cover classification procedure derived from medium-resolution satellite data. International Journal of Remote Sensing, 27: 663-683.

Xavier, A.C., and Vettorazzi, C.A. 2004. Mapping leaf area index through spectral vegetation indices in a subtropical watershed. International Journal of Remote Sensing, 25: 1661-1672.

Zhang, T., Barry, R.G., Knowles, K., Heginbottom, J.A., and Brown, J. 1999. Statistics and characteristics of permafrost and ground-ice distribution in the Northern Hemisphere. Polar Geography, 23: 132-154. 